\title{
6. CENOZOIC GLACIAL RECORD OF THE PRYDZ BAY CONTINENTAL SHELF, EAST ANTARCTICA ${ }^{1}$
}

\author{
Michael J. Hambrey, ${ }^{2,3}$ Werner U. Ehrmann, ${ }^{2}$ and Birger Larsen ${ }^{4}$
}

\begin{abstract}
Drilling was undertaken at five sites (739-743) on ODP Leg 119 on a transect across the continental shelf of Prydz Bay, East Antarctica, to elucidate the long-term glacial history of the area and to examine the importance of the area with respect to the development of the East Antarctic ice sheet as a whole. In addition to providing a record of glaciation spanning $36 \mathrm{~m} . \mathrm{y}$. or more, Leg 119 has provided information concerning the development of a continental margin under the prolonged influence of a major ice sheet. This has allowed the development of a sedimentary model that may be applicable not only to other parts of the Antarctic continental margin, but also to northern high-latitude continental shelves.
\end{abstract}

The cored glacial sedimentary record in Prydz Bay consists of three major sequences, dominated by diamictite:

1. An upper flat-lying sequence that ranges in thickness from a few meters in inner and western Prydz Bay to nearly $250 \mathrm{~m}$ in the outer or eastern parts of the bay. The uppermost few meters consist of Holocene diatom ooze and diatomaceous mud with a minor ice-rafted component overlying diamicton and diamictite of late Miocene to Quaternary age. The diamictite is mainly massive, but stratified varieties and minor mudstone and diatomite also occur.

2. An upper prograding sequence cored at Sites 739 and 743 , unconformly below the flat-lying sequence. This consists of a relatively steep $\left(4^{\circ}\right.$ inclination) prograding wedge with a number of discrete sedimentary packages. At Sites 739 and 743 the sequence is dominated by massive and stratified diamictite, some of which shows evidence of slumping and minor debris flowage.

3. A lower, more gently inclined, prograding sequence lies unconformably below the flat-lying sequence at Site 742 and the upper prograding sequence at Site 739. This extends to the base of both sites, to 316 and 487 mbsf, respectively. It is dominated by massive, relatively clast-poor diamictite which is kaolinite-rich, light in color, and contains sporadic carbonate-cemented layers. The lower part of Site 742 includes well-stratified diamictites and very poorly sorted mudstones. The base of this site has indications of large-scale soft-sediment deformation and probably represents proximity to the base of the glacial sequence.

Facies analysis of the Prydz Bay glacial sequence indicates a range of depositional environments. Massive diamictite is interpreted largely as waterlain till, deposited close to the grounding line of a floating glacier margin, although basal till and debris flow facies are also present. Weakly stratified diamictite is interpreted as having formed close to or under the floating ice margin and influenced by the input of marine diatomaceous sediment (proximal glaciomarine setting). Well-stratified diamictite has a stronger marine input, being more diatom-rich, and probably represents a proximal-distal glaciomarine sediment with the glaciogenic component being supplied by icebergs. Other facies include a variety of mudstones and diatom-rich sediments of marine origin, in which an ice-rafted component is still significant. None of the recovered sediments are devoid of a glacial influence.

The overall depositional setting of the prograding sequence is one in which the grounded ice margin is situated close to the shelf edge. Progradation was achieved primarily by deposition of waterlain till. The flat-lying sequence illustrates a complex sequence of advances and retreats across the outer part of the shelf, with intermittent phases of ice loading and erosion.

The glacial chronology is based largely on diatom stratigraphy, which has limited resolution. It appears that ice reached the paleoshelf break by earliest Oligocene, suggesting full-scale development of the East Antarctic ice sheet by that time. The ice sheet probably dominated the continental margin for much of Oligocene to middle Miocene time. Retreat, but not total withdrawal of the ice sheet, took place in late Miocene to mid-Pliocene time. The late Pliocene to Pleistocene was characterized by further advances across, and progradation of, the continental shelf. Holocene time has been characterized by reduced glacial conditions and a limited influence of glacial processes on sedimentation.

\section{INTRODUCTION}

On Leg 119 of the Ocean Drilling Program (ODP) we drilled 11 sites on the Kerguelen Plateau in the southern Indian Ocean and on the continental shelf of East Antarctica in Prydz Bay,

\footnotetext{
${ }^{1}$ Barron, J., Larsen, B., et al., 1991. Proc. ODP, Sci. Results, 119. College Station, TX (Ocean Drilling Program).

2 Alfred-Wegener-Institut für Polar-und Meeresforschung, Columbusstrasse, D-2850 Bremerhaven, Federal Republic of Germany.

${ }^{3}$ Present address: Scott Polar Research Institute, University of Cambridge, Lensfield Road, Cambridge CB2 1ER, United Kingdom.

${ }^{4}$ Danmarks Geologiske Undersøgelse, Thoravej 8, DK-2400 København NV, Denmark.
}

between December 1987 and February 1988. A range of studies has been undertaken on the five drill cores obtained on a profile across the Prydz Bay continental shelf (Fig. 1), with a view to elucidating the long-term history of the East Antarctic ice sheet. In particular we have (1) addressed the problem of the timing of the onset of glaciation at sea level and the growth and fluctuations of the ice sheet from Oligocene through Neogene and Quaternary time, (2) investigated the history of glacial erosion of the shelf, which is necessary for determining ice volume changes, (3) documented other changes in the shelf environment during periods of lesser ice cover, providing indications of climatic change, and (4) developed a sedimentological model for the development of a high-latitude continental shelf domi- 


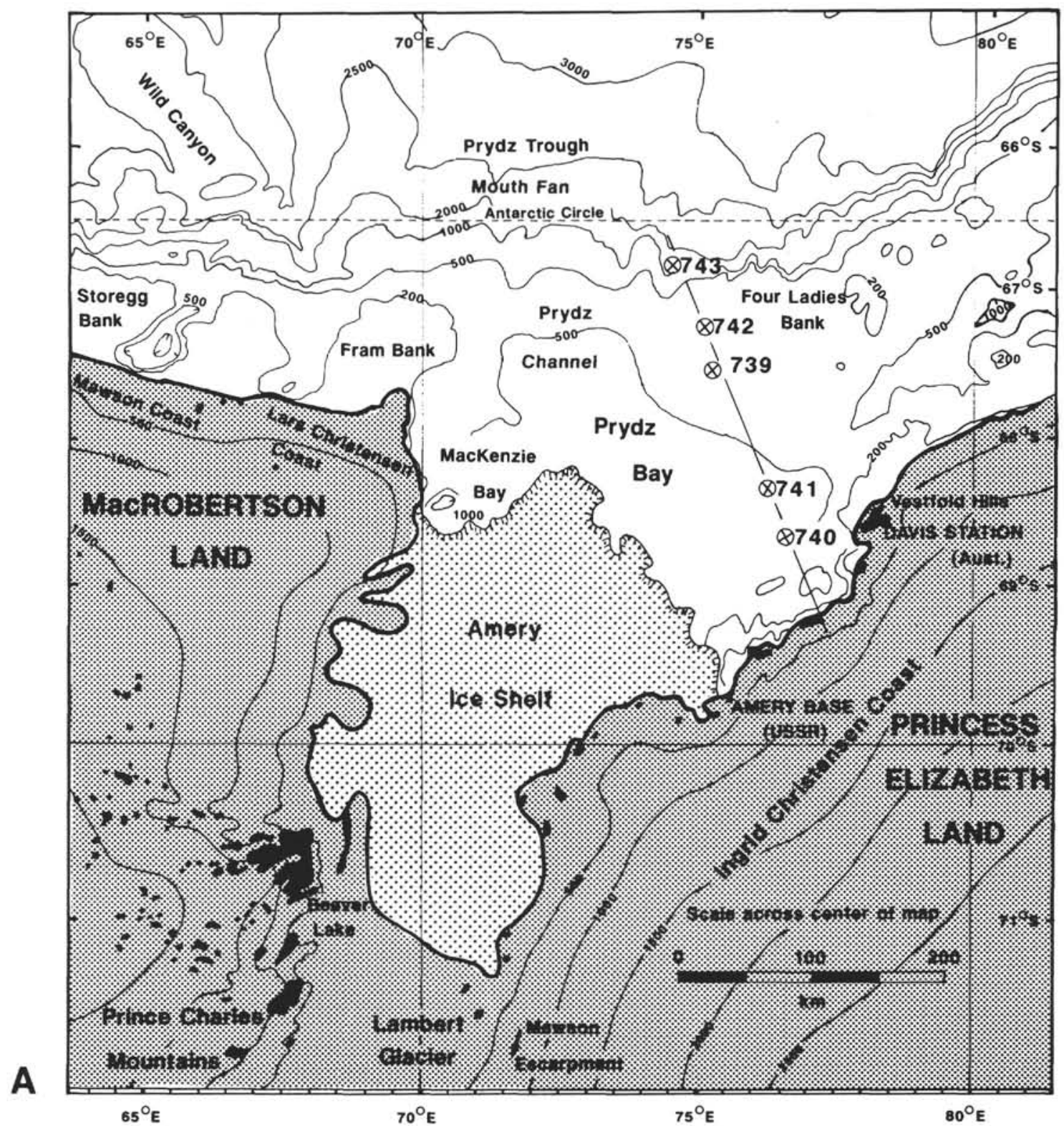

Figure 1. A. Bathymetric setting of the five Prydz Bay drill sites, 739-743. B. Geological cross section through the drill sites, based on seismic and drillhole data combined (after Hambrey et al., 1989b).

nated by glacial deposition. This study is the first to be concerned with the development of a high-latitude continental shelf under the prolonged influence of glaciation, by combining deepdrilling results on a profile from the inner shelf to the continental slope with a comprehensive seismic data set.

\section{Glacial History of Antarctica: Previous Work}

\section{The Deep-sea Record}

Several workers have attempted to document the Antarctic ice sheet record indirectly from the $\delta^{18} \mathrm{O}$ isotope curve recorded by planktonic and benthic foraminifers in deep-sea sediments. However, different interpretations of the same records have been proposed. Shackleton and Kennett's (1975) isotope record was interpreted as indicating significant high-latitude cooling at the Eocene/Oligocene boundary, but also that the Antarctic ice sheet did not grow to continental dimensions until mid-Miocene time. More detailed sampling of deep-sea cores subsequently suggested that substantial ice existed a number of times during the Oligocene Epoch, with the most marked ice build-up at the Eocene/Oligocene boundary (Shackleton 1986). In contrast, Matthews and Poore (1980) suggested that there was already a significant build up of ice by Eocene time, and that substantial ice may have existed as early as Cretaceous time. Another viewpoint has been that the ice sheet existed in early Oligocene time, but that the rest of Oligocene and early Miocene time was possibly ice-free (Miller et al., 1987).

Deep-sea sediments have also provided a record of ice rafting from Antarctica. The earliest unequivocal evidence came from ODP Leg 113 in the Weddell Sea, where ice-rafted clasts were observed in lower Oligocene sediments (Ocean Drilling Program Leg 113 Shipboard Scientific Party, 1987; Barker, Kennett, et al., 1988), as subsequently confirmed by Leg 119 at the Kerguelen Plateau (Ocean Drilling Program Leg 119 Shipboard Scientific Party, 1988; Barron, Larsen, et al., 1989; Ehrmann, this volume). 


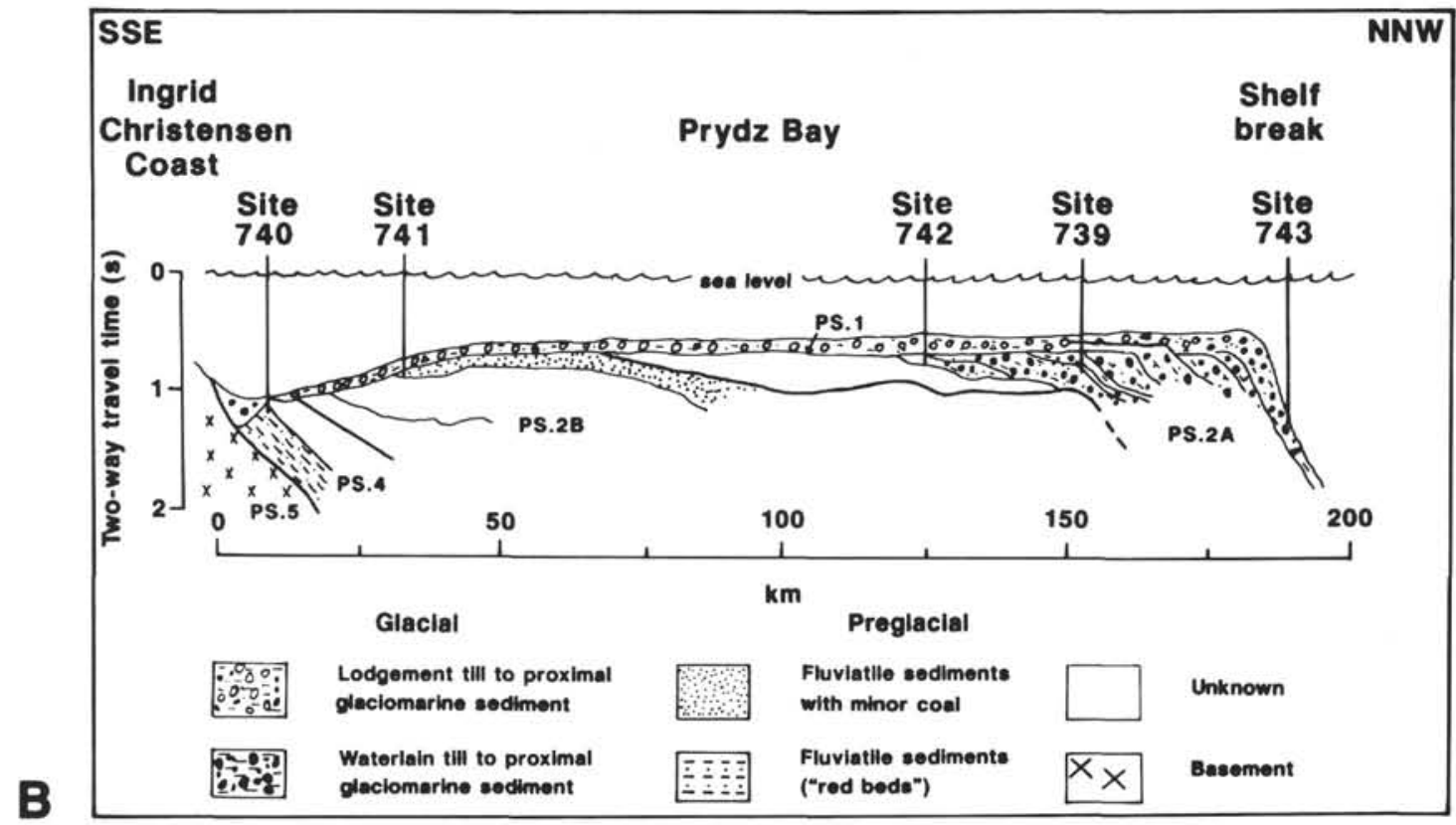

Figure 1 (continued).

\section{The Continental Shelf and Terrestrial Record}

Drilling on the continental shelf of Antarctica was expected to show a more direct record of glaciation, albeit one that was less complete than the deep-sea record. However, a series of drilling projects since 1973 has progressively pushed back the known start of the onset of large-scale glaciation. Furthermore, onshore investigations have provided a long record of glaciation that may have more than just local significance.

Deep-Sea Drilling Project Leg 28 drilled four holes on the Ross continental shelf, and at Site 270 passed through upper Oligocene glaciomarine sediments into gneissic basement (Hayes, Frakes, et al., 1975). This was clear evidence that ice reached the coast by at least $25 \mathrm{Ma}$, when previously ice cover had been more or less equated with the Quaternary period. However, the question as to whether this represented local, as opposed to continental, glaciation was not resolved.

The next phase of drilling, the Dry Valleys Drilling Project, took place mainly on land bordering the western Ross Sea. Although this project achieved good resolution of the PliocenePleistocene record, older sediments were not recovered (McGinnis, 1981).

The first of a series of sea ice-based drilling projects in western McMurdo Sound by the New Zealand Antarctic Research Programme began in 1979. The drill hole MSSTS-1 reached a depth of $227 \mathrm{~m}$ below seafloor (mbsf), and took the glacial record further back in Oligocene time, to about $32 \mathrm{Ma}$, but still the base of the glacial sequence was not reached (Barrett, 1986; Barrett et al., 1987). MSSTS-1 was succeeded by CIROS drilling in the same area. In 1984 CIROS- 2 was drilled, close to the floating snout of the Ferrar Glacier. A complex Pliocene-Quaternary record of ice advances and retreats, involving both local Transantarctic Mountain and Ross Ice Shelf ice was recorded (Barrett and Scientific Staff, 1985; Barrett and Hambrey, in press).

CIROS-1 was drilled in late 1986 near to MSSTS-1, and recovered the longest sediment core to date from Antarctica, penetrating to 702 mbsf, with a remarkable $98 \%$ recovery. This pushed back the glacial record at sea level even further, to earliest Oligocene time, or around $36 \mathrm{Ma}$ ago, but still the base of the glacial sequence was not reached. The core yielded a record of Oligocene-Miocene glacial advances and retreats that will serve as a reference for a long time to come. However, the proximity of the Transantarctic Mountains to this drill site begs the question as to whether the glaciers that reached the coast in this region were local, at least for early Oligocene time, and related to tectonic uplift of those mountains (Barrett et al., 1989; Barrett et al., in press).

Onshore investigations of a well-exposed glaciomarine sequence in the most temperate part of Antarctica, namely King George Island in the South Shetland Islands near the northern tip of the Antarctic Peninsula, have yielded a record of glaciation relating to the development of ice over West Antarctica. Several glaciations have taken place since Eocene time in this sector of Antarctica. The earliest, considered to be a local glaciation from the nearby mountains of the Antarctic Peninsula, has been provisionally dated as mid-Paleocene to early Eocene (Birkenmajer, 1988). The first major West Antarctic glaciation, and possibly the most extensive of all Cenozoic glaciations, is recorded by the Polonez Formation (Birkenmajer, 1987; Porebski and Gradzinski, 1987); this is now considered to be of early Oligocene age (Gadzdzicki, 1989). However, the record from King George Island has proved difficult to match with paleoclimatic changes inferred from the deep-sea isotope record.

The conflicting interpretations from the deep-sea isotope record concerning earlier ice cover over Antarctica have not been resolved by work on the continent. The presence of material rafted by ice of unknown origin in Early Cretaceous strata in Australia (which then was linked to Antarctica) has been used to tentatively suggest that the polar region had an ice cover at this time (Frakes and Francis, 1988). However, this is contradicted by the evidence that the Antarctic Peninsula was well vegetated, humid and warm in early Cretaceous time (Jefferson, 1982).

ODP Leg 119 to Prydz Bay was considered crucial to establishing the onset of continent-wide glaciation. The bay lies at the mouth of a sediment-filled graben structure that is related to the break-up of Gondwana (Cooper, et al, this volume). This graben may have existed since late Mesozoic time (Federov, et al., 1982b) or even Paleozoic time (Stagg, 1985). A large volume 
of East Antarctic ice drains through the graben (Hambrey, this volume). Thus, Prydz Bay was expected to reveal one of the earliest indications of ice reaching the coast. Although this question has not been finally resolved, drilling has confirmed that, according to paleontological evidence, continent-wide glaciation was already in evidence by earliest Oligocene time and possibly in the middle to late Eocene. Furthermore, the five holes drilled provide for the first time a detailed transect across a continental margin that has been dominated by glacial deposition for a geologically significant period of time (35-40 m.y.).

\section{Deposition on Glacially Dominated High-Latitude Continental Shelves: Current Knowledge}

Alhough processes and patterns of sedimentation have been examined extensively at the margins of terrestrial ice masses, the problems of access to the glaciomarine environment have restricted knowledge of processes at the margins of ice shelves and other tidewater glaciers.

The publication of several review papers in recent years demonstrates the importance today of glaciomarine processes on high-latitude continental shelves (e.g., Andrews and Matsch, 1983; Molnia, 1983; Syvitski and Skei, 1983; Elverhøi, 1984; Bornhold and Guilcher, 1984; Dowdeswell, 1987; Powell and Molnia, 1989; Powell and Elverhøi, 1989). Early attempts at developing a depositional model for the glaciomarine environment were founded on little field data (Carey and Ahmad, 1961). Recent models are founded on a much better, though still inadequate data base. Facies models based on sedimentological parameters include those of Powell $(1981,1983,1984)$, Boulton and Deynoux (1981), Eyles et al. (1983, 1985), Elverhøi and Roaldset (1983), Elverhøi et al. (1983), Anderson et al. (1983), Molnia (1983), Elverhøi (1984), and King et al. (1987). Models emphasising glaciological principals are fewer (Drewry and Cooper, 1981; Drewry, 1986; Dowdeswell and Dowdeswell, 1989), and the data set is still inadequate for the wide range of glaciological conditions at the margins of marine ice masses. In particular our understanding is limited concerning the modes of debris transport into the marine environment, the thermal regime of the transporting glaciers, the rates of sediment supply, the importance of meltwater, the role of water depth, and ocean currents, the character of sediments deposited beneath floating ice and its modification by marine processes, and the role of sea ice. We also have little perception of the geometry of glaciomarine facies or facies architecture, particularly on ice sheetdominated shelves, such as prevailed during deposition of the middle and late Tertiary sequence in Prydz Bay.

In recent years, to address these questions, sedimentological studies have been undertaken in a variety of glacial settings around Antarctica, based on deep and shallow coring, mainly at widely separated sampling sites. Of relevance to this investigation are the following:

1. Inner to outer continental shelf sedimentation, the most comprehensive data sets being those of Anderson (1983), Anderson et al. (1980b, 1988c), Cooper and Davey (1987), Domack et al. (1980), Wright and Anderson (1982), Domack (1988), Fütterer and Melles (in press), and Kennedy and Anderson (1989).

2. The margin of a large ice shelf (the Ronne-Filchner), by Elverhøi and Roaldset (1983), Haase (1986), and Melles (1987).

3. Outer shelf and continental slope sedimentation (Antarctic Peninsula), by Larter and Barker (1989), Anderson et al. (1979), Grobe (1986a, 1986b), and Fütterer et al. (1988).

Reviews discussing the factors influencing glaciomarine sedimentation have been outlined by Alley et al. (1989), Anderson (1983), Anderson and Molnia (1989), Drewry and Cooper (1981), Drewry (1986), Dowdeswell (1987), and Powell (1984).

\section{GEOGRAPHICAL AND GEOLOGICAL SETTING}

Prydz Bay is an embayment in the East Antarctic craton facing the Indian Ocean (about $76^{\circ} \mathrm{E}, 68^{\circ} \mathrm{S}$ ). The continental shelf of Prydz Bay has built out from the mouth of the Lambert Graben, a major long-lived tectonic feature that is believed to have existed since Permian time (Fedorov et al., 1982a, 1982b; Stagg, 1985), and therefore provided the major drainage route for the transport of the sediments that make up the shelf.

The graben is occupied by the Lambert Glacier and its floating seaward extension, the Amery Ice Shelf. The bulk of the ice rises in an interior basin, backed by the 3000-m-high Gamburtsev Subglacial Mountains, which are entirely buried by ice, although in places the ice cover is only a few hundred meters thick (Swithinbank, 1988). This interior basin is drained by the Lambert Glacier and covers $902,000 \mathrm{~km}^{2}$, making this system the second largest ice stream in Antarctica after the Byrd Glacier (McIntyre, 1985). This interior basin represents about a tenth of the East Antarctic Ice Sheet by area. The lower part of the Lambert Glacier and the Amery Ice Shelf are joined by several major tributaries, especially from the Prince Charles Mountains on the western side, almost doubling the total area of the glacier basin.

The subglacial floor of the Lambert Graben lies below sea level for several hundred kilometers from the ice shelf edge; for example, $600 \mathrm{~km}$ from the edge the floor is $840 \mathrm{~m}$ below sea level (mbsl). The graben thus represents an ice-filled fjord and is filled by ice to a depth of $2500 \mathrm{~m}$. Thus the true depth of the graben valley in the region of the Mawson Escarpment is some $3000 \mathrm{~m}$, and its width is at least $50 \mathrm{~km}$ (Swithinbank, 1988) (see Hambrey, this volume).

The Lambert Graben is formed largely in Precambrian metamorphic basement. The graben is defined by deep faults, according to seismic soundings, and magnetic data reveal bedrock depression $5 \mathrm{~km}$ or more deep in the graben filled with nonmagnetic rocks (Fedorov et al., 1982a). These sediments probably date back to Permian time, as suggested by an exposed outlier of sediments of this age in the Beaver Lake area of the Prince Charles Mountains (Fedorov et al., 1982a; Trail and McLeod, 1969).

Bordering the outer arms of Prydz Bay, coastal strips of bedrock consisting of basement rocks are locally exposed. Most of the subglacial topography inland from the coast is above sea level, and the ice cover increases gradually inland to $3000 \mathrm{~m}$. However, in comparison to the Lambert-Amery system, this ice forms a much less important component of discharge into the bay. Nevertheless, the entire glacierized area draining into Prydz Bay, although very poorly defined, represents about a fifth of the area of the East Antarctic ice sheet.

The 200-km-wide continental shelf in Prydz Bay, in general, is deep compared with shelf areas outside Antarctica. Distinctive features are the deep ice-eroded marginal channels cutting into the sediments a short distance from the edge of the basement outcrops (Fig. 1). These channels attain depths of more than $1000 \mathrm{~m}$. Depths at the shelf edge are less than $500 \mathrm{~m}$. Particularly important shallow areas are represented by the banks. For example, the Four Ladies Bank on the outer shelf rises to less than $200 \mathrm{mbsl}$. The wide transverse Prydz Channel extends north-northwest from the Amery Ice Shelf, forming the topographic continuation of the ice-filled Lambert Graben valley. A northward arcuate convex projection of the continental slope observed in front of the Prydz Channel resembles a "trough mouth fan" as defined by Vorren et al. (1988). Overall, the shelf slopes landward. On a local scale, the seafloor is mostly smooth except for the extensive iceberg gouge marks up to several meters deep on the banks, and presumably also in the nearshore basement areas. Many other parts of the East Antarctic continental shelf have similar characteristics. 
The geological structure of the continental shelf is known from magnetic (Ivanov, 1983) and seismic-reflection surveys (Stagg, 1985; Mizukoshi et al., 1988; Cooper et al., this volume). Several longitudinal profiles were made across the shelf at the mouth of the broad Prydz Channel. The acoustic character of the shelf was found to be highly variable. The main seismic stratigraphic sequence consists of reflectors dipping regionally seaward in the inner and outer parts of the shelf, but lying in an irregular but nearly flat manner in between (Fig. 1). In the inner shelf the dipping sequences are uniformly layered, whereas those in the outer shelf comprise more steeply dipping wedges of prograding strata. The stratigraphically lower part of the prograding sequence has less steeply dipping strata. The upper part of the prograding sequence was eroded and truncated and now is overlain by flat-lying reflectors, comprising partly defined topsets within $30-150 \mathrm{~m}$ of the seafloor (Cooper et al., this volume).

The drill sites were chosen with a view to stepping down through the series of prograding reflectors to record the sedimentary history since the formation of the graben. Holes were drilled at four sites on the continental shelf and one around $1000 \mathrm{~m}$ on the continental slope, between $66^{\circ} 55^{\prime} \mathrm{S}$ and $68^{\circ} 41^{\prime} \mathrm{S}$ (Table 1). The outer shelf Site 739 is $200 \mathrm{~km}$ from the coast and $30 \mathrm{~km}$ from the shelf edge, in $410 \mathrm{~m}$ of water. The innermost Site 740 is $30 \mathrm{~km}$ from the coast in $816 \mathrm{~m}$ of water in the marginal channel.

\section{SEDIMENT COMPOSITION}

\section{Grain-Size Distribution}

\section{Methods}

Bulk samples were mechanically disaggregated by smearing them out by hand with a cork and by treatment for $18 \mathrm{hr}$ with a $0.002 \mathrm{~N}$ sodium-polyphosphate solution in bottles in an endover-end shaker. The samples were washed through a $63-\mu \mathrm{m}$ sieve. The coarse fraction was dry-sieved in steps of one phi unit, and the fine fraction was subjected to a pipette analysis, also in steps of one phi unit. Duplicated determinations agree to within $\pm 1.5 \%$. Because pebbles and granules are normally under- or over-represented in small-volume samples, the gravel content of the sediments and the maximum diameter of the clasts was estimated on the cut surfaces of the cores aboard JOIDES Resolution, and following the cruise by means of core photographs. The total number of analyses was 131, distributed as follows: Site 739, 76; Site 740, 4; Site 741, 2; Site 742, 39; Site $743,10$.

\section{Results}

Most of the results are summarized in Figures 2 and 3 and Appendixes A through $\mathrm{C}$. The analysis does not include grains larger than $2 \mathrm{~mm}$. Nearly all samples are poorly sorted, with sorting coefficients according to Folk's (1966) classification between 3 and 5 phi, which confirms the visual classification (Barron, Larsen, et al., 1989). Grain-size distributions at Site 742 are mainly in the following ranges: clay, $20 \%-35 \%$; silt, 20\%-25\%; and sand, $40 \%-50 \%$. At Site 739 , farther away from the source, grain-size distributions are mainly: clay, $20 \%-25 \%$; silt, $20 \%-$ $50 \%$; and sand, $20 \%-50 \%$. Gravel contents were estimated visually and given as percentages of a complete length of a core section. The range of values is mainly $1 \%-20 \%$ by volume. (Appendixes A-F are on microfiche in back pocket.)

Grain size vs. depth plots illustrate marked variations in the proportions of clay, silt, and sand throughout Sites 742 and 739 (Figs. 2 and 3). Lithological Unit III at Site 742 and Unit III at Site 739 (described in the Stratigraphy section) tends to show the widest fluctuations, but overall the two units appear to be muddier. Otherwise, there is a slight trend upsection toward an increasing sand content, which tends to average about $50 \%-60 \%$.

The proportion of gravel, estimated visually, shows an increasing trend upsection; this matches the increasing sand content, though in a more pronounced way. The diamictites in the lower units at both Sites 742 and 739 have a low gravel content (mainly 1\%-5\%). Here they form part of a lower, gently dipping prograding unit. An upper, more steeply dipping, prograding unit (Unit IV, Site 739) shows a slightly higher gravel content (mainly 5\%-10\%). The lower parts of the overlying flat-lying sequence (Unit III, Site 742; Unit III, Site 739) have similar gravel concentrations, but with marked variations at Site $\mathbf{7 4 2}$. The highest gravel content occurs in the upper parts of the succession recovered at both sites, with concentrations usually in excess of $10 \%$, with some reaching $30 \%$.

The trends of maximum clast size are less obvious, but the larger clasts tend to occur in the flat-lying sequence at both sites. Recovered clasts are mostly less than $10 \mathrm{~cm}$ in diameter, but larger clasts tended to fracture during drilling. The largest clast recovered is a boulder measuring $60 \mathrm{~cm}$ downcore at Site 742; the largest clast at Site 739 is $20 \mathrm{~cm}$.

\section{Carbonate, Organic Carbon, and Sulfur}

\section{Methods}

Total carbon and sulfur contents were determined on freezedried samples. Grains $>2 \mathrm{~mm}$ were removed before grinding and

Table 1. Summary of drill site locations, Leg 119 (Prydz Bay).

\begin{tabular}{|c|c|c|c|c|c|c|c|c|}
\hline $\begin{array}{c}\text { Site } \\
\text { (holes) }\end{array}$ & $\begin{array}{l}\text { Latitude } \\
\text { (S) }\end{array}$ & $\begin{array}{l}\text { Longitude } \\
\text { (E) }\end{array}$ & Location & $\begin{array}{l}\text { Water depth } \\
\text { (m) }\end{array}$ & $\begin{array}{c}\text { Penetration } \\
\text { (mbsf) }\end{array}$ & $\begin{array}{l}\text { Percent } \\
\text { recovery }\end{array}$ & $\begin{array}{l}\text { Age of } \\
\text { sediment }\end{array}$ & $\begin{array}{l}\text { Principal } \\
\text { lithologies }\end{array}$ \\
\hline 739 (A-C) & $67^{\circ} 15.570^{\circ}$ & $75^{\circ} 04.914^{\circ}$ & Outer shelf & 412.3 & 487.0 & 35 & $\begin{array}{l}\text { (?late Eocene)/Oligo- } \\
\text { cene to Quaternary }\end{array}$ & Diamictite \\
\hline 740 (A-B) & $68^{\circ} 41.220^{\circ}$ & $76^{\circ} 43.246^{\circ}$ & Inner shelf & 816.0 & 225.5 & 32 & $\begin{array}{l}\text { ?Mesozoic to } \\
\text { Quaternary }\end{array}$ & $\begin{array}{l}\text { Diatom ooze, diamictite, } \\
\text { sandstone and mudstone }\end{array}$ \\
\hline $741(A)$ & $68^{\circ} 23.160^{\prime}$ & $76^{\circ} 23.020^{\circ}$ & Inner shelf & 561.4 & 128.1 & 26 & $\begin{array}{l}\text { Early Cretaceous } \\
\text { to Quaternary }\end{array}$ & $\begin{array}{l}\text { Diamicton, sandstone } \\
\text { and siltstone with coal } \\
\text { fragments }\end{array}$ \\
\hline $742(A)$ & $67^{\circ} 32.982^{\prime}$ & $75^{\circ} 24.270^{\circ}$ & Mid-shelf & 410.0 & 316.0 & 53 & $\begin{array}{l}\text { (?late Eocene)/Oligo- } \\
\text { cene to Quaternary }\end{array}$ & Diamictite \\
\hline $743(A)$ & $66^{\circ} 54.994^{\circ}$ & $74^{\circ} 41.423^{\circ}$ & $\begin{array}{l}\text { Continental } \\
\text { slope }\end{array}$ & 987.0 & 98.1 & 22 & Pliocene to Quaternary & Mud, diamicton \\
\hline
\end{tabular}




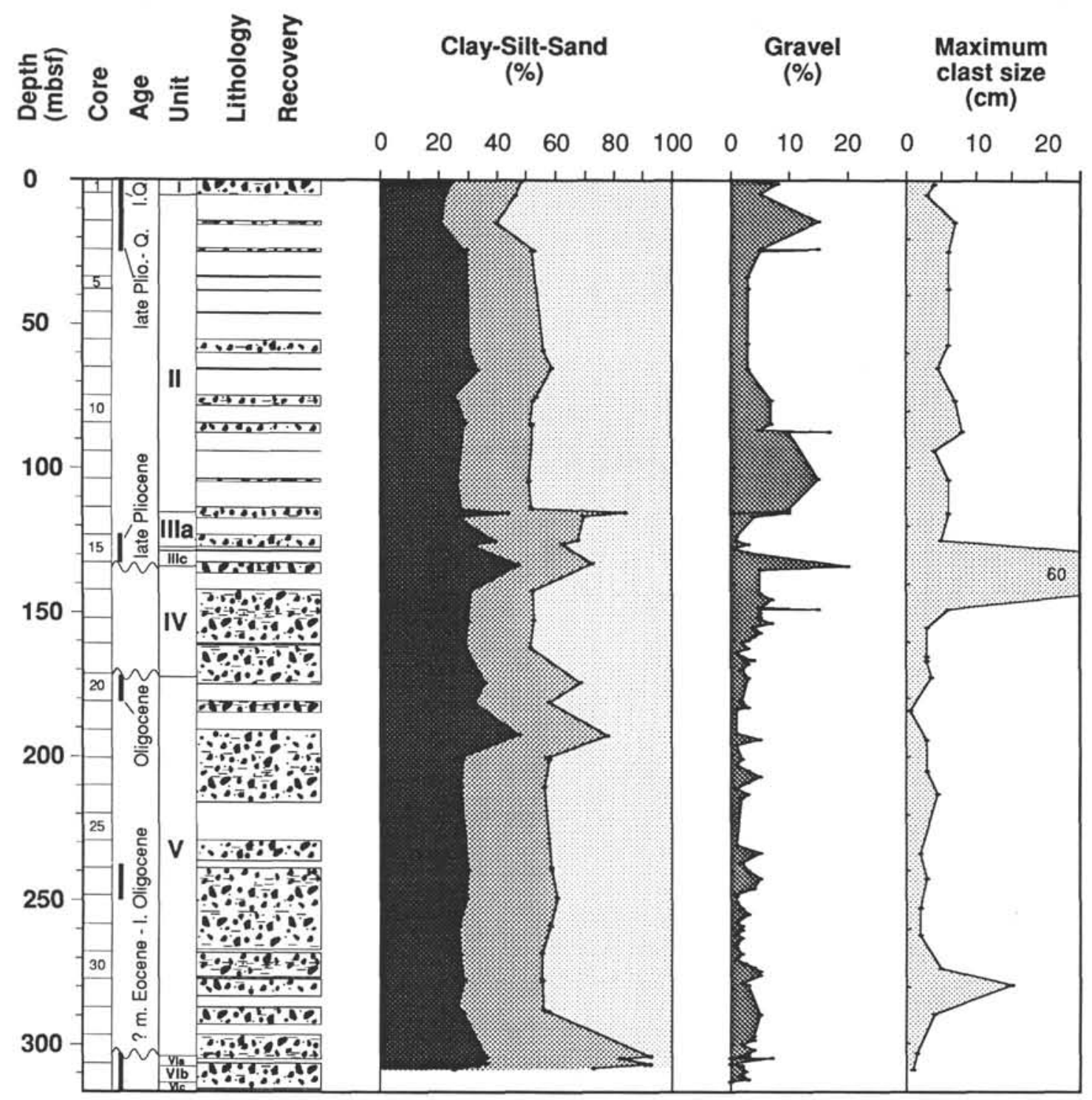

Figure 2. Plots of grain-size variations with depth, including visually estimated gravel content (determined separately from the bulk core) and largest clast size (length of longest axis on cut face of core), Site 742.

measuring with a CS-125 Carbon-Sulfur Determinator (LECO Corporation). Organic carbon $\left(\mathrm{C}_{\text {org }}\right)$ was measured on a corresponding sample treated with $\mathrm{HCl}$ to remove carbonate. Carbonate was calculated as weight percent. Our data fit very well to those collected aboard JOIDES Resolution (Barron, Larsen, et al., 1989).

\section{Results}

The carbonate content of Sites 739 and 742 are generally low throughout and show only minor fluctuations (Figs. 4 and 5, and Appendix D). The carbonate concentrations of Site 742 normally are $<1 \%$. Only in Unit IV are the values higher, typically around $1.5 \%$. At Site 739 , Units V, II, and I show the same level of carbonate contents, about $1 \%$. In Units IV and III, the carbonate concentrations are higher and range from $1 \%$ to $3 \%$. Sporadic carbonate-cemented layers occur in the lower parts of both Sites 742 (Unit V) and 739 (Unit V). These were not sampled, however.
The concentrations of organic carbon at Site 742 are relatively constant at about $0.5 \%$ in Units VI and V. A distinct increase to $1 \%-1.5 \%$ can be noted in Unit IV. Lower, but again relatively constant, concentrations of $0.3 \%$ characterize Units III, II, and I (Fig. 4 and Appendix D2). At Site 739 the organic carbon content shows slightly stronger fluctuations (Fig. 5 and Appendix D1). It averages about $0.4 \%$ from 490 to $440 \mathrm{mbsf}$ and $0.6 \%$ from 440 to 230 mbsf. In the upper part of Subunit IIIC and in Subunit IIIB (230-195 mbsf) mean concentrations are $0.3 \%$. A distinct maximum with $1 \%-2 \%$ organic carbon occurs between 190 and 100 mbsf in the lower part of Unit II. The upper part of the sedimentary sequence again has a low organic carbon content of about $0.3 \%$.

The sulfur content of sediments at both Sites 742 and 739 generally is very low (Appendix D). At Site 742 concentrations are mainly $<0.1 \%$, at Site $739<0.3 \%$. Maximum concentrations occur in Units VI and V of Site 742 and in Units IV and III of Site 739. In most parts at Sites 742 and 739 the sulfur con- 

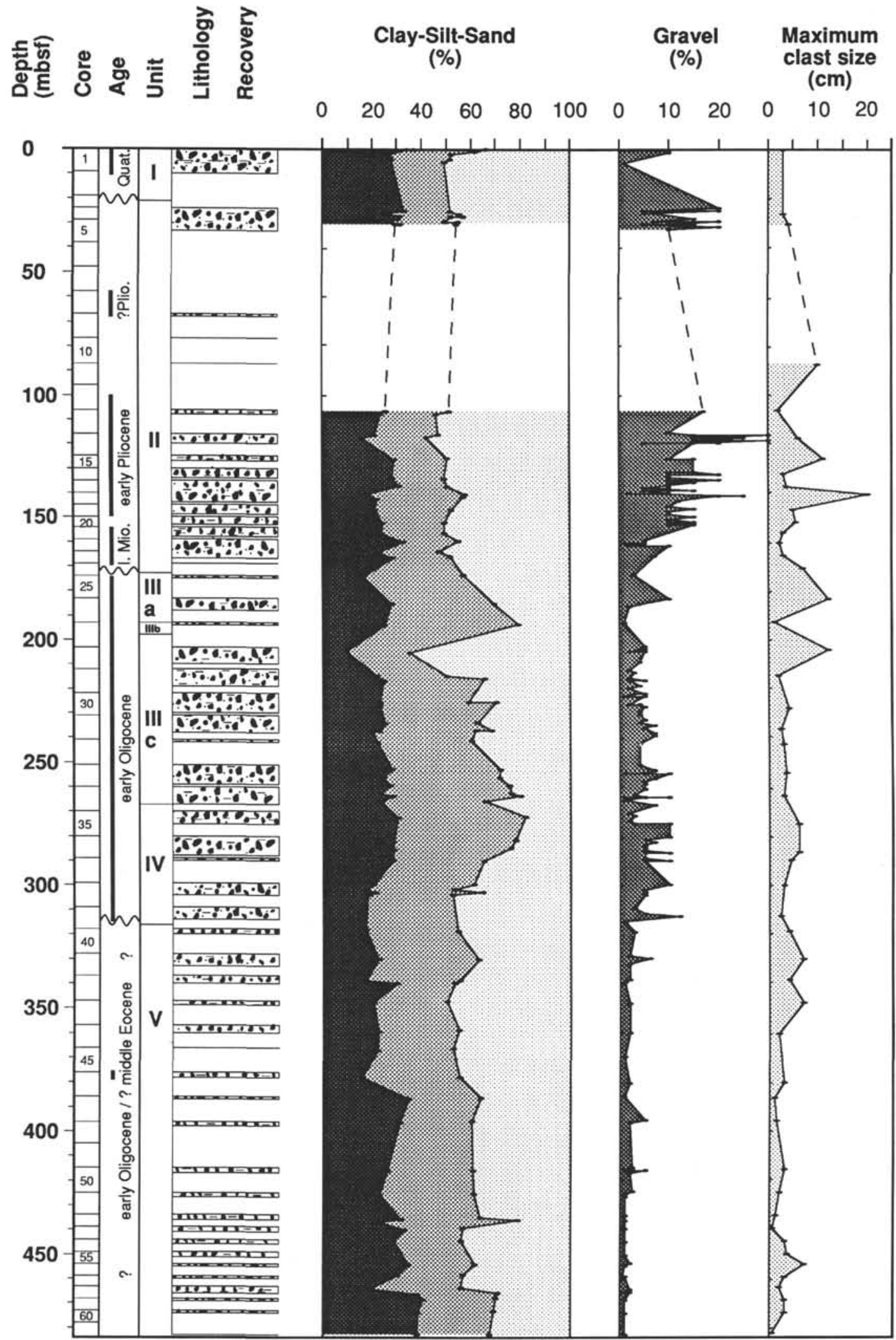

Figure 3. Plots of grain-size variations with depth, including visually estimated gravel content (determined separately on the bulk core) and largest clast size (length of longest axis on cut face of core), Site 739. 


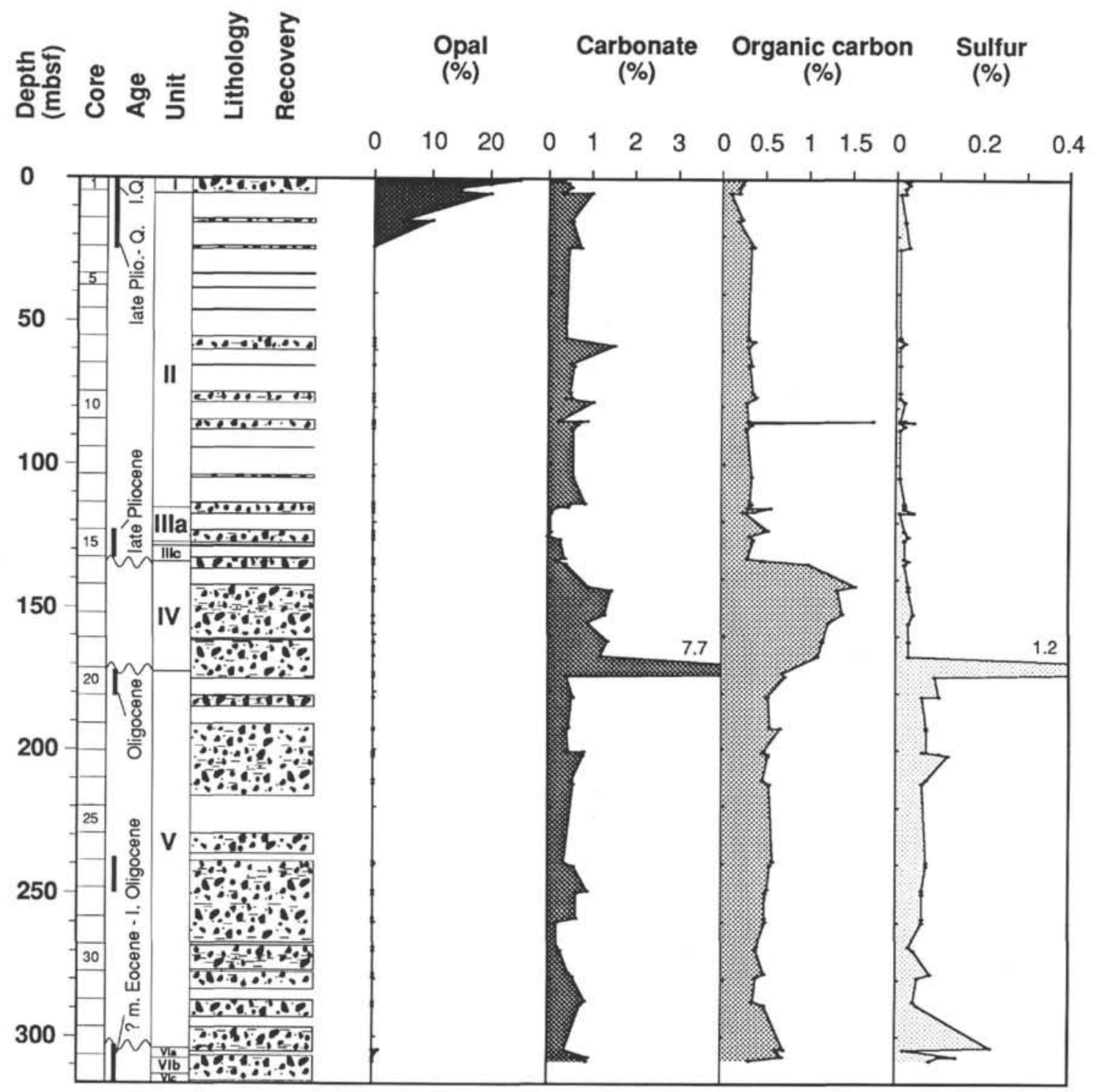

Figure 4. Variation of opal (representing diatom abundance), carbonate, organic carbon, and sulfur according to depth; Site 742.

centrations correlate with the content of $\mathrm{C}_{\text {org }}$. However, the $\mathrm{C}_{\text {org }}$ maxima of Unit IV of Site 742 and of the lower part of Unit II at Site 739 do not have counterparts in the sulfur concentration.

\section{Opal}

\section{Methods}

The opal content of all samples analyzed was estimated from recognizable diatoms in smear slides. Diatoms are the most dominant biogenic component of Prydz Bay cores.

\section{Results}

At Site 742 opal was detected in samples from the uppermost three cores only (Fig. 4 and Appendix D). Concentrations reach $25 \%$. In the deeper parts of the site, opal is totally missing or only occurs in minor trace amounts. At Site 739 opal plays a more important role than at Site 742 . Opal is present down to a depth of about $315 \mathrm{mbsf}$, which corresponds to the base of lithologic Unit IV (Fig. 5 and Appendix D). Concentrations are highest in Units IV, III, and I, and range from $10 \%$ to $25 \%$.
Unit II, in contrast, shows more variable but generally lower opal contents.

\section{Clay Mineralogy}

\section{Methods}

Clay mineral determinations were made on 75 samples from Site 739,39 from 742,6 from 743 , and a few from surficial sediments at Sites 740 and 741 . Sites 739 and 742 provide a comprehensive record of changes in chlorite, illite, kaolinite, and smectite through the glacial sequence. The clay mineral composition was analyzed by X-ray diffraction of the $<2-\mu \mathrm{m}$ fraction, which was separated by the Atterberg method (settling time based on Stoke's Law). The samples were mounted as texturally oriented aggregates and solvated with ethylene-glycol vapor at a temperature of $60^{\circ} \mathrm{C}$. The measurements were conducted on a Phillips PW 1700 automated powder diffraction system with $\operatorname{CoK} \alpha$ radiation $(40 \mathrm{kV}, 40 \mathrm{~mA})$, a graphite monochromator, an automatic divergence slit, and an automatic sample changer. The samples were $X$-rayed in the range $2^{\circ}-40^{\circ} 2 \theta$ with a speed of 


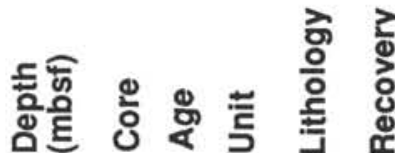

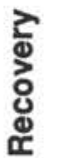
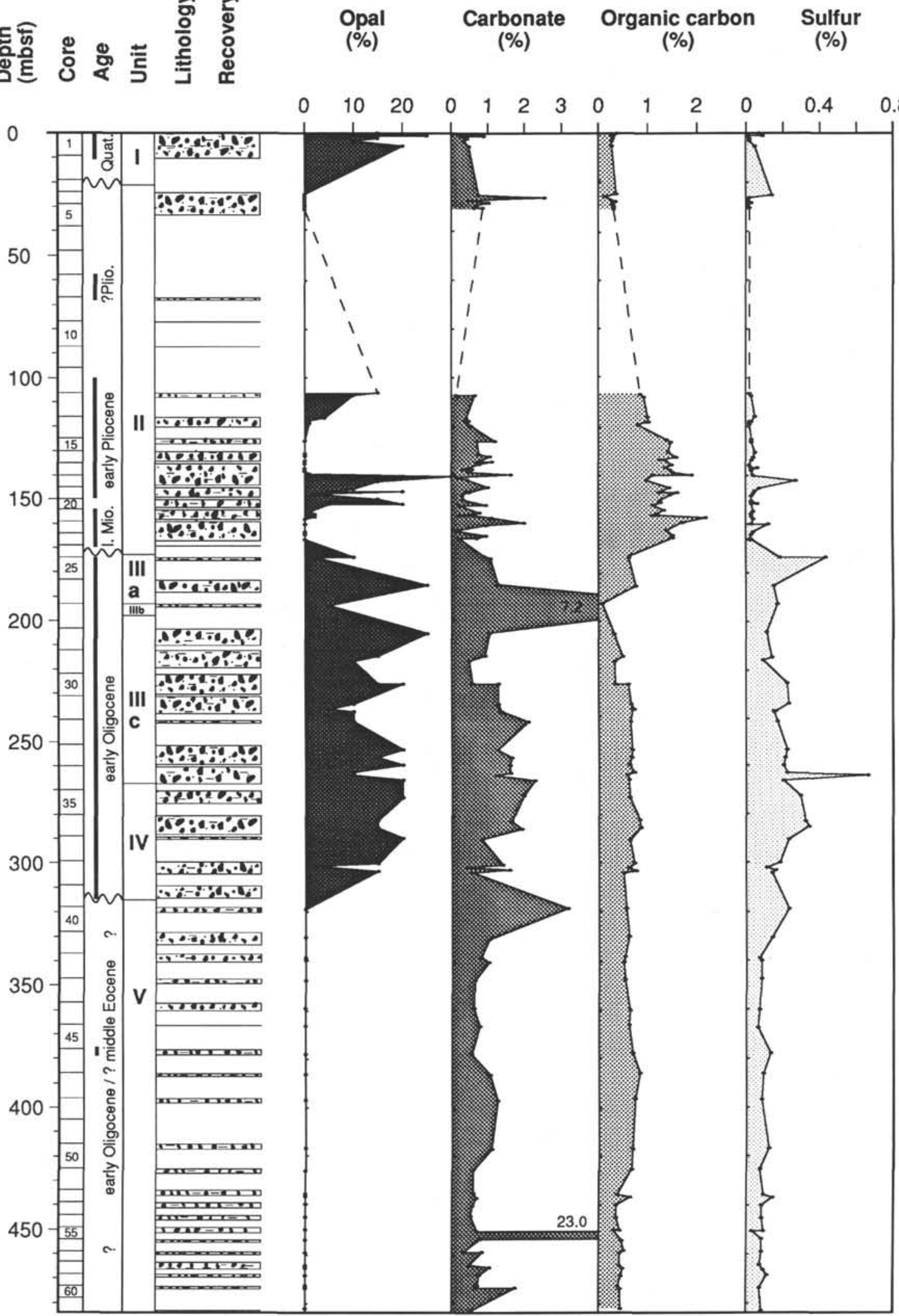

Figure 5. Variation of opal (representing diatom abundance), carbonate, organic carbon, and sulfur according to depth; Site 739 . 
$0.02^{\circ} 2 \theta$ per second. For semiquantitative evaluations of the clay mineral assemblage we used empirically estimated correction factors on integrated peak areas of the individual clay mineral reflections from the glycolated samples (Biscaye, 1964, 1965; Brindley and Brown, 1980; Lange, 1982). These weighting factors are valid for a fixed slit. Using an automatic slit results in a slight shift of the real concentrations. Therefore, in this paper mainly relative changes in the concentration patterns of smectite, illite, chlorite, and kaolinite are considered.

\section{Results}

The clay minerals smectite, illite, chlorite, and kaolinite show distinct concentration patterns through time in both Site 742 and Site 739 (Figs. 6 and 7 and Appendix E). In the deepest part of these sites, kaolinite concentrations average around $60 \%$, but concentrations decrease continuously upcore until they reach a point above which kaolinite concentrations remain constant at $\approx 20 \%$. The nick point in the concentration curve at Site 742 is located at $\approx 140 \mathrm{mbsf}$, in the upper part of lithologic Unit IV. At Site 739 it occurs at $\approx 280$ mbsf, in the upper part of lithologic Unit IV.
The illite and chlorite concentrations in the clay fraction show an opposite trend to that of kaolinite. They increase upcore as kaolinite decreases. In the lower part of the two sites, chlorite concentrations range from $5 \%$ to $15 \%$, but in the upper part they reach $30 \%$. Illite concentrations fluctuate around $20 \%$ and $60 \%$ in the deeper and upper parts of both sites, respectively.

Smectite shows concentrations fluctuating between $2 \%$ and $20 \%$. The highest values are found in the Oligocene part of Sites 739 and 742 . Vermiculite was identified on the basis of the $14.5-\AA$ reflection from the glycollated samples in sediments beneath the Oligocene/Miocene hiatus at about $173 \mathrm{mbsf}$ in Site 739. This mineral is most common between 173 and about 250 mbsf.

\section{LITHOFACIES DESCRIPTION}

The Prydz Bay cores in this paper are described in terms of the following principal lithofacies: diamicton, sand, mud, and diatomaceous ooze and their lithified equivalents. Subfacies are designated according to the character of stratification and grainsize distribution. Percentages of each main lithofacies from

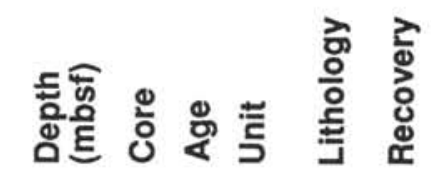

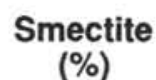

$0 \quad 10 \quad 20$
Illite

(\%)
Chlorite

(\%)
Kaolinite

(\%)

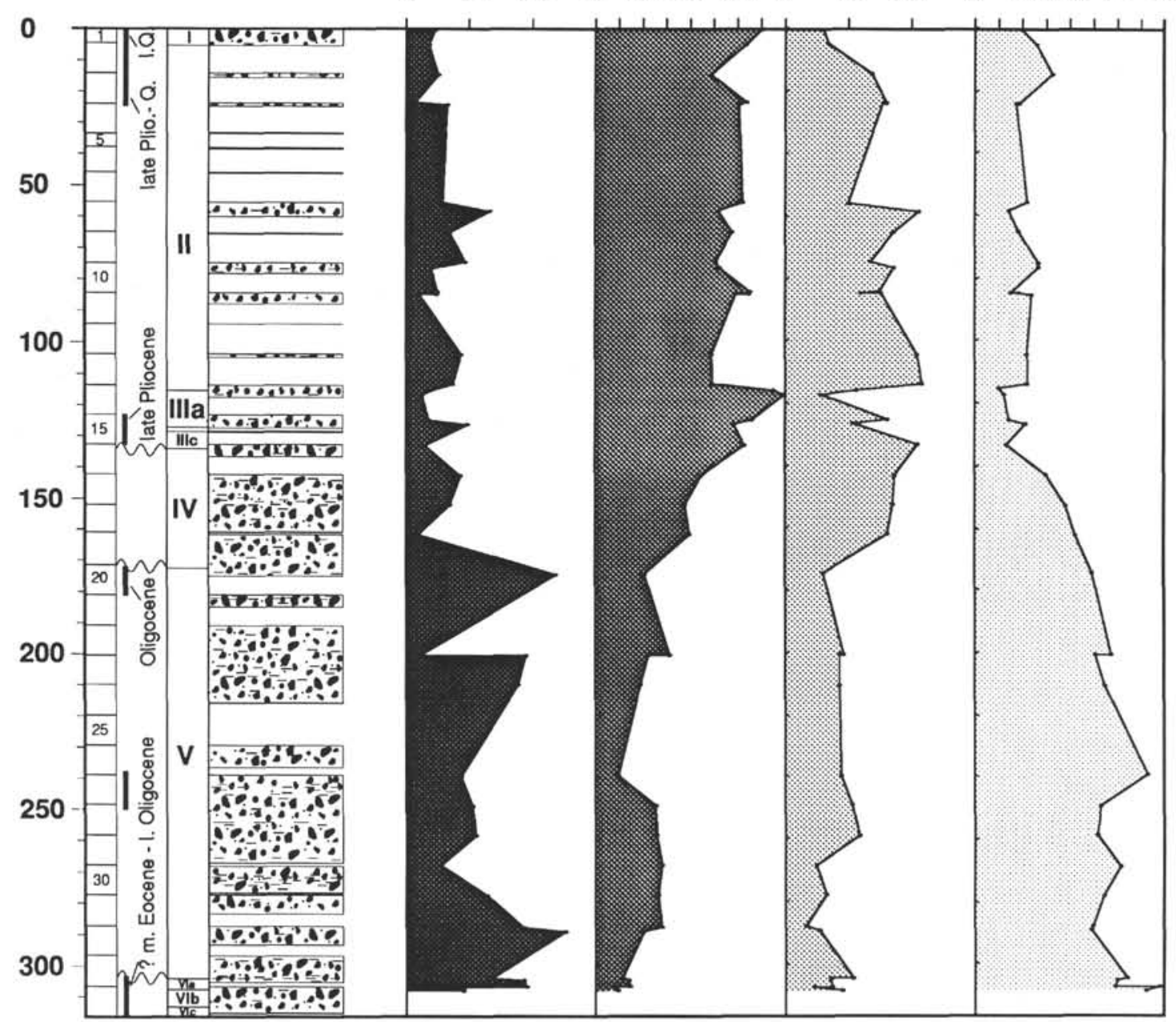

Figure 6. Variation of principal clay minerals according to depth; Site $\mathbf{7 4 2 .}$ 

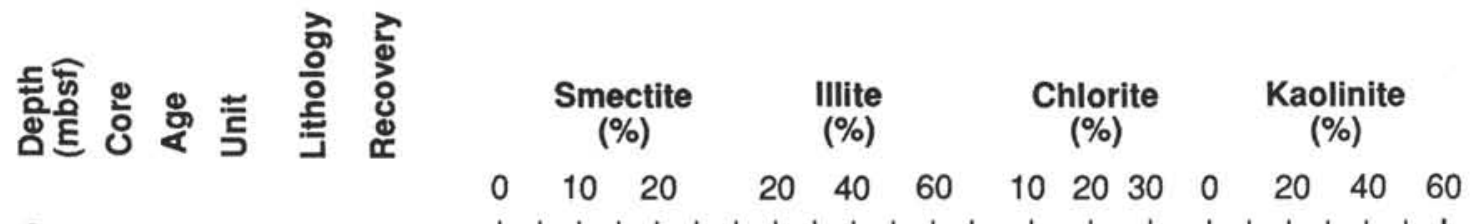

0

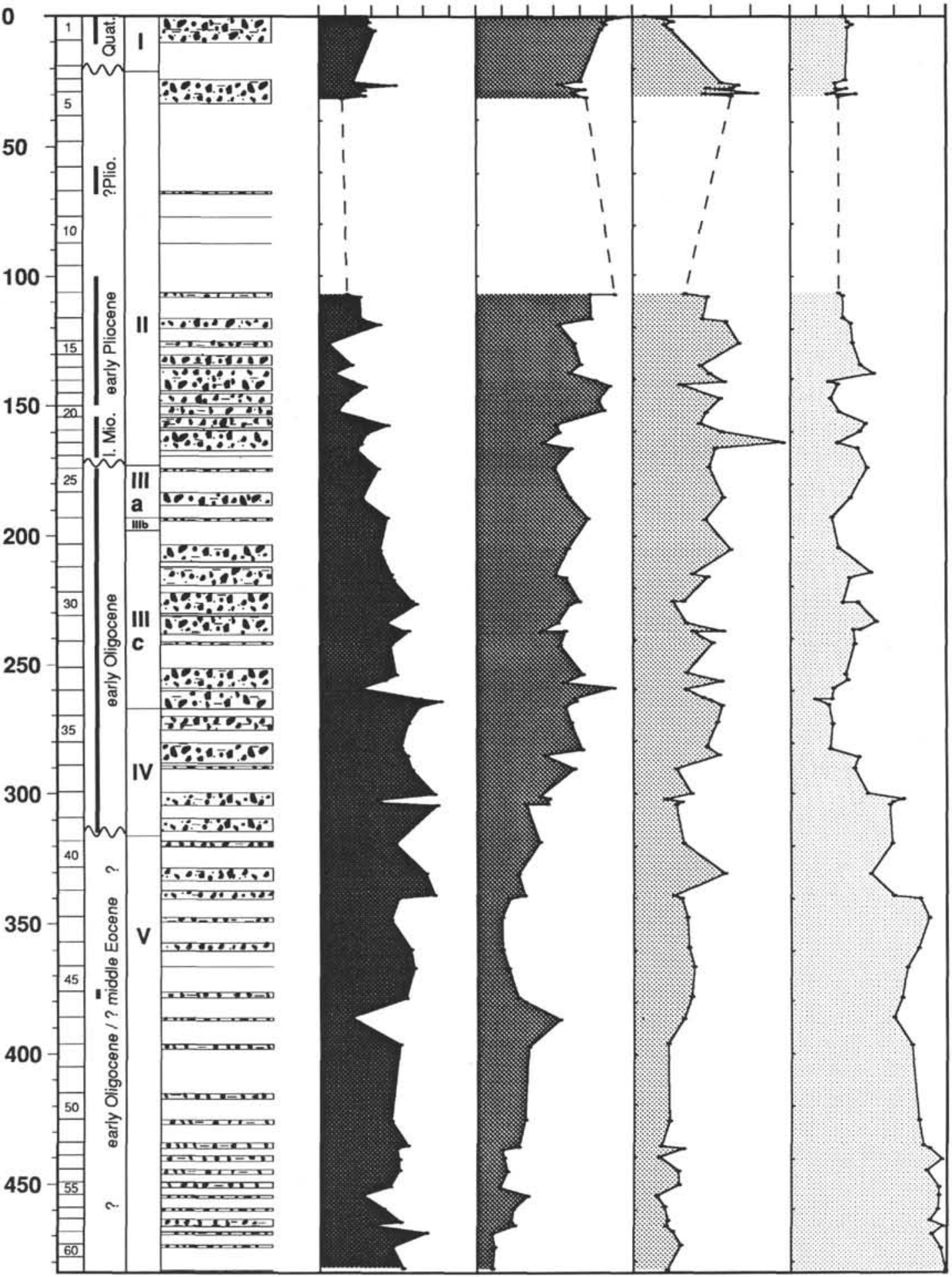

Figure 7. Variation of principal clay minerals according to depth; Site 739. 
Sites 739 and 742 , sites which provide the most complete sedimentary record, are given in Table 2. Abbreviations for lithofacies are used on the sedimentary logs and summarized in Table 3.

The term diamictite was originally defined as "essentially non-sorted, non-calcareous, terrigenous deposits composed of sand and/or gravel particles in a muddy matrix" (Flint et al., $1960 \mathrm{a}, 1960 \mathrm{~b})$. The noncalcareous restriction has been dropped in modern usage, as many clasts and part of the matrix might be of carbonate. Diamicton is the unlithified equivalent of diamictite, and diamict embraces both (Harland et al., 1966). Diamict is now frequently used as a nongenetic term for describing poorly sorted sediments, typified by glaciogenic and debris-flow deposits, especially where their precise mode of emplacement is uncertain.

A quantitative textural classification, based on the relative proportions of mud, sand and gravel, for diamicts and other poorly sorted sediments was developed by Moncrieff (1989). This classification is summarized in Table 4. In fully defining diamict facies sedimentologically we combine the textural classification with a description of the type of stratification, that is whether the rock is massive, weakly stratified or well stratified (e.g., weakly stratified, clast-rich sandy diamictite). If estimates of grain-size proportions have not been determined, or where broad facies categories are being discussed, we refer only to bedding characteristics in designating subfacies.

Other facies are described according to ODP procedures (Barron, Larsen, et al., 1989; p. 22) as far as possible. Most facies grade into one another, so clear distinctions between them cannot always be made. The principal facies are described as follows.

\section{Diamict Facies}

\section{Massive Diamictite/Diamicton (Dm)}

This facies is a sandy mud(stone) or muddy sand(stone), the sand and mud being of approximately equal proportions, together with matrix-supported clasts comprising $1 \%-20 \%$ of the sediment (Pl. 1, Figs. 1 and 2). Clasts are of all shapes, but are predominantly subangular and subrounded. Unconsolidated diamicton occurs in approximately the upper $10 \mathrm{~m}$ of Sites 739-742 on the shelf, but at Site 743 it is developed throughout. The bulk of the recovered material is overconsolidated or consolidated in the geotechnical sense. Bedding is absent. Some horizons show high-angle slickenside surfaces. As far as the recovery allows, it appears that individual beds may be continuous vertically for tens of meters. The sediment is massive and homogeneous, with gradual changes in clast volume. Scattered intact or broken fossil shells, a few millimeters across, are present. A few well-defined massive beds show crude grading and sharp upper and lower contacts. Massive diamict accounts for $70 \%$ and $90 \%$ of recovered core at Sites 739 and 742 , respectively, and is also dominant in the upper parts of Sites 740 and 741 and throughout Site 743.

\section{Weakly Stratified Diamictite (Dw)}

Compositionally weakly stratified diamictite is similar to massive diamict, but generally with less gravel $(1 \%-10 \%)$. No unlithified varieties were recovered. Stratification is diffuse or wispy on a centimeter scale, and is defined by slight variations in the sand and mud content (Pl. 1, Fig. 3). Commonly the

Table 2. Cumulative thickness and percentage of recovered facies in Prydz Bay Sites 739 and 742. These data refer to recognizable facies only; the remainder include loss due to break up of core, whole-round samples removed before core description, and slurried parts of the core.

\begin{tabular}{|c|c|c|c|c|c|}
\hline \multirow{2}{*}{ Facies } & \multirow{2}{*}{$\begin{array}{l}\text { Abbrev- } \\
\text { iation }\end{array}$} & \multicolumn{2}{|c|}{ Site 739} & \multicolumn{2}{|c|}{ Site 742} \\
\hline & & $\begin{array}{c}\text { Recovery } \\
\text { (m) }\end{array}$ & $\begin{array}{c}\text { Facles recovery } \\
(\%)\end{array}$ & $\begin{array}{l}\text { Recovery } \\
\text { (m) }\end{array}$ & $\begin{array}{c}\text { Facles recovery } \\
(\%)\end{array}$ \\
\hline $\begin{array}{l}\text { Diamictite } \\
\text { (massive) }\end{array}$ & $\mathrm{Dm}$ & 106.1 & 70.9 & 146.3 & 90.5 \\
\hline $\begin{array}{l}\text { Diamictite (weakly } \\
\text { stratified) }\end{array}$ & Dw & 24.5 & 16.4 & 5.2 & 3.2 \\
\hline $\begin{array}{l}\text { Diamictite (well } \\
\text { stratified) }\end{array}$ & Ds & 11.1 & 7.4 & 0.9 & 0.6 \\
\hline $\begin{array}{l}\text { Diatomaceous } \\
\text { ooze/diatomite }\end{array}$ & DO & $\cdots$ & $\cdots$ & 0.4 & 0.2 \\
\hline $\begin{array}{l}\text { Diatomacous } \\
\text { mudstone }\end{array}$ & $\mathrm{DM}$ & 7.4 & 4.9 & 0.3 & 0.2 \\
\hline $\begin{array}{l}\text { Mudstone } \\
\text { (massive) }\end{array}$ & $\mathrm{Mm}$ & 0.1 & 0.1 & 1.0 & 0.6 \\
\hline $\begin{array}{l}\text { Mudstone } \\
\text { (stratified) }\end{array}$ & Ms & 0.5 & 0.3 & 7.0 & 4.2 \\
\hline $\begin{array}{l}\text { Sandstone } \\
\text { (poorly sorted) }\end{array}$ & MS & $\ldots$ & $\cdots$ & 0.3 & 0.2 \\
\hline $\begin{array}{l}\text { Sandstone } \\
\text { (well sorted) }\end{array}$ & $\mathrm{s}$ & $\ldots$. & $\ldots$. & 0.3 & 0.2 \\
\hline Totals & & 149.7 & & 161.7 & \\
\hline $\begin{array}{l}\text { Rock fragments/ } \\
\text { loose clasts }\end{array}$ & & 1.2 & & 1.6 & \\
\hline
\end{tabular}


Table 3. Summary of facies abbreviations used in this paper. Diamictite

D Diamictite, clast-rich

D Diamictite, clast-poor

$\begin{array}{cl}\text { Prefixes for diamictite } \\ \text { M } & \text { Muddy } \\ \text { I } & \text { Intermediate } \\ \text { S } & \text { Sandy }\end{array}$

\section{Other facies}

S Sandstone

MS Muddy sandstone

M Mudstone

SM Sandy mudstone

DM Diatomaceous mudstone

DO Diatom ooze, diatomite

\section{Suffixes applicable to all facies}

$\begin{array}{ll}\text { m } & \text { Massive } \\ \text { w } & \text { Weakly stratified } \\ \text { s } & \text { Well stratified }\end{array}$

stratification is contorted. Sedimentary structures are well developed and include slump folds, dismembered slump folds, synsedimentary faults, burrows, mottling (due to bioturbation) (Pl. 1. Fig. 4), load structures, dropstones, rare mud intraclasts, and (at some levels) slickensides that are commonly oriented parallel to inclined beds. In addition to clastic material, some weakly stratified diamictite contains a small percentage $(<10 \%)$ of diatoms. Small shelly fossils, both broken and intact, occur in places (Pl. 1, Fig. 4). Weakly stratified diamictite is the next most abundant facies, but was observed only at Sites 739 and 742 , where they represent $16 \%$ and $3 \%$ of the recovered core, respectively. No unlithified equivalent was recorded, although the disturbance suffered by the higher cores during rotary drilling may have turned it into massive diamicton.

\section{Well-Stratified Diamictite (Ds)}

Well-stratified diamictite is also compositionally similar to massive diamictite, except that up to $30 \%$ diatoms can be present. Also, the proportion of gravel clasts is lower. All well-stratified facies recovered were lithified. Stratification is well defined on a centimeter scale and is continuous as far as the dimensions of the core (PI. 1, Fig. 6). However, the precise boundaries between the thin beds are diffuse. Some bedding is defined by variations of diatom content, but mainly by changing proportions of mud and sand. The beds are commonly contorted. There is the same range of sedimentary structures as in weakly stratified diamictite, but they are better developed. This facies was observed only at Sites 739 and 742 , where it makes up $7 \%$ and $0.1 \%$ of the recovered core, respectively.

Each of the preceding diamictite facies has been further subdivided: grain-size analyses into sandy, intermediate, and muddy varieties and estimates of gravel clast proportions have allowed designation of clast-rich and clast-poor varieties (Table 4).

\section{Other Facies}

\section{Diatomaceous Mud(stone) (DM)}

Diatomaceous mud(stone) is generally a clayey siltstone or silty claystone with more than $20 \%$ diatoms and minor sand. It occurs as internally massive beds and is closely associated with stratified diamictite. At Site 739 it represents $5 \%$ of the recovered material, but only $0.3 \%$ at Site 742 . It occurs also as a soft, diatomaceous sandy mud in the uppermost parts of Sites 740, 741 , and 742 . The diatomaceous mud facies is generally transitional with diatom ooze referred to below.

\section{Stratified Mudstone (Ms, minor Mw)}

This facies varies from stratified sandy mudstone (SMs) to stratified gravelly sandy mudstone (GMs), the latter containing up to $7 \%$ fine gravel (Pl. 2, Fig. 3). One good dropstone structure was observed (Pl. 2, Fig. 1). It is mostly well stratified on a millimeter to centimeter scale, and the beds are flat lying, although contacts are slightly disturbed. The weakly stratified mudstone is compositionally similar. The bulk of this facies occurs toward the base of Site 742. A minor part of the stratified mudstone has a rhythmically laminated (millimeter scale) appearance (facies $\mathrm{R}$ ), with each rhythm showing normal grading. A few small shelly fossils were found, but there is no sign of any other biogenic material. This facies accounts for $3 \%$ of the sediment recovered from Site 742 , but only $0.3 \%$ from Site 739 .

\section{Massive Sandy Mudstone (SMm)}

Massive sandy mudstone is a minor component $(0.1 \%)$ of Site 739 . It is a sandy silty claystone with dispersed gravel $(<1 \%)$ and a few diatoms and small broken shelly fossils. Apart from the low gravel content, this facies is similar to diamictite (Pl. 2, Fig. 4).

\section{Muddy Sandstone (MS)}

Muddy sandstone is a clayey silty sandstone that forms a minor part of Site $742(0.2 \%)$. It shows coarse-tail grading and signs of soft-sediment deformation. A few intraclasts of mudstone are present.

\section{Diatom Ooze and Diatomite (DO)}

Diatom ooze and diatomite are minor facies, comprising less than $1 \%$ of the cores, that contain more than $60 \%$ diatoms. Other components include clay, silt, sand, and a trace of gravel (Pl. 2, Fig. 2). The ooze is soft and was much disturbed during core recovery. It forms the uppermost parts of all sites except Site 739. The diatomite is firm but not indurated. It has a loaded base and contains mudstone intraclasts. Stratification is weak or absent.

\section{Sandstone (S)}

The sandstone facies consists of well-sorted whitish loose sand and sandy silt. It occurs only near the base of Site $\mathbf{7 4 2}$ $(0.2 \%$ of the recovered core), where it was involved in intense soft-sediment deformation (folding) with diamictite and mudstone. Any original stratification has been destroyed. The sand is immature and contains mica flakes and lignite clasts.

\section{Grain-Size Distribution According to Facies}

Grain-size analyses of the sand and finer fraction are plotted on triangular diagrams (Figs. 8-10) and histograms (Fig. 11) according to the previously described principal facies. Diamicts are further grouped on the triangular diagrams according to whether the samples were obtained from the Miocene to Quaternary flat-lying sequence (represented in both Sites 742 and 739), 
Table 4. Quantitative textural classification for lithified, poorly sorted sediments containing gravel. For unconsolidated sediments, diamicton is the appropriate term (after Moncrieff, 1989).

Increasing gravel content

Gravel (>2 $\mathrm{mm}$ ) in whole rock, estimated from core $(\%)$

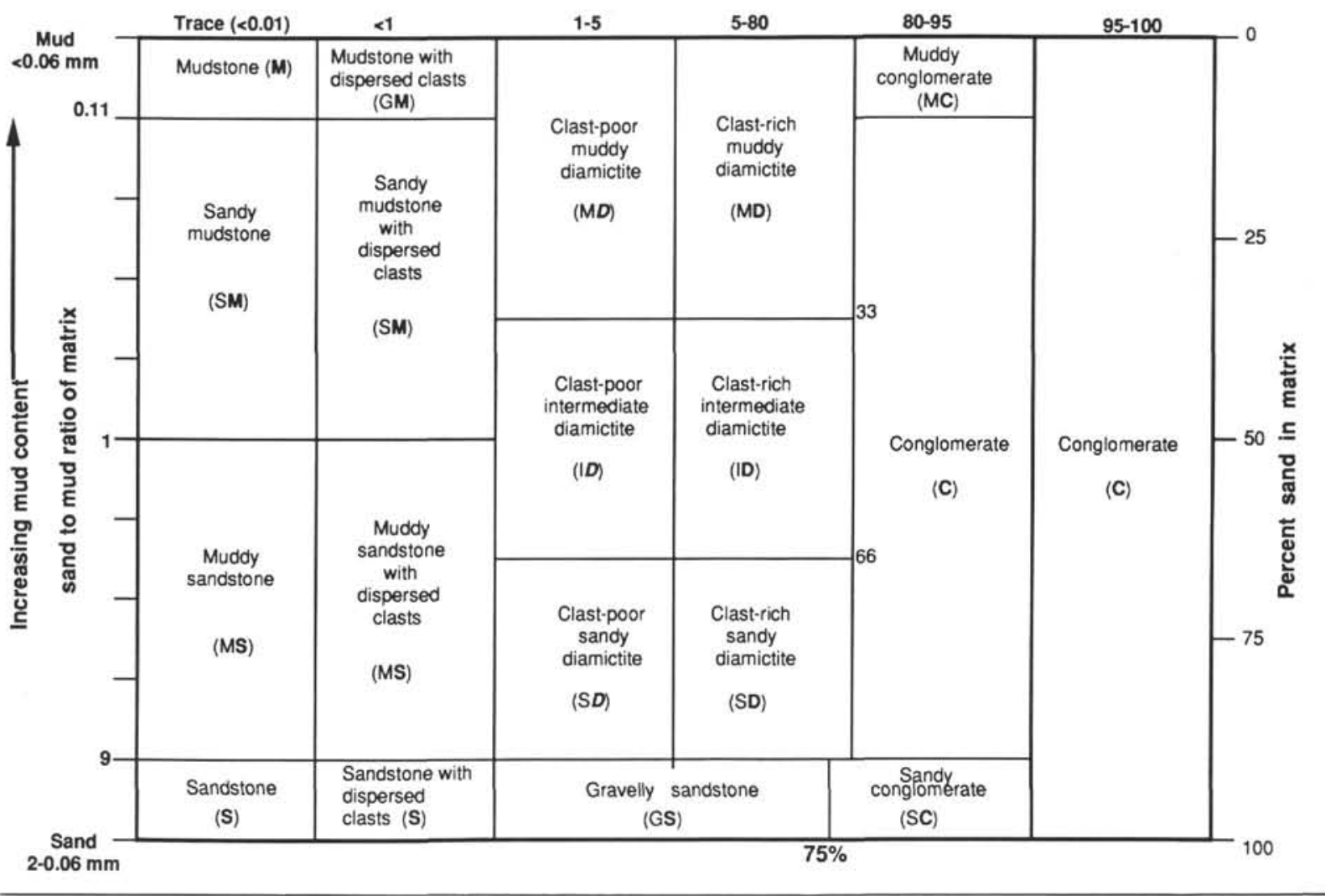

the upper younger Oligocene prograding sequence (Site 739), the lower older Oligocene (possibly Eocene) less steeply inclined prograding sequence (Sites 742 and 739 ), and the sequence on the continental slope (Site 743) (Figs. 8-10). The more steeply inclined prograding sequence at Site 739 is analogous to the sediments that form the present-day continental slope at Site 743 .

Massive diamicts have a broad spread of grain sizes with weak peaks in the sand and clay ranges (Fig. 11) or, rarely, in the clay range only. This facies falls within a broad but well-defined field in the center of the triangular plot. The small data set from Site 742 shows no systematic difference between each of the main sequences (Fig. 8A). However, Site 739 indicates a sandierclayier composition in the flat-lying sequence than in the upper prograding sequence, while the data points for the lower prograding sequence tend to fall in between (Fig. 9A).

Weakly and well-stratified diamictites also have a broad spread of grain sizes (Fig. 11), but with more variability, although there is a tendency toward stronger modes in the clay range. On the triangular diagrams data points for weakly and well-stratified diamictites at Site 739 show no clear difference from the massive facies, but in Site 742 the stratified facies are clearly more muddy. The samples from the upper prograding sequence of Site 739 contain clearly less sand than the outermost part of the prograding unit at Site 743 .

Statistical determinations on the grain-size data (Appendix C) include mean grain size and sorting and indicate that all diamict samples belong to the "very poorly sorted" field, with sorting coefficients ranging mainly from 3 to 4.5 phi. Comparison between the diamict facies indicates that there are no significant differences. Stratified and nonstratified diamicts are simi- lar, and the sandy mudstones and diatomaceous mudstone also have the same sorting characteristics.

Almost all other gravel-poor facies, which are represented by a variety of typically diatomaceous mudstones and sandy muds, are also very poorly sorted. Diatomaceous mudstone (DM in Fig. 11) shows a slightly pronounced silt mode and sandy mud(stone)s (SMs) show weak sand and clay modes or clay mode only. The absence of gravel is the only significant difference, suggesting a common source. Exceptions are a well-sorted sand (S) from Site 743 (Figs. 10 and 11) and the medium-sorted pelagic diatom ooze from Site 740 and possibly Site 741 (not shown), which chiefly reflect the size distribution of diatoms in a natural population.

In terms of the diamictite textural classification of Moncrieff (1989), most diamictites are of the intermediate variety, regardless of whether they are massive or stratified (Figs. 12 and 13). Some muddy diamictites occur, but are mainly confined to the units with mixed facies, especially Unit III at Site 739 and Units III and VI at Site 742. Clast-poor varieties of diamictite (1\%$5 \%$ gravel) dominate the prograding sequences, whereas clastrich varieties ( $>5 \%$ gravel) form much of the flat-lying sequence.

\section{Shape of Gravel Clasts}

Shape estimates were made of clasts in the diamictites at Sites 742 and 739 to assist in the characterization of transport processes (Figs. 14 and 15 and Appendix F).

Almost all samples have shapes in all four main classes, from rounded to angular, with peaks tending to occur in the subangular and subrounded classes, which together account for $70 \%$ - 

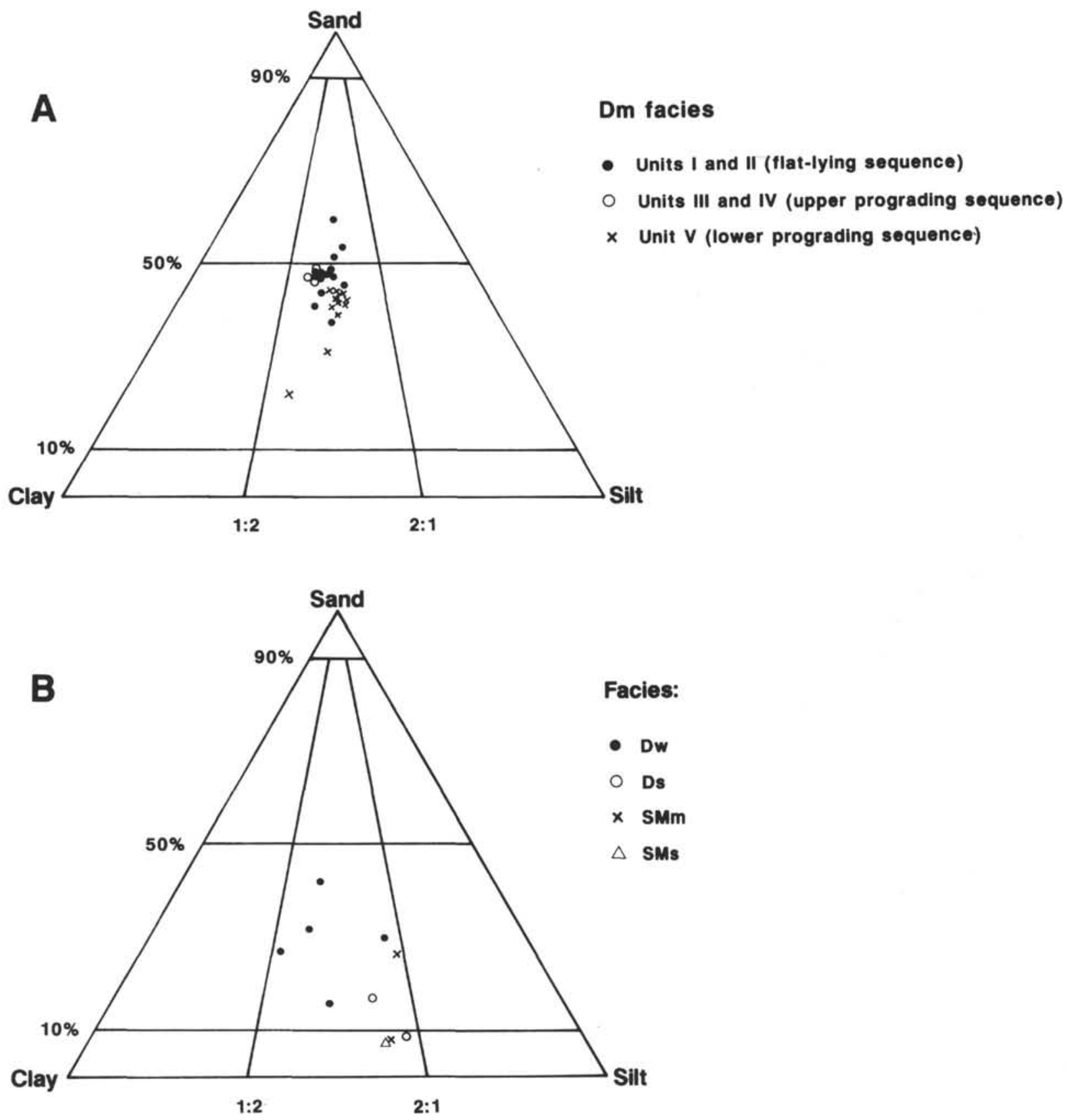

Figure 8. Triangular plots of the sand-sized and finer fraction according to facies and lithological units, Site 742. A. Massive diamictite (Dm) facies. B. Other facies. (see Table 3 for facies abbreviations.)

$80 \%$ of all clasts. There appear to be no systematic changes downcore at either site.

Some foliated and sedimentary clasts have well-defined facets, and a few have bullet-nosed shapes. Striated clasts are extremely rare, because most lithologies are coarse grained and have not been susceptible to acquiring striae. Striations were only noted on fine-grained amphibolite and coal clasts.

\section{Grain Fabrics in Diamicts}

To provide additional constraints on the mode of deposition of diamictites, a number of two-dimensional grain fabric determinations were made at Sites 739 and 742 . In particular, we wished to determine whether deposition of massive diamict was more likely from grounded ice or floating ice. In the absence of data concerning bedding relationships because of poor recovery, we could not make any confident assessment of the depositional environment from visual characteristics alone. Although threedimensional measurements would have been preferable, this would have entailed demolishing large parts of the core.

Grain fabrics were determined on horizontal half slices of core as the opportunity arose aboard ship. The orientations of all elongate grains were recorded under a binocular microscope with reference to a common baseline following the method used during CIROS-1 drilling in McMurdo Sound (Hambrey, 1989). The grains varied in length from about $1 \mathrm{~mm}$ to small pebble size and had long to short axis ratios of $1.5: 1$ or greater. The most suitable grains tended to be crystals of feldspar and flecks of black organic material. In most cases, 50 readings were made 

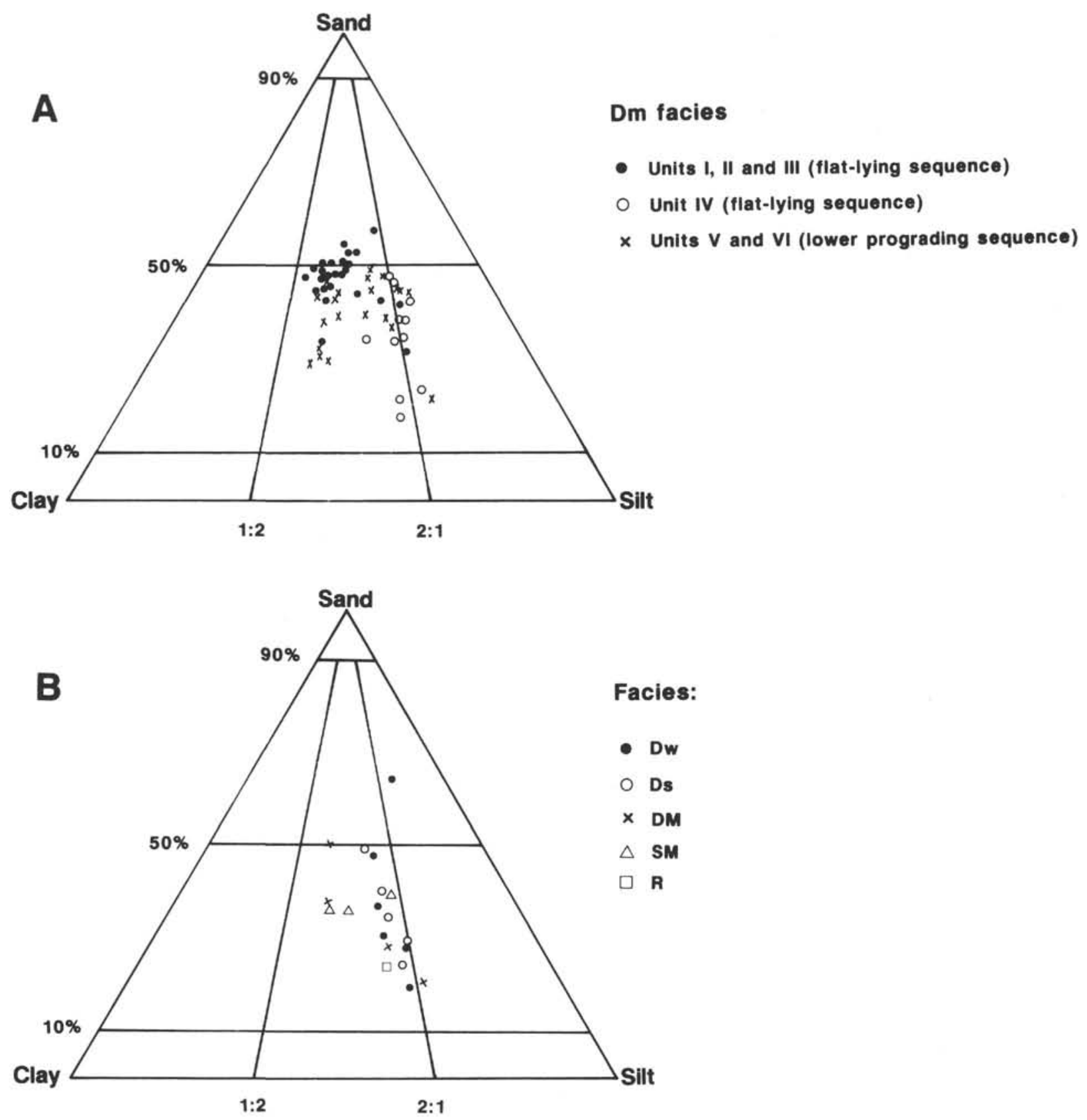

Figure 9. Triangular plots of the sand-sized and finer fraction according to facies and lithological units, Site 739. A. Massive diamictite facies. B. Other facies. (see Table 3 for facies abbreviations.)

and the data plotted as rose diagrams. Because the cores were not oriented, the diagrams have no directional control.

To test whether there was any significant preferred orientation, Chi-square tests were performed on the data, allowing us to decide whether there was a preferred grain orientation fabric at the 0.01 and 0.05 significance levels (Figs. 16 and 17).

The three samples from massive diamictite at Site 739 (Fig. 17) and five of the eight samples at Site 742 (Fig. 16) showed no significant preferred orientation. Three other samples at Site 742 , at depths of 24,143 , and 197 mbsf, each had a significant preferred orientation at the 0.01 level (Fig. 16); in these cases the preferred orientation could also be observed. There are no differences, on the basis of these limited data, between clastrich and clast-poor diamictites.

\section{STRATIGRAPHY}

The glacial stratigraphy of the five Prydz Bay drill sites was described individually in detail in the Leg 119 Site Reports (Barron, Larsen, et al., 1989). Only the main lithological data are summarized here. However, a comprehensive account is given in Appendix G, where lithological units are linked to other parameters, i.e. geotechnical, downhole logging (Sites 742 and 739 only) and seismic reflection data (Figs. 18 and 19). The strata are described from the inner shelf outward. The sites are discussed within the framework of three main seismically defined units: (1) an upper, flat-lying sequence that extends across the whole shelf and passes into prograding sediments at the present continental slope; (2) an upper, steeply-inclined prograding se- 


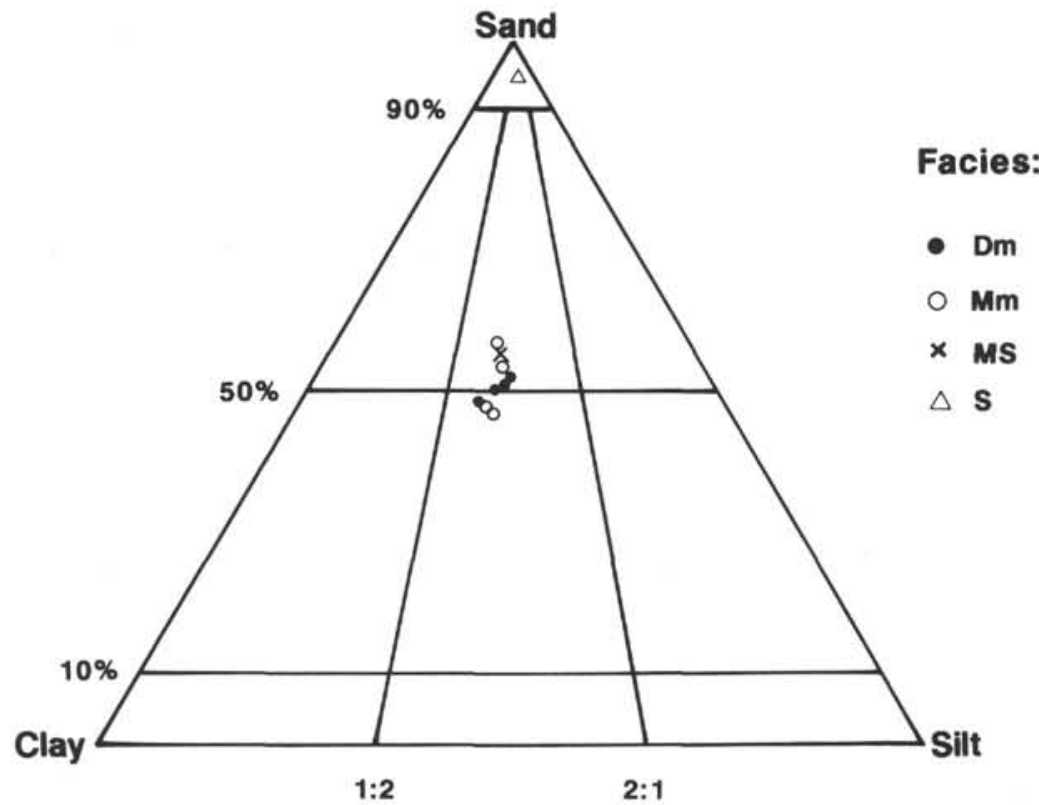

Figure 10. Triangular plot of the sand-sized and finer fraction according to facies, Site 743 (see Table 3 for facies abbreviations).

quence, unconformably below the flat-lying sequence and present only at Site 739; and (3) a lower, gently dipping prograding sequence that underlies the upper prograding sequence at Site 739 , and the flat-lying sequence at Site 742 . Other prograding units, not drilled, occur seaward of Site 739.

\section{Site 740}

Subunit IA (0 to about $15 \mathrm{mbsf}$ ) consists of diatom ooze with minor radiolarians, silicoflagellates, clay, and silt, but no gravel. The ooze is interbedded with structureless silty, sandy clay that contains pebbles and coarse sand, but few diatoms. The age is probably Holocene.

Subunit IB (15-56 mbsf) is represented by crystalline boulders which prevented any recovery except for a few broken clasts. It is inferred that the bulk of the unrecovered material is a boulder-rich diamicton or conglomerate of Pleistocene age.

A red bed sequence occurs below Subunit 1B (Turner, this volume).

\section{Site 741}

Unit I (0-0.7 mbsf) comprises diatom ooze, with terrigenous clay, silt, a few pebbles, and minor radiolarians, silicoflagellates, and sponge spicules.

Unit II (0.7-4.1 mbsf) is a normally consolidated sandy mud with diatoms and a few shells. Both Units I and II are probably of Holocene age.

Unit III (4.1-24 mbsf) from drilling behavior, represents the same lithology as Subunit IB at Site 740; a Pleistocene age is probable.

\section{Site 742}

Unit I (0-5.4 mbsf) comprises two subunits. Subunit IA (top) consists of $7 \mathrm{~cm}$ of diatomaceous sand-silt of probable Holocene age. Subunit IB is a massive diamicton, with a gravel content of $5 \%-10 \%$. Some diatoms are present, as well as occasional radiolarians. A late Pliocene-Quaternary age has been assigned to this unit.

Unit II (5.4-115.2 mbsf) is a massive diamictite with up to $15 \%$ gravel. This unit has also yielded a late Pliocene-Quaternary age.
Unit III (115.2-134.4 mbsf) comprises four subunits: Subunit IIIA is an 8.5 -m-thick massive to weakly stratified diamictite with $1 \%-10 \%$ gravel. Subunit IIIB is represented by a $60-$ $\mathrm{cm}$-thick diatomite with some sand and mud of terrigenous origin. Its age is probably early Pliocene. Subunit IIIC consists of $5.4 \mathrm{~m}$ of weakly stratified diamictite, sandstone and clayey siltstone. Subunit IIID is a large gneiss boulder, measuring $62 \mathrm{~cm}$ downcore.

Unit IV (134.4-172.5 mbsf) is a massive (locally weakly stratified) diamictite, with $1 \%-7 \%$ gravel. Thin layers with minor carbonate occur toward the base. The lack of fossils precludes determination of age.

Unit $V(172.5-304.3 \mathrm{mbsf})$ is a massive diamictite with $1 \%$ $5 \%$ gravel and of a lighter color than overlying diamictite. Rare shell fragments and sporadic carbonate layers also occur. Rare calcareous nannofossils indicate a late Eocene to Oligocene age.

Unit VI (304.3-316.0 mbsf) comprises three subunits. Subunit VIA has $3.2 \mathrm{~m}$ of stratified sandy mudstone with up to $7 \%$ gravel. The few shell casts and minor plant debris that have been noted have not proved datable. Subunit VIB consists of $5.8 \mathrm{~m}$ of mainly massive diamictite with $1 \%-5 \%$ gravel. Subunit VIC is a complex, deformed sequence and occupies the bottom $2.7 \mathrm{~m}$ of the hole. It consists of whitish sand, carbonaceous siltstone and stratified diamictite with $1 \%$ gravel, $3 \%-5 \%$ organic debris and fragments of lignite. The subunit has undergone extensive soft-sediment deformation.

\section{Site 739}

Unit I (0-24.1 mbsf) consists of massive diamicton and sandy mud. The proportion of gravel clasts is $1 \%-10 \%$ in the former and less than $1 \%$ in the latter. There is a variable proportion $(5-35 \%)$ of diatoms and minor amounts of radiolarians and foraminifers, and echinoderm fragments. A biostratigraphic age of late Pliocene to Quaternary age has been assigned to this unit, the uppermost oozes probably being of Holocene age.

Unit II (24.1-173.6 mbsf) is dominated by compacted, friable, massive diamictite with $5 \%-20 \%$ and with a diatom content exceeding $20 \%$ in places. The age of this unit is defined paleontologically as late Miocene to early Pliocene. 

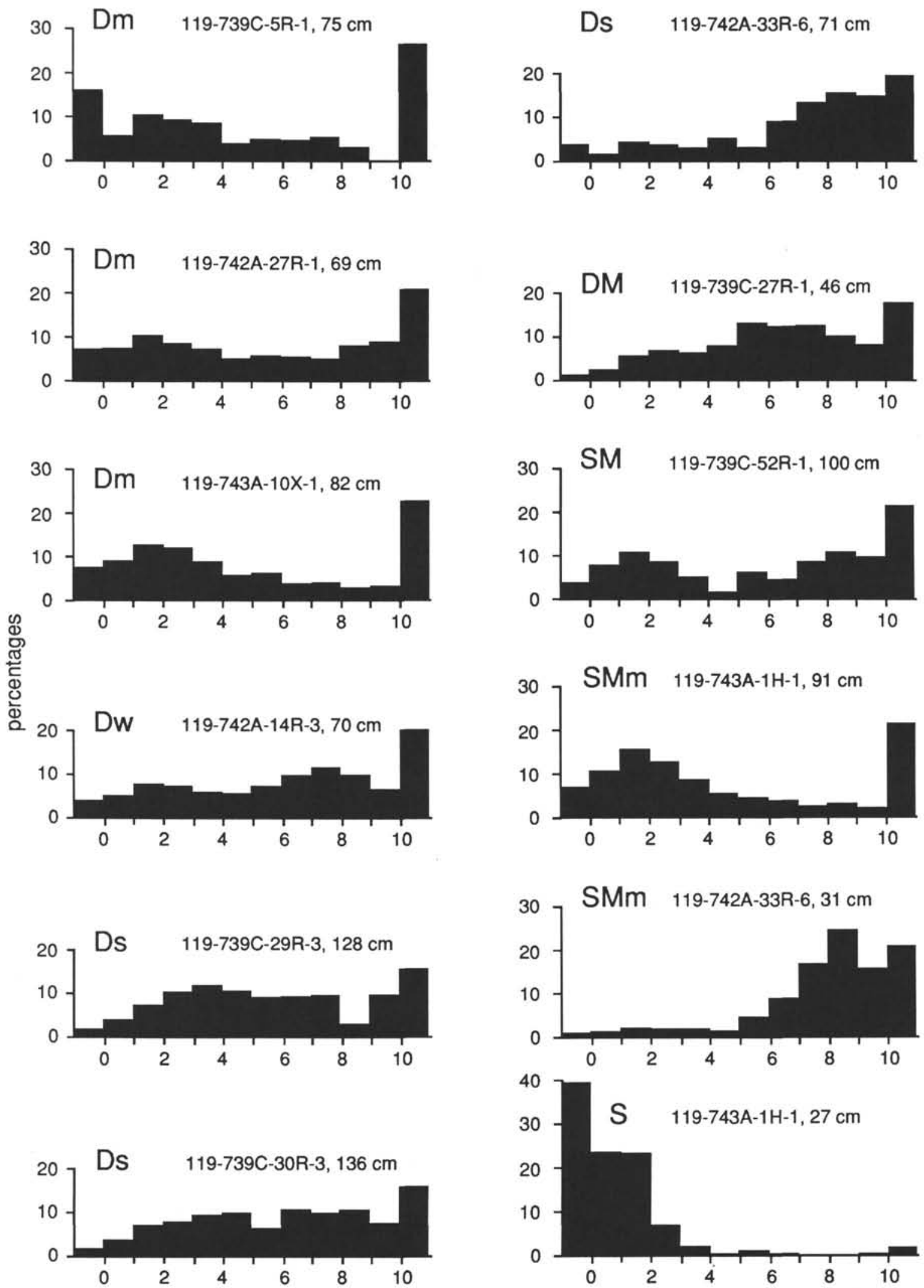

Phi units

Figure 11. Histograms of sand-sized and finer fraction of representative samples of the principal lithofacies in Sites 739, 742, and 743. Facies abbreviations are as in Table 3. Phi units represent the following size classes: sand $<4 \phi(2 \mathrm{~mm}-63 \mu \mathrm{m})$; silt 4$8 \phi(63-4 \mu \mathrm{m})$; clay $8-11 \phi(4-0 \mu \mathrm{m})$. The peaks at the right of most histograms are an artifact of the analysis in which all sizes $>10 \phi$ are grouped together. 

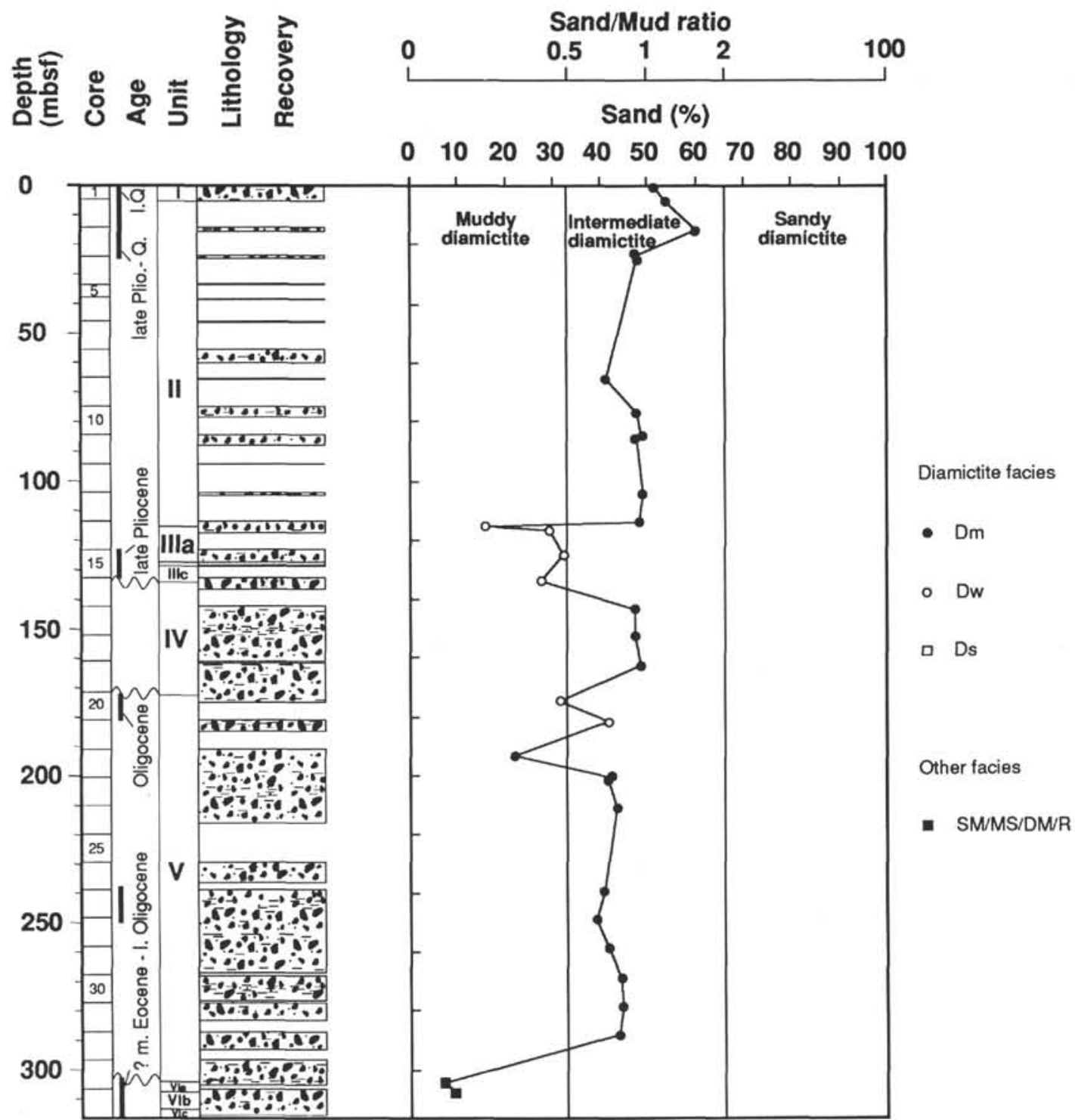

Figure 12. Ratio of sand to mud, plotted according to depth and facies; Site 742. The range of different types of diamictite is according to the classification of Moncrieff (1989).

Unit III (173.6-267.2 mbsf) comprises three subunits. Subunit IIIA comprises $19.3 \mathrm{~m}$ of moderately well- to weakly stratified diamictite and minor mudstone. The gravel content varies from $3 \%-10 \%$. Soft sediment deformation, graded bedding, bioturbation, and slickensided striations have also been noted. Subunit IIIB is a massive, diatomaceous sandy mudstone.

Subunit IIIC (69.1 m thick) consists of alternating beds of massive and weakly stratified diamictite with up to $10 \%$ gravel and up to $40 \%$ diatoms and scattered shells. Slump structures are well developed. The biostratigraphic age ranges from possible late Eocene to early Oligocene, but Sr-isotopic ages are in the range 23-28 Ma (late Oligocene).

Unit IV ( 267.2-315.7 mbsf) is a massive diamictite with gravel content ranging from $1 \%-10 \%$. Small shell fragments occur sporadically, and there are minor silicoflagellates, radiolarians, and nannofossils. The age, based on diatom stratigraphy, is early Oligocene, although an Sr-isotope value of $29 \mathrm{Ma}$ indicates a late Oligocene age.

Unit V (315.7-486.8 mbsf) consists of massive diamictite, although lighter colored than the overlying diamictites. It con- tains calcite-cemented zones and 2\%-5\% gravel. Age constraints are poor although nannofossils suggest a possible middle Eocene to Oligocene age

\section{Site 743}

Unit I (0-0.5 mbsf) is a moderately well sorted loose sand, mixed with diatom ooze. Near its base this unit contains $20 \%$ of foraminifera.

Unit II (0.5-15.8 mbsf) is a structureless clayey silt or silty clay, with up to $1 \%$ gravel. It is interbedded with gravelly sand with foraminifera.

Unit III (15.8-98.1 mbsf) appears to be a massive diamicton from assemblages of broken clasts. The sequence has been dated as Pliocene to Quaternary.

\section{Hiatuses}

The recovered sequence reveals few clear sharp breaks of sedimentation, but the unrecovered intervals, on the basis of other evidence such as downhole logging and physical properties, al- 

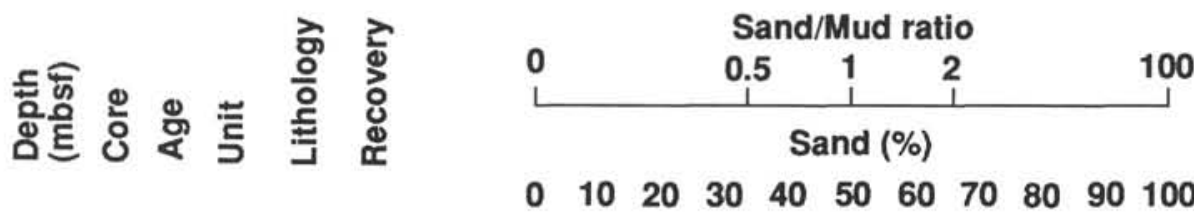

0
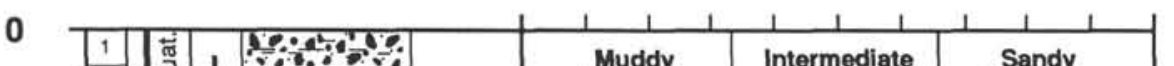

50

50
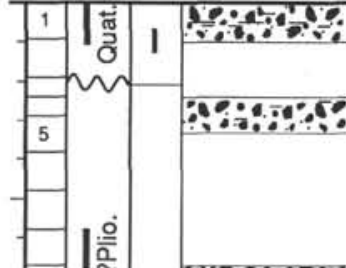

a:39:?:?

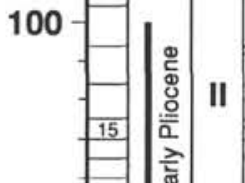

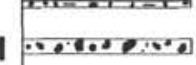

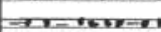

nosen.

150

खण

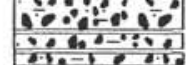

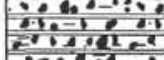

$\infty+\infty=$

25 III

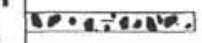

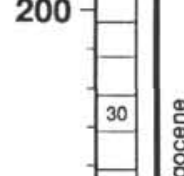

itib

0.0 .0 .0 .90

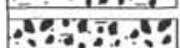

$0.9 \cos ^{3}$

250

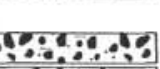

- $2: 1-196$

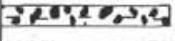

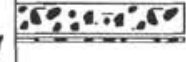

300

IV

$\therefore .8 .91 .46$

$\because 8.8 .8,-80^{2}$

$350-\square=0$

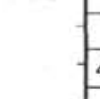

45 ,

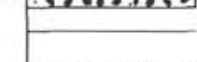

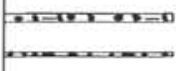

400
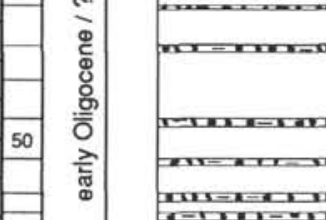

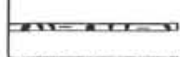

$\frac{6}{605-60}$

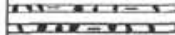

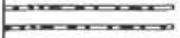

ond n-t.

$+\infty \times$

diamictite

diamictite

Sandy

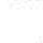

$550-55$

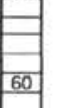

(2)

Figure 13. Ratio of sand to mud, plotted according to depth and facies; Site 739. The range of different types of diamictite is according to the classification of Moncrieff (1989). 


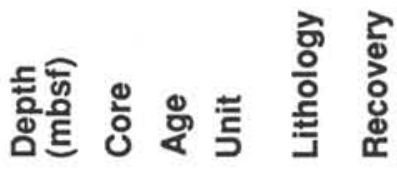

Shape of gravel clasts

(\%)

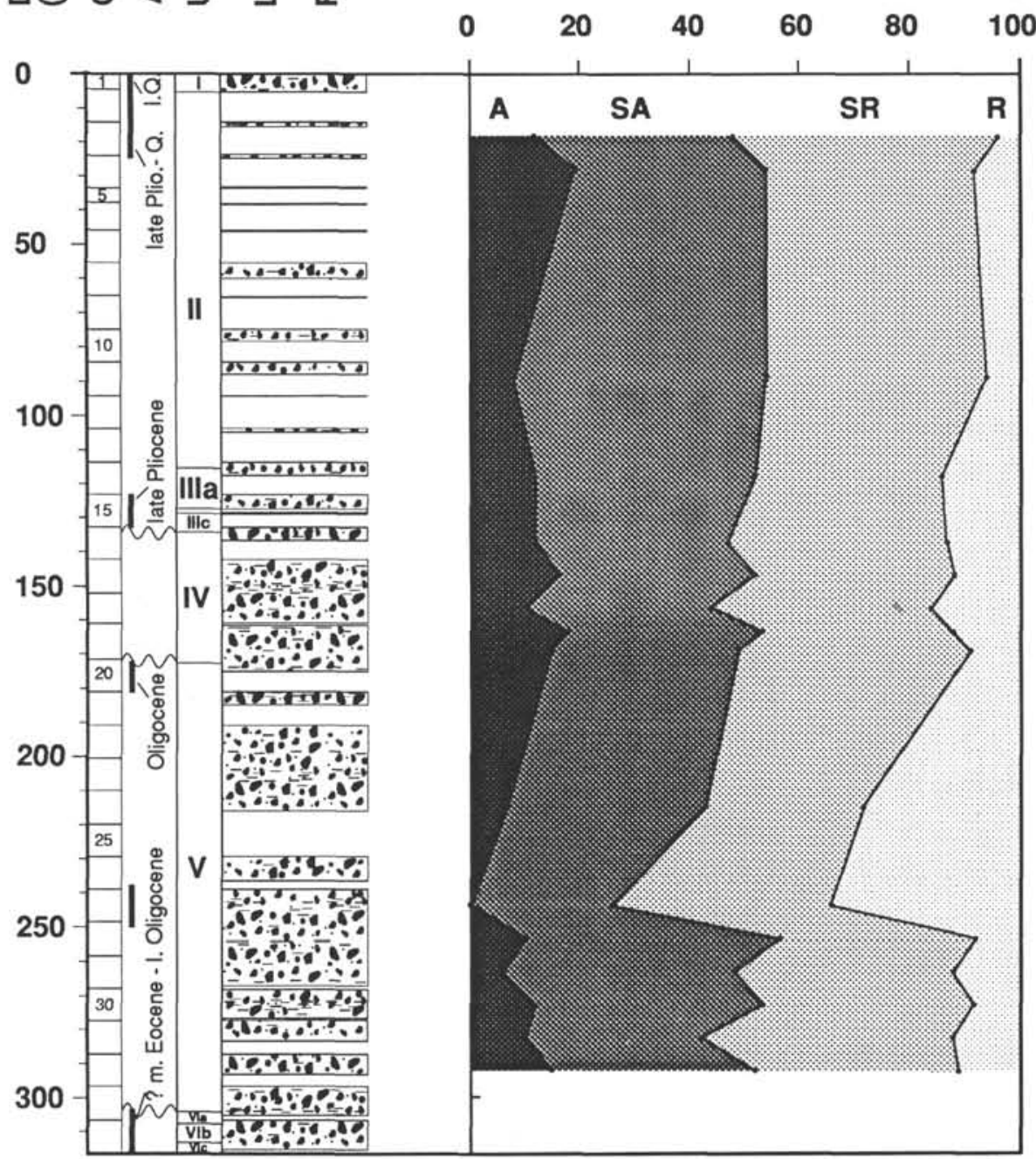

Figure 14. Plot of relative proportions of the different clast shapes with depth, Site 742. $\mathrm{A}=$ angular, $\mathrm{SA}=$ subangular, $\mathrm{SR}=$ subrounded, and $\mathrm{R}=$ rounded.

most certainly hide such breaks. Identified hiatuses (Figs. 18 and 19) are discussed in this section.

Sites 739 and 742 are the only two sites that record the biostratigraphically earlier late Eocene-Oligocene prograding part of the glacial record. From seismic data, Site 742 represents the lower part of the Oligocene sequence and Site 739 the upper part, with the several hundred meters of sediment in between not cored. The lower part of Site 742 (Unit VI) represents just the upper few meters of a distinct seismic unit that has an unconformable top and extends down below the drill hole to 415 mbsf. This hiatus at 304.3 mbsf, which is of unknown duration, separates deformed sediments of mixed glacial and nonglacial origin from a massive diamictite sequence (Unit V), characterized by lower clast content and scattered carbonate-cemented layers. At Site 742 , Unit V is cut off by an unconformity at 172.5 mbsf, but seismic data indicates that this unit continues upward into Unit V at Site 739, where it too is topped by an unconformity. At the latter site the unconformity is not observable directly in the core. The unconformity is estimated from seismic data to be at a depth of $316 \mathrm{mbsf}$, and it separates the more gently dipping sequence from the steeper prograding sequence. The visual impression of a change in composition at this boundary is confirmed by changes in the carbonate, opal, and sulfur content.

Overlying sediments, also of Oligocene age, occur in Units IV (massive diamictite) and III (mixed facies, including stratified diamictite) at Site 739 . The boundary between these two units is sharp, and different sources for the sediment are suspected from the logging data. The variations in the degree of compaction suggest a number of hiatuses in excess of those indicated by slickensides in the core.

The entire Oligocene sequence is truncated by a major regional unconformity, which at Site 739 probably represents a time gap defined paleontologically to last from late Oligocene to mid-Miocene time. At Site $\mathbf{7 4 2}$ the unconformity-bounded Unit IV is undated, but forms part of the flat-lying sequence. Above, the oldest sediments of Unit III are of late early Pliocene to early late Pliocene age. The flat-lying sequences thus embrace the interval from late Miocene to Quaternary, and within it are a number of lithologically and biostratigraphically 


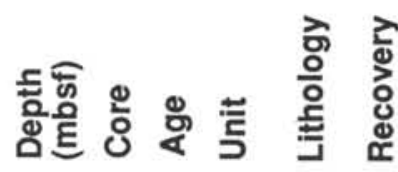

Shape of gravel clasts

(\%)

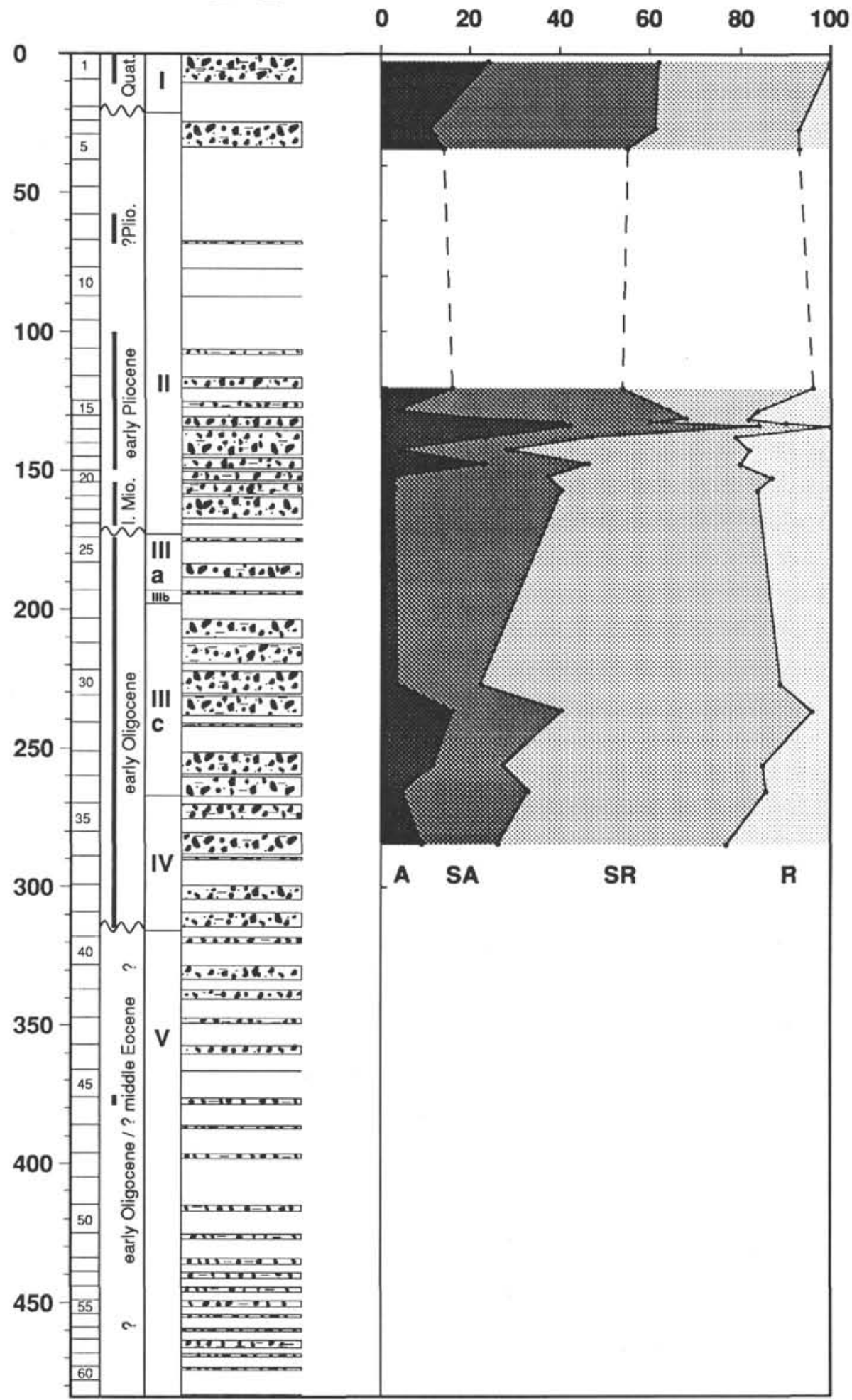

Figure 15. Plot of relative proportions of the different clast shapes with depth, Site 739. $A=$ angular, $\mathrm{SA}=$ subangular, $\mathrm{SR}=$ subrounded, and $\mathrm{R}=$ rounded. 


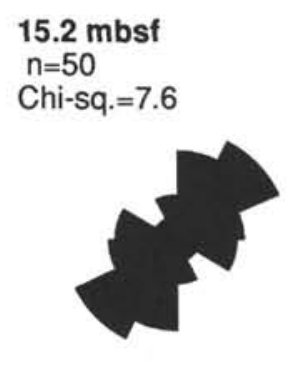

$$
\begin{aligned}
& \sim 24 \text { mbsf } \\
& \mathrm{n}=50 \\
& \text { Chi-sq. }=24.9
\end{aligned}
$$

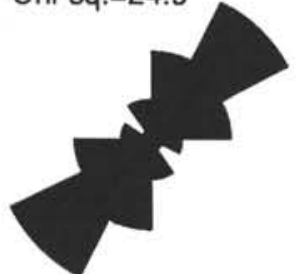

$84.7 \mathrm{mbsf}$

$\mathrm{n}=50$

Chi-sq. $=7.8$

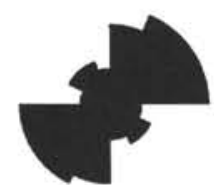

Facies: IDm; intermediate, clast-rich, massive diamictite

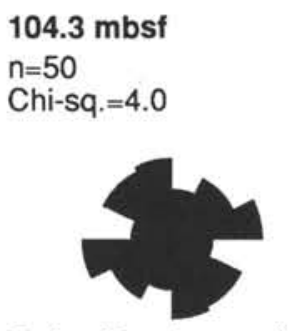

Facies: IDm; intermediate, clast-rich, massive diamictite

\section{8 mbsf \\ $\mathrm{n}=50$}

Chi-sq. $=1.6$

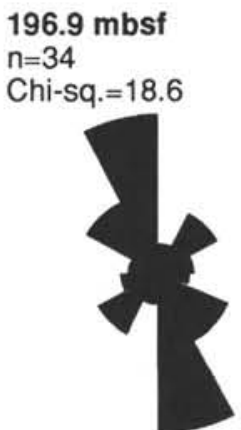

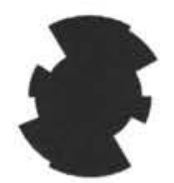

Facies: IDm; intermediate,clastpoor, massive diamictite
142.8 mbsf

$\mathrm{n}=62$

Chi-sq. $=15.0$

Facies:ID m; intermediate clast-poor, massive diamictite

Figure 16. Rose diagrams of grain orientation on horizontally cut faces of core, Site 742. $\mathrm{Chi}^{2}>15$ is significant at 0.01 confidence limit and $>11$ at 0.05 limit.

poorly-defined hiatuses, evident in both the downhole logging and physical-properties data. Variations in loading history in Units II and III at Site 742 and Unit II at Site 739 suggest periodic ice expansion events, which probably created the hiatuses (Solheim et al., this volume).

The middle of Unit II at Site 739 and Unit II at Site 742 show a major change in hardness, logging characteristics, and percent of recovery of massive diamictite (Barron, Larsen, et al., 1989), suggesting a particularly significant loading event or lithological change, but the age of this hiatus cannot be ascertained. Similar strata to these upper sediments also occur at Sites 740 and 741. A few meters of unconsolidated diamicton, dated as late Pliocene to Quaternary, are present, but a late Pleistocene age is considered most likely if one considers the effect of ice advances to the shelf break during most of Quaternary time, and the thick build up of sediment evident on the continental slope. Thus, the Quaternary record on the shelf is probably incomplete, with Pleistocene glaciation probably responsible either for stripping off earlier sediments or for burying the underlying sediments and overconsolidating them. The shape of present-day ice sheet profiles and theoretical models (Paterson, 1981) suggest that the ice could have been little more than a few hundred meters thick at the shelf edge, or otherwise the ice would have been unstable.

Finally, a marked change to sediments containing a significant diatom ooze component occurs within a few meters of the surface at Sites 741, 742, and 743, and at $23 \mathrm{mbsf}$ at Site 740 . From ${ }^{14} \mathrm{C}$ dating by Domack and Jull (this volume), the diatom ooze-rich sediment spans the Holocene Epoch, and the hiatus therefore probably represents the transition from the Pleistocene glacial to Holocene reduced glacial conditions as of today.

\section{Correlation with Seismic Units and "Architecture" of the Shelf}

Several acoustic units of the continental shelf (PS.1-PS.6) and continental slope (PD.1-PD.5) were defined by Stagg (1985) and refined by Cooper et al. (this volume). They form the basis for broad lithostratigraphic correlation throughout the region.

Acoustic unit PS. 1 is a flat-lying unit lying directly below the seafloor, unconformably overlying older dipping sequences (Fig. 1B). Unit PS.1 is characterized by chaotic, incoherent reflections with a number of extensive strong reflection horizons. It covers the whole of the surveyed part of the shelf and varies in thickness from a few meters in the inner and western parts of 


\section{$25.3 \mathrm{mbsf}$}

Facies: IDm (intermediate clast-rich massive diamictite)

$n=31$

Chi-sq. $=4.8$

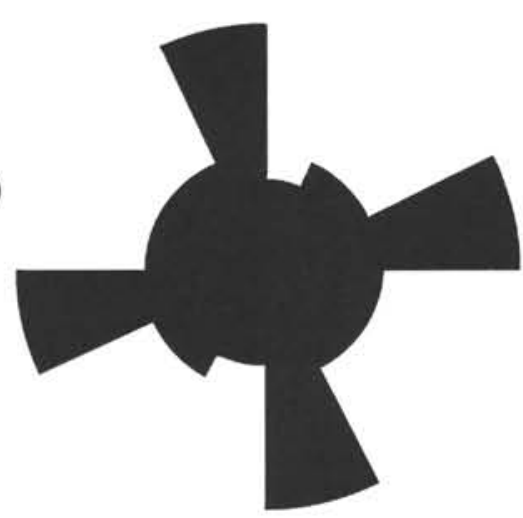

\section{0 mbsf}

Facies: IDm (intermediate clast-rich massive diamictite)

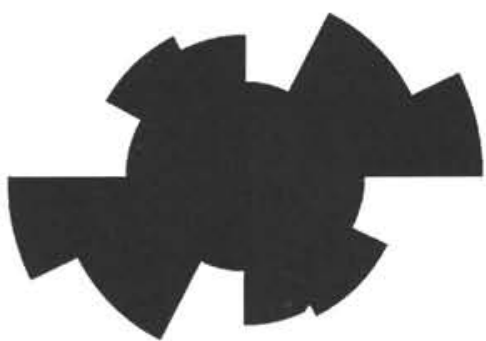

\section{6 mbsf}

Facies: MDm (muddy clast-rich massive diamictite)

$\mathrm{n}=50$

Chi-sq. $=9.0$
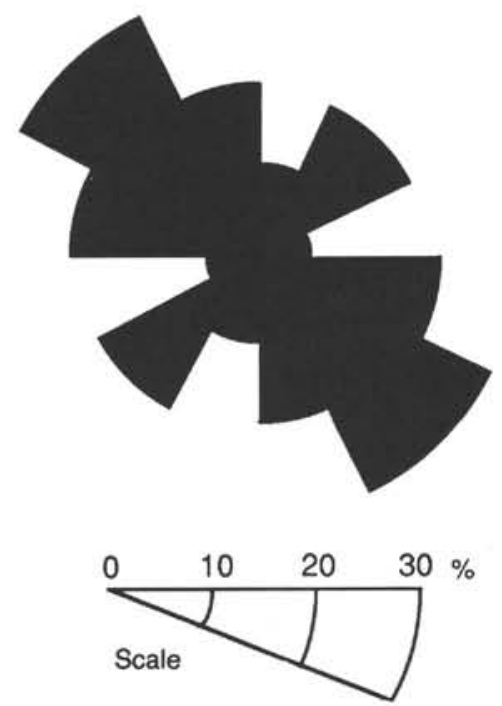

Figure 17. Rose diagrams of grain orientation on horizontally cut faces of core, Site $739 . \mathrm{Chi}^{2}>15$ is significant at 0.01 confidence limit and $>11$ at 0.05 limit.

Prydz Bay to nearly $250 \mathrm{~m}$ under the banks in the outer and eastern parts of the bay. However, beneath the deep transverse Prydz Channel this unit appears to be thin or missing (Cooper et al., this volume).

PS. 1 was sampled at all Prydz Bay sites except Site 743. It is represented by lithologic Unit I at Site 740, Units I-III at Site 741, Units I-IV at Site 742, and Units I and II at Site 739. At the continental shelf edge, PS.1 can be traced into the outermost part of the prograding wedge, the top of which was recovered at Site 743 on the continental slope.

Stagg's (1985) unit PS.2 is divided into an upper and lower subunits, PS.2A and PS.2B, respectively. The upper one corresponds to both the upper prograding unit and the lower pro- grading unit, whereas PS.2B represents the upper part of the pre-glacial sequence (Cooper et al., this volume).

The upper steeper prograding unit was sampled at Site 739 and embraces lithologic Units III and IV. It was also sampled on the continental slope at Site 743 . This steeper prograding unit underlies the outer $30 \mathrm{~km}$ of the shelf, beneath the outer parts of both the Four Ladies Bank and the transverse channel. The width of the prograded part of the shelf is $\approx 30 \mathrm{~km}$ at the drill sites, but increases to $50 \mathrm{~km}$ at the mouth of the Prydz Channel (Cooper et al., this volume). Thus, the lobate extension of the shelf northward (Fig. 1) is due to an increased rate of progradation of the mouth of the channel. Some reflectors in the cover unit (topsets) can be traced directly into reflectors in the 


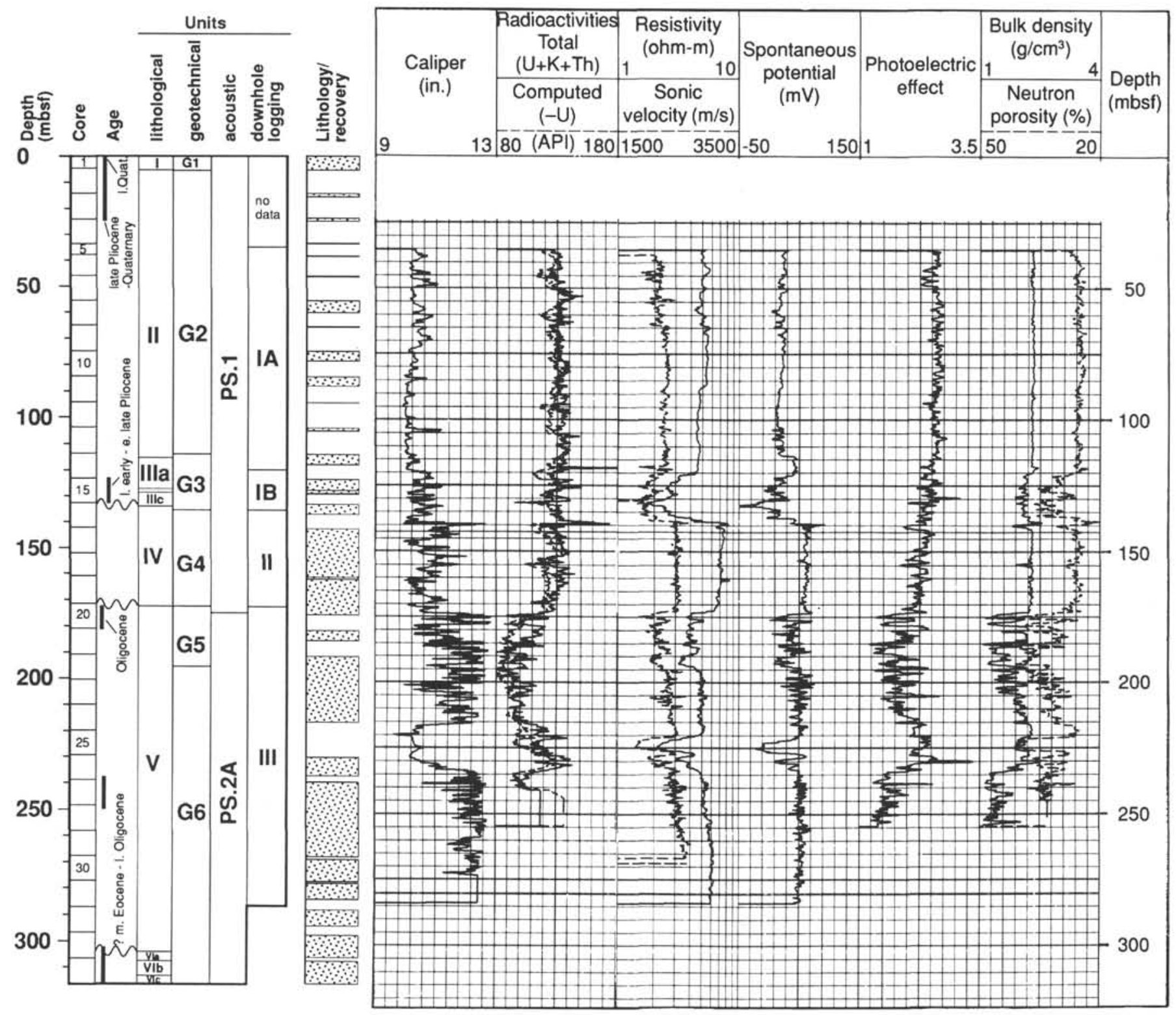

Figure 18. Summary stratigraphic log for Site 742, showing lithological, geotechnical, acoustic, and downhole logging units. To the right of the log are plotted a variety of downhole logging parameters: caliper, total radioactivity, resistivity, sponaneous potential, photoelectric effect, bulk density, and neutron porosity.

upper prograding units (foresets) indicating episodes of building up of the outer shelf, at the same time as progradation of the continental slope (Barron, Larsen, et al., 1989; Mizukoshi et al., 1988). Other subunits within the upper prograding unit are clearly truncated by the upper flat-lying unit, which may indicate episodes of either progradation without contemporaneous build up or subsequent erosion. Seaward of Site 739, a number of discrete sedimentary packages are observed within the upper prograding unit, one of which is about $10 \mathrm{~km}$ across and appears to have undergone wholesale slumping, indicating partial collapse of the continental shelf margin.

The upper prograding unit grades downslope into acoustic unit PD.2, which, based on the seismic evidence of Stagg (1985), is characterized by slump structures in water depths exceeding $1000 \mathrm{~m}$.

The gently dipping lower prograding unit forms the lower part of acoustic Unit PS.2A of Cooper et al. (this volume). It is represented by lithologic Units IV and V at Site 742 and Unit V at Site 739.

\section{PROCESSES AND ENVIRONMENTS OF DEPOSITION}

Sites 739,742 , and 743 and the upper parts of Sites 740 and 741 are dominated by diamicts of various types and attest to glaciogenic sedimentation almost without interruption on the basis of recovered core. To facilitate the discussion, a summary of terminology of the criteria for identifying glaciogenic sediments and of current knowledge concerning processes in glaciomarine environments is given in the following.

\section{Genetic Classification of Glaciogenic Deposits}

Glacial environments are characterized by a wide range of facies that reflect interaction of glacial deposition with fluvial, aeolian, lacustrine, marine, and biogenic processes. However, only 

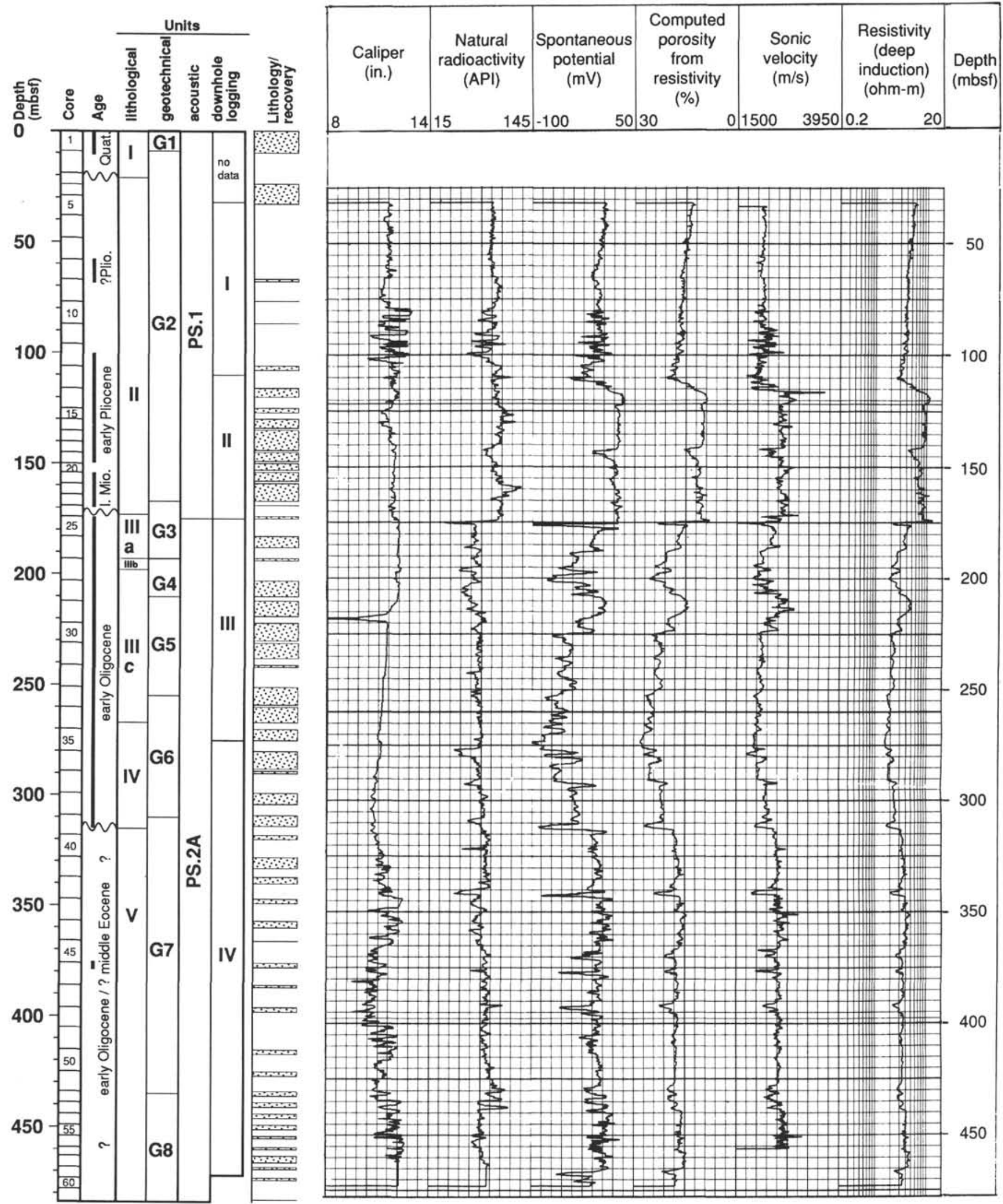

Figure 19. Summary stratigraphic log for Site 739, showing lithological, geotechnical, acoustic, and downhole logging units. To the right of the log are plotted a variety of downhole logging parameters: caliper, natural radioactivity, sponaneous potential, sonic velocity, and resistivity. 
the last three processes appear to have been significant in Prydz Bay.

The terminology of terrestrial glaciogenic sediments, following many years of debate by the INQUA Commission on the Genesis and Lithology of Quaternary Glacial Deposits, is now relatively well defined (Dreimanis, 1988). In contrast, there is no universally agreed scheme for marine glacial sediments. As a baseline we use the definition of Borns and Matsch (1988): "glaciomarine (glacial-marine, glaciomarine) sediment includes a mixture of glacial detritus and marine sediment deposited more-or-less contemporaneously. The glacial component may be released directly from glaciers and ice shelves, or delivered to the marine depositional site from those sources by gravity, moving fluids or iceberg rafting." Our own classification has evolved following work on glaciomarine sediments of various ages deposited in different types of marine setting (Barrett et al., 1989a, 1989b; Hambrey et al., 1989b; Moncrieff and Hambrey, 1990) and takes into account elements of other classifications (e.g., Anderson et al., 1983; Anderson and Molnia, 1989; Elverhфi, 1984; Eyles et al., 1985; Gravenor et al., 1984; Goldthwaite and Matsch, 1988; Dreimanis, 1988). The principal characteristics of terrestrial glaciogenic sediments are presented by Dreimanis (1988).

Lodgement till (Dreimanis, 1988) is "deposited by plastering on of glacial debris from the sliding base of a moving glacier by pressure melting and/or other mechanical processes." The ice may be grounded below sea level, for example, as the inner part of an ice shelf.

Melt-out till (Dreimanis, 1988) is "deposited by slow release of glacial debris from ice that is not sliding or deforming internally."

Basal till embraces both lodgement and melt-out tills, as it is derived from the debris-rich sole of a glacier.

Waterlain till is deposited by continuous "raining out" of basal debris from a floating glacier tongue or an ice shelf just seaward of the grounding line or zone, with little or no reworking by bottom currents. The marine component is negligible; therefore, it is inappropriate to classify the sediment as glaciomarine. Floating glaciers today are generally of the subpolar or polar type, with ice mainly below the pressure melting point. Deposition of waterlain till is a process that has not been observed yet, owing to the difficulty of access to sites where continuous rain out of debris is likely to occur. However, in the context of an ice mass decoupling from its bed at a paleoslope break we consider this to be an important process and one that has not been adequately considered in earlier classifications.

The preceding use of the term "till," which embraces glacial debris deposited through a water column (waterlain till), is in keeping with an earlier INQUA classification proposed by Dreimanis (1976) and as used by Gibbard (1980) for Quaternary deposits and many authors for pre-Pleistocene glaciogenic sediments (Hambrey and Harland, 1981). Recent proposals (Dreimanis, 1988) limit "waterlain till" to deposition in only a few meters of water, but embrace both massive and stratified varieties. In this sense it is equivalent to the term "undermelt diamicton" of Gravenor et al. (1984), but we are unhappy at mixing genetic and nongenetic terms. Kellogg and Kellogg (1988) use the term waterlain till in the above sense for Antarctic sediments. Some workers on contemporary glacial sediments (e.g., Lawson, 1981) restrict the term "till" to a sediment deposited directly from ice without subsequent disaggregation and flow, so as to exclude any glacial sediment deposited in water. However, the INQUA definition is broad enough to include the waterlain variety of till, if it has not been winnowed during deposition (as indicated by an absence of current structures), or if no marine sediment has been added.
Proximal glaciomarine sediment is transitional with waterlain till and contains a high proportion of ice-rafted or "rainout" material (with about 1\%-5\% gravel) from calving or floating ice. Grounded ice may generate dirty icebergs by which debris may also be added to the marine environment. The background marine sediment is probably derived mainly from plumes of sediment carried in glacial meltwaters and from biogenic material such as diatoms. Proximal glaciomarine sediment is broadly equivalent to the "transitional glacial-marine sediment" of Anderson et al. (1983).

Distal glaciomarine sediment consists predominantly of marine sediments of terrigenous origin brought to the site in suspension as meltwater-generated sediment plumes or underflows, together with deposits of biogenic origin. The biogenic component, which may be dominant, consists principally of diatoms. The ice-rafted component is minor and is represented by less than $1 \%$ gravel. This type of sediment is approximately equivalent to Anderson et al.'s (1983) "compound glacial-marine sediment."

The preceding classification refers to sediments remaining unmodified after deposition. As soon as glaciogenic sediments are reworked by current action, slumping, or debris flowage, we consider them as nonglacial. The role of reworking processes in Antarctic glaciomarine sediments has been discussed by Anderson et al. (1980a, 1980b, 1983), Wright and Anderson (1982), Wright et al. (1983), and Elverh $\phi$ i (1984).

In this context the terms need not have direct implications for the proximity of land, but refer instead to the concentration of floating debris-rich ice and the relation of the resulting sediment to input of marine sediment. Drift paths of icebergs, for example, may profoundly affect the facies deposited near an ice margin (Moncrieff and Hambrey, 1990), whereas winnowing and removal of fines may increase the concentration of icerafted debris in a distal marine setting.

Compared with the terrestrial glacial environment, relatively little is known of the glaciomarine environment, although the work of several groups (e.g., Domack et al., 1980; Anderson et al., 1983; Barrett et al., 1983, 1989a; Robinson et al., 1987; Fütterer et al., 1988; Griffith and Anderson, 1989) in the Antarctic, together with studies of well-exposed older sediments, has provided a basis for assessment of the Prydz Bay glaciogenic sediments.

\section{Interpretation of Prydz Bay Sediments}

The glacial character of the sediments is indicated by the poor sorting, wide range of grain shapes (rounded to subangular with predominance of the subrounded and subangular classes), mixed clast lithologies, a few dropstones, and the textural and mineralogical immaturity. Striated stones are rare because the source rocks are coarse-grained, but some clasts carry weakly developed facets. Clasts of coal and fine-grained amphibolite do bear fine striations and have well-developed facets; some also have bullet-nosed shapes. All these are features typical of subglacial transport. However, fine-grained lithologies are volumetrically unimportant as clasts.

\section{Interpretation of Individual Lithofacies}

The facies recovered in Prydz Bay can be considered in terms of a simple qualitative ice shelf-grounded ice model (Fig. 20). We consider this to be the most appropriate model to explain the Prydz Bay sediments. However, we stress that in the absence of direct observations of sedimentary processes beneath ice shelves, the model is based solely on inference. Massive diamicton and diamictite $(\mathrm{Dm})$ are the dominant lithologies at Sites 742 and 739, and most are interpreted as waterlain tills (Figs. 21 and 22) because they are totally homogeneous and lack bedding and oc- 


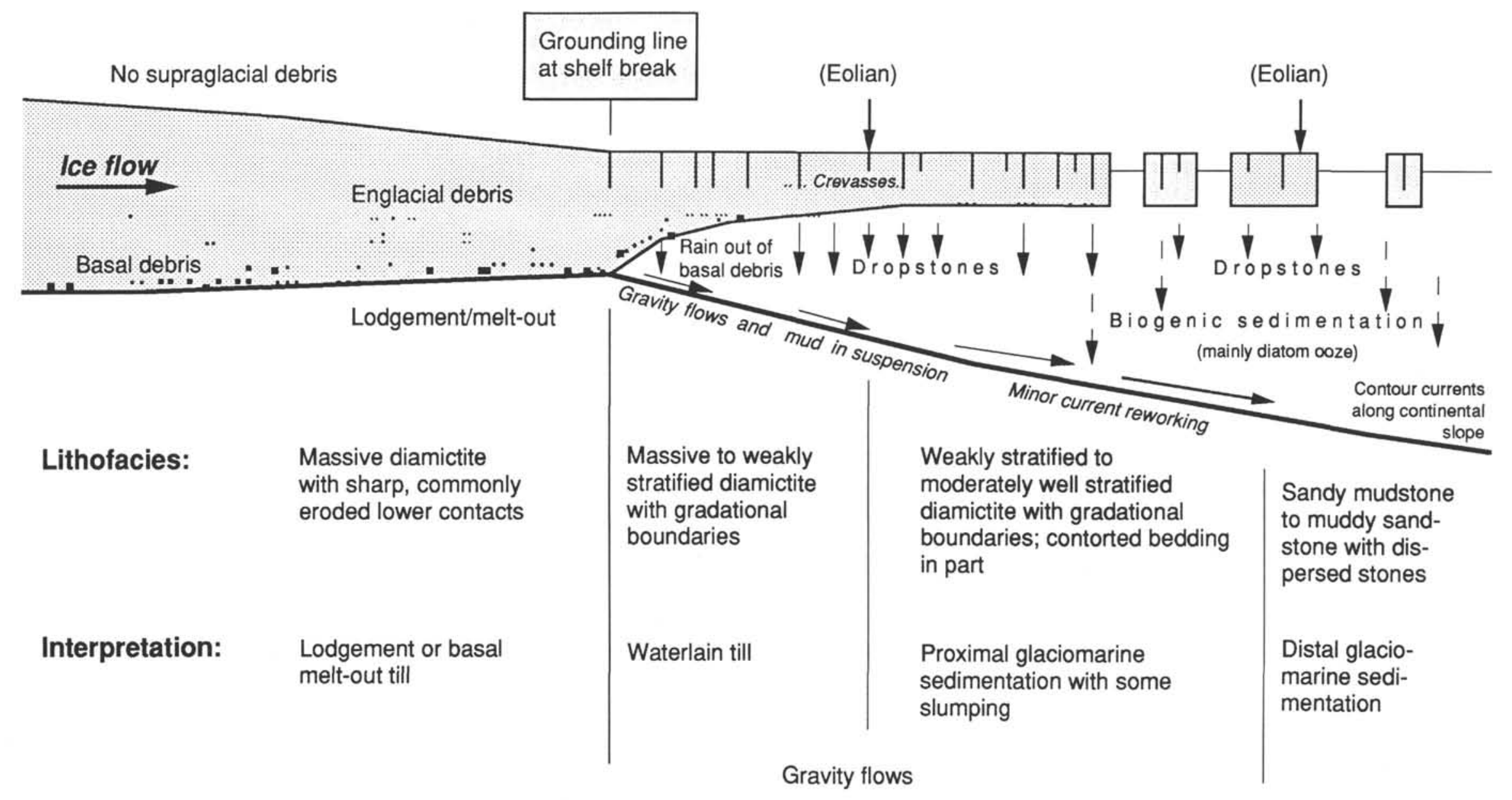

Figure 20. Generalized model illustrating principal sedimentary processes and resulting facies in a polar glaciomarine setting where the grounding line is situated at the shelf edge. 


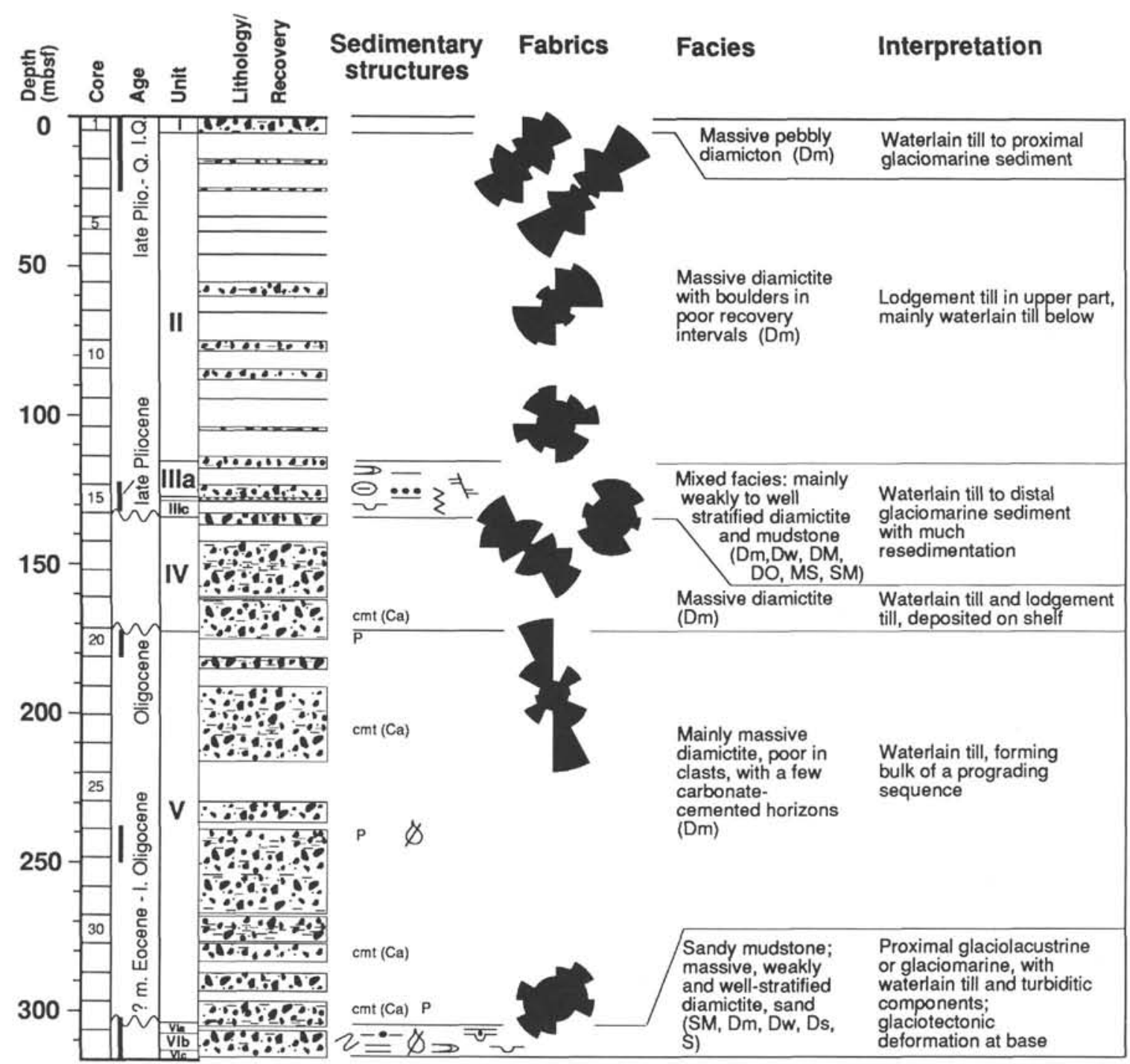

Sedimentary structures

weakly stratified: horizontal, inclined
moderately stratified; horizontal, inclined stratified: horizontal, inclined
graded bedding (fining upwards)
cross-bedding
convoluted bedding

Figure 21. Stratigraphy, sedimentology, and interpretation of the succession cored at Site 742 .

cur in layers many meters thick. Beds of massive diamictite form gradational boundaries with weakly stratified diamictite. The massive variety also contains a few percent diatoms at many levels (Figs. 21 and 22) and a few shell fragments, some of which are intact. All this points to deposition by continuous rain out through a water column close to the grounding line of an ice stream or ice shelf, with little or no reworking by bottom currents. Moreover, grain fabrics measured in three cores at Site 739 and five at 742 show no significant preferred orientation (Figs. 17 and 16), which is characteristic of deposition in a ma- 


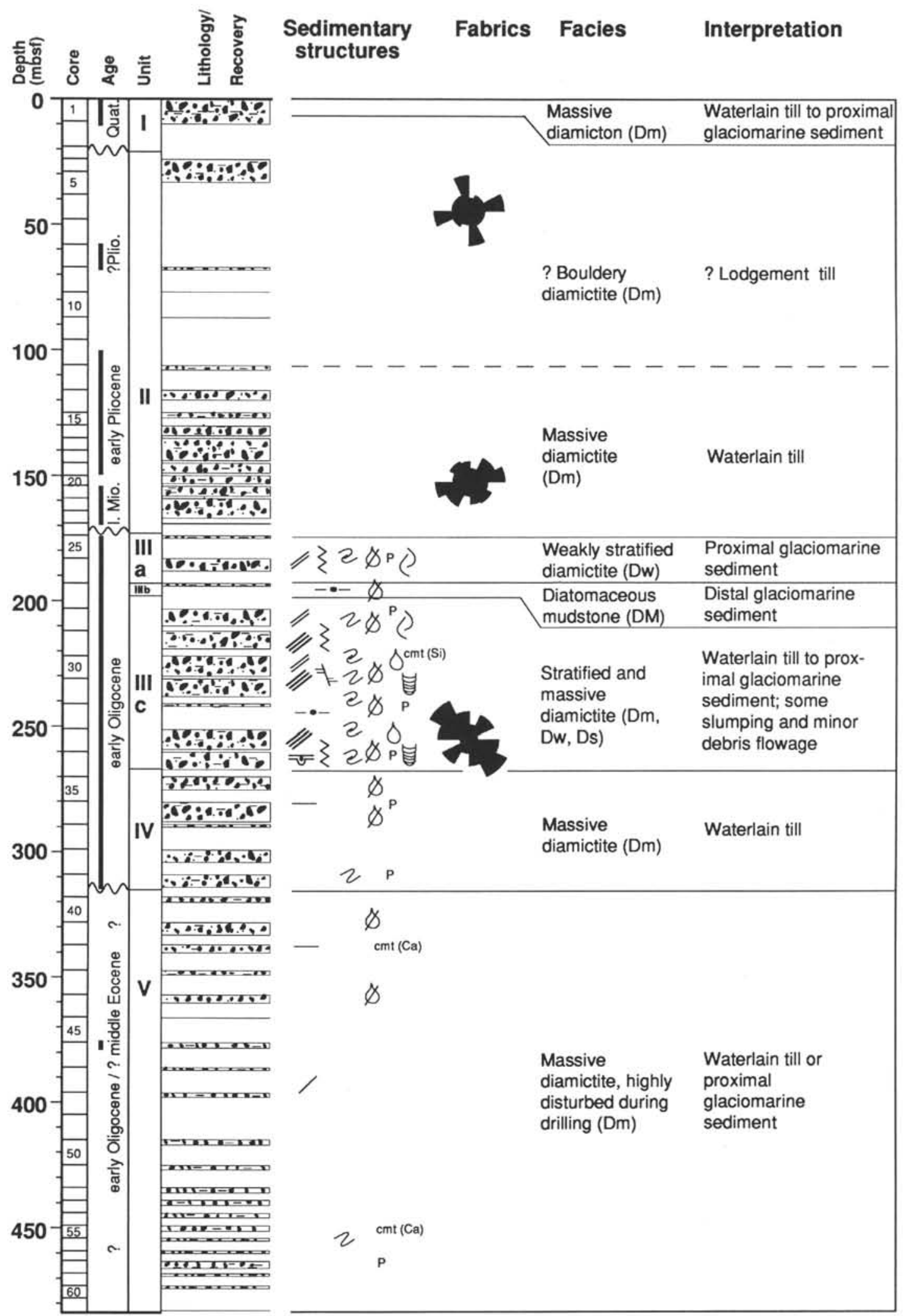

Figure 22. Stratigraphy, sedimentology, and interpretation of the succession cored at Site 739. Key as for Figure 21. 
rine setting (Domack and Lawson, 1985; Dowdeswell et al., 1985). Some of the supposed waterlain tills are situated in the highest part of the prograding sequence. This suggests deposition on the upper part of the paleocontinental slope. However, the loading history (Solheim et al., this volume) of the sediments and the biostratigraphic record indicate that deposition of massive diamictite at both sites was discontinuous, but both glacial retreat (except for Units III at Sites 739 and 742) and advance facies are unrepresented in the recovered intervals.

Another explanation of massive diamicts is that they formed in a distal to proximal glaciomarine environment by a combination of ice rafting and suspension settling (Eyles et al., 1985). In such cases they have a blanket geometry, thinning over highs, and tend to occur in shallow water and contain biogenic material. Although fossils do occur in the massive diamicts of Prydz Bay, they are volumetrically unimportant. Furthermore the paleontological data suggest that most of the fossils in both massive and stratified diamictites were deposited in place, rather than reworked by ice readvances. This factor, together with the geometry of the sequences (especially the prograding wedges) leads us to reject the distal glaciomarine setting of the diamicts.

Massive diamict can alternatively be interpreted as lodgement or basal meltout till. Basal till is characterized by a strong preferred clast orientation (Lawson, 1981; Dowdeswell et al., 1985; Dowdeswell and Sharp, 1986). It typically occurs in thin beds, contains scattered sand and gravel stringers and shear structures, and if marine organisms are present they are likely to have been reworked and generally broken. None of these features seem to be present at the Prydz Bay sites, except that at three levels at Site 742 (at 24, 143, and 197 mbsf; Fig. 16) a significant preferred orientation is evident. For the 24 - and 143-m samples, which were taken from Units II and III respectively, from within the flat-lying sequence, deposition as lodgement till is suspected. The lower unit in the prograding sequence may have been acquired when ice overrode it. Recovery was inadequate to observe bedding features and so precludes a certain assessment of the origin of the diamict but, as described by Solheim et al. (this volume), ice has loaded the shelf on several occasions.

Massive diamicts can also be interpreted as debris-flow deposits. These would comprise thin beds (mainly less than several meters thick), and have sharp loaded and erosional lower contacts. They may also show coarse-tail grading and contorted bedding and contain intraclasts of ripped-up material. Clast orientation fabric can range from preferred, as in lodgement till, to random (e.g., Anderson, 1983; Domack and Lawson, 1985; Lawson, 1981). These criteria hold only for a few beds of several decimeters thickness in the complex Subunits IIIA of Site 742 (Fig. 23) and IIIC of Site 739 (Fig. 24). However, although the bulk of the massive diamict does not have positive evidence of debris flow, a certain amount of resedimentation cannot be ruled out in the prograding units, particularly as some stratified diamictites clearly are slumped. Seismic data from Units III and IV at Site 739, in fact, do show signs of slumping or debris flow.

Weakly to well-stratified diamictites (Dw, Ds) (Subunits IIIA and IIIC of Site 739 and Subunits IIIA and IIIC at Site 742; Figs. 24 and 23 , respectively) probably demonstrate the transition from waterlain to proximal glaciomarine sediment. In general, away from the grounding line, the influence of current reworking and sorting is likely to become increasingly important. Deposition of material directly from the floating glacier or from its bergs becomes more sporadic, and biogenic material (notably diatoms and small shelly fossils) can accumulate, often without disturbance.

Neither at Site 739 nor at Site $\mathbf{7 4 2}$ have sorted sediments indicating currents been observed, except for a few gravel layers (Pl. 1, Fig. 5). Nevertheless, some segregation into more muddy layers with fewer stones and sandier layers with more stones is in evidence. This may reflect changes in the direct input of the glacial component and perhaps fluctuations of the grounding line and the seaward limit of the ice sheet.

Alternatively, the diffuse stratification could have formed by segregation of coarser and finer material within mudflows. Variable amounts of the mud component may have been derived from suspension and carried into the envisaged setting by meltwater emerging at the base of the ice mass at the grounding line. Today, however, the amount of meltwater associated with Antarctic glaciers, even those like the Lambert Glacier (Allison, 1979) that are sliding on their beds, is limited, and probably little reaches open continental shelf areas. Nor is there much direct evidence of large quantities of meltwater (e.g., sorted sand and gravel) in the Prydz Bay cores. Even so, in the absence of any other dominant sediment source, mud would have been derived from meltwater or from direct melting out of debris-rich ice at the grounding line. The stratification becomes more pronounced seaward, as the degree of reworking becomes more intense. A good dropstone structure in Core 119-739C-34R indicates the release of gravel and finer material from floating ice as an active process. Other dropstone structures may not have survived slumping or bioturbation.

Little can be said about the diamictons forming the upper part of the flat-lying sequence at all shelf sites because they are so disturbed by drilling and so poorly recovered. However, the diatom content of up to $35 \%$ suggests deposition in part as more distal glaciomarine sediment or the incorporation of diatomaceous sediment, such as that forming on the shelf today, by grounded ice or ice scouring. The poor recovery was partly due to the presence of boulders in the diamicton. The boulders are inferred to belong to a more proximal glacial deposit, such as a lodgement or melt-out till, which is in agreement with the overconsolidation of the layer. It is also possible that the sediment acted as a deforming layer beneath the ice as the glacier advanced across the shelf, in the manner suggested by Alley et al. (1989) for Ice Stream B, Ross Ice Shelf.

Diatomaceous mud and mudstone (DM) and massive sandy mudstone with some diatoms (SMm) (Unit III, Site 739, and Unit III, Site 742) are representative of distal glaciomarine sediments in which the greater proportion of planktonic microorganisms suggests increased surface water productivity as the glaciers receded or decreased dilution by terrigenous matter. The terrigenous component is still dominant and its muddy character suggests derivations from meltwater and deposition below wave base, with the coarser sand fraction representing an icerafted component.

Diatom ooze, present in the surface layer at all sites except Site 739, and diatomite (DO) in Subunit IIIB, Site 742, suggest periods of enhanced biological productivity on the continental shelf and in upper slope waters. Today, the diatom ooze is associated with low rates of terrigenous input, but there is still a significant component of ice-rafted, and possibly meltwater-derived, material. Therefore, glaciers still reached the coast where these minor facies were deposited.

Stratified mudstone (Ms, minor Mw), ranging from sandrich to gravel-rich, is represented mainly by Subunit VIA near the base of Site 742 (Fig. 25 and in more detail, Fig. 26). The paleobathymetric setting suggested by the seismic data and the lack of diatoms also suggests a lacustrine setting, but a protected glaciomarine environment such as a fjord is also likely. Part of the mud component is probably derived indirectly from meltwater (e.g., as turbidity currents). The coarser fraction is ice rafted, a view confirmed by the presence of scattered dropstone structures, and a position close to the ice margin is inferred.

Well-sorted sandstone (S) occurs only near the base of Site 742 , where it is intermixed with diamictite and mudstone as a result of soft-sediment deformation. In the overall context of the 


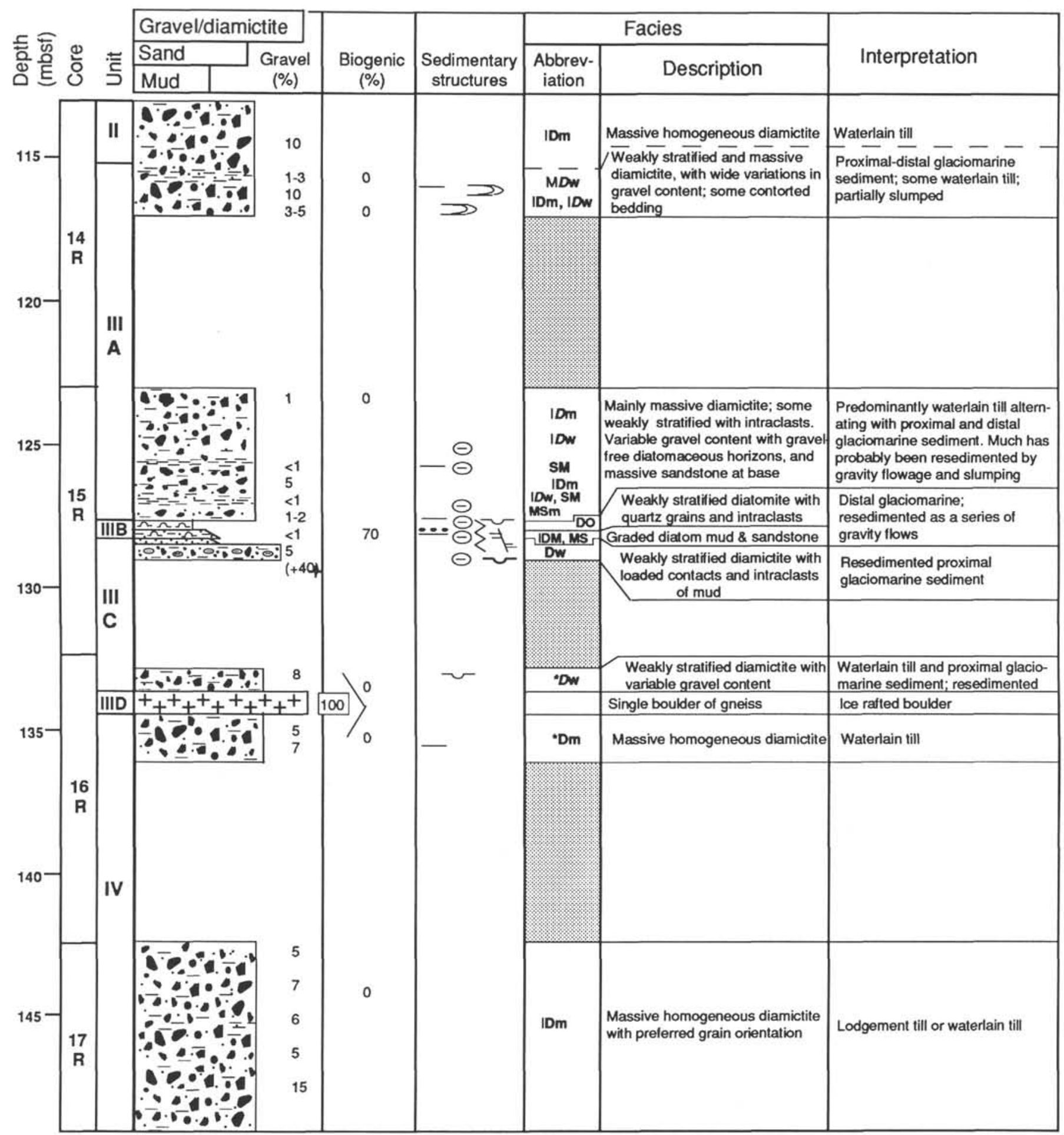

Figure 23. Detailed stratigraphy, sedimentology, and interpretation of the mixed facies Unit III, Site 742. Key as for Figure 21.

Prydz Bay succession, the primary origin of this sand may be fluvial. Alternatively, the sand may be the product of transport in suspension by strong currents; such sands have been found in the present-day outer shelf areas of Antarctica (Anderson and Smith, 1989). However, all criteria that may have helped to define the origin have been destroyed.

Minor laminated beds $(R)$ occur within the stratified diamictite of Subunit IIIC, Site 739. They appear to be rhythmites, like many such rhythmites in glaciomarine settings (e.g., Mackiewicz et al., 1984), the pulses of sediment probably originating from the limited mud-laden subglacial meltwaters, or disaggregation of debris-laden basal ice.

None of these sediments provides much insight into water depth, although future work on the foraminifers and rare invertebrate faunas may help. There is no indication of the effect of waves, and it is inferred that deposition occurred below wave base for sediment beyond the glacier snout, that is, in the outer proximal to distal glaciomarine environment. 


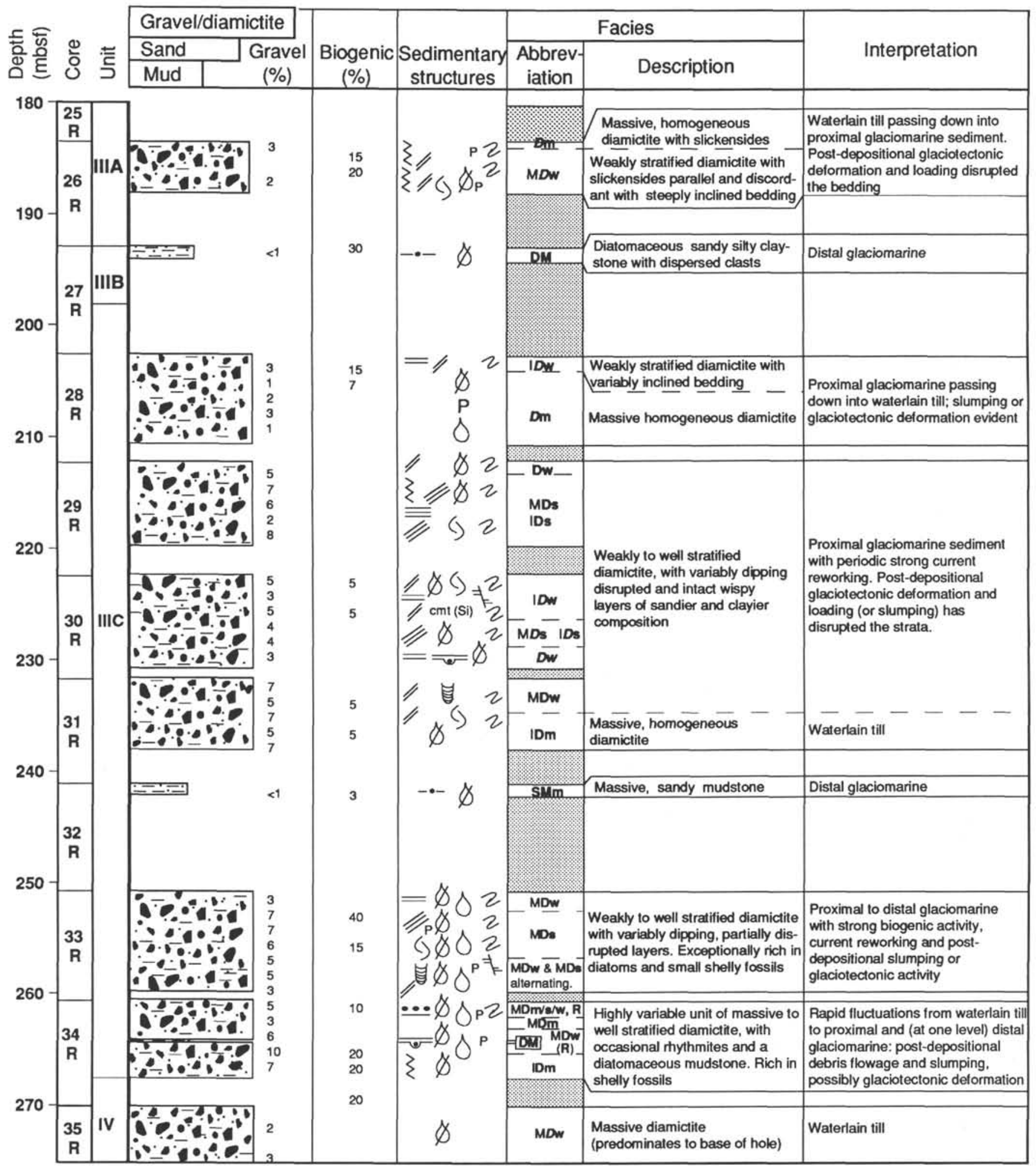

Figure 24. Detailed stratigraphy, sedimentology, and interpretation of the mixed facies Unit III, Site 739. Key as for Figure 21.

\section{Reworking of Sediments}

\section{Bioturbation}

There is only limited evidence of bioturbation at the Prydz Bay sites. Only weakly and well-stratified diamictites have been affected, and bioturbation takes the form either of diffuse mottling or of burrows. The latter are diffusely or sharply defined and tend to be characterized by more clay-rich material than the host sediment. Some burrow fills at Site 739 have been replaced by pyrite. 


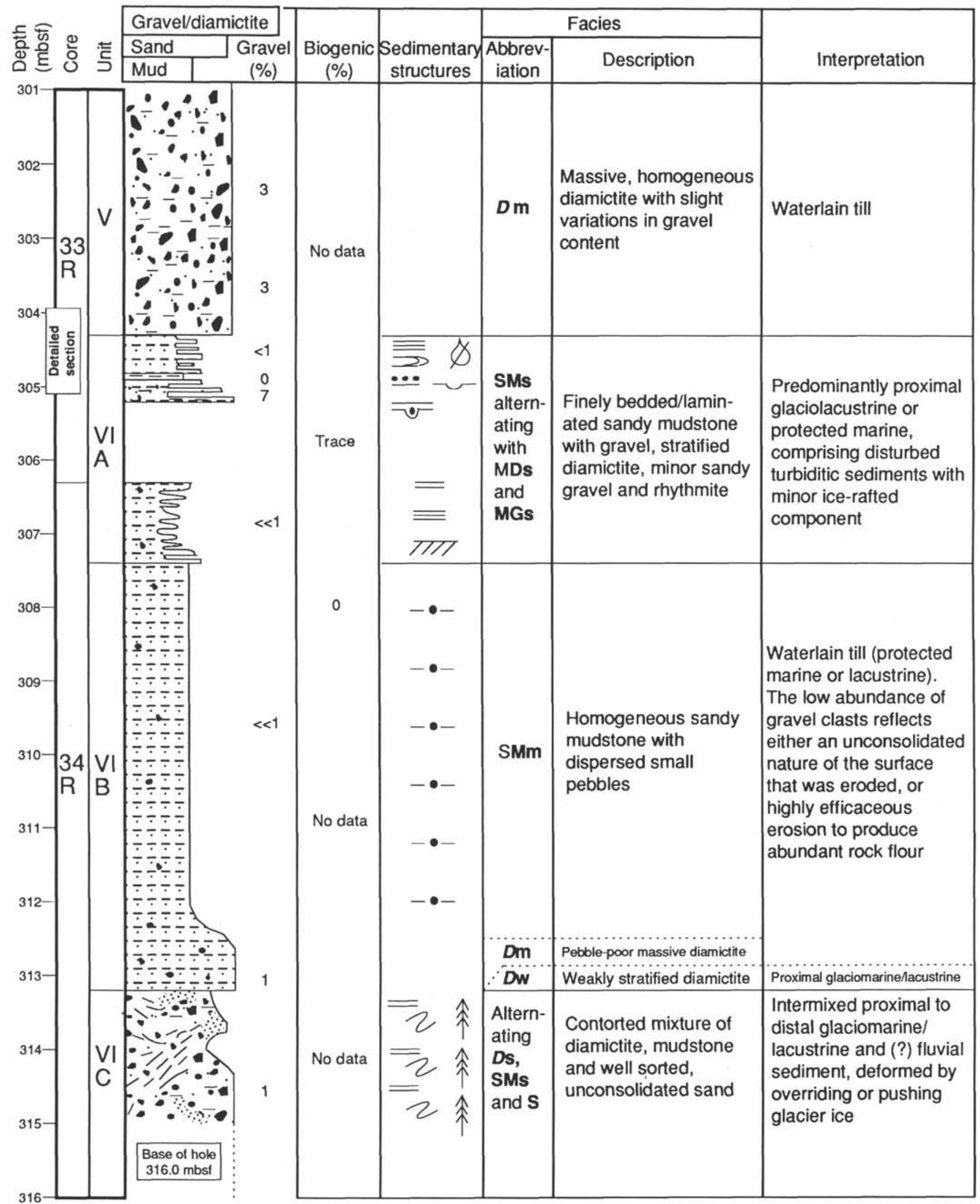

Figure 25. Stratigraphy, sedimentology, and interpretation of the lowermost $15 \mathrm{~m}$ of Site 742 (Unit VI), indicating predominantly a poorly sorted mudstone unit and strong deformation in basal diamictite. Key as for Figure 21. 


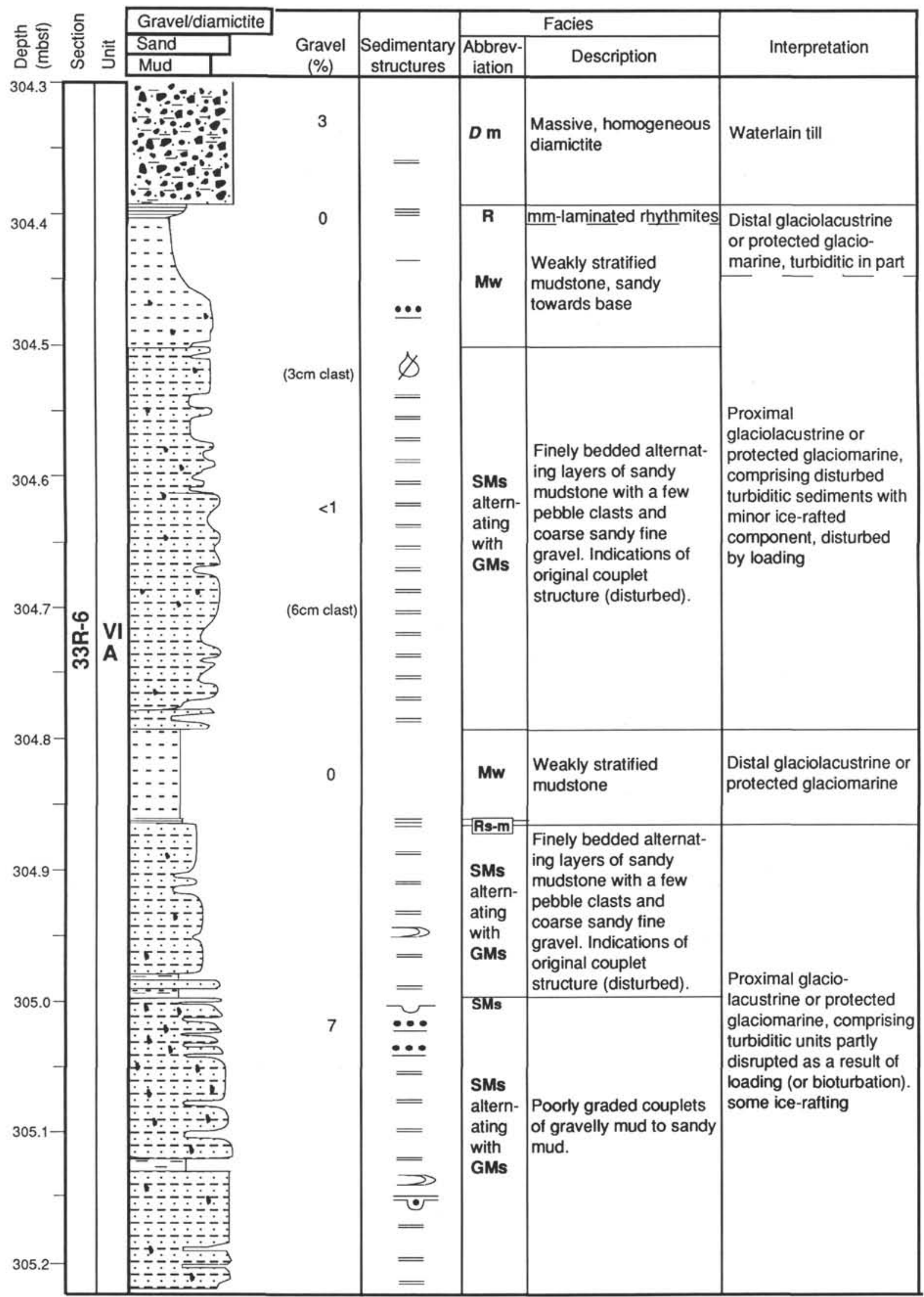

Figure 26. Detailed sedimentological log with interpretation of part of mudstone Subunit VIA at Site 742 (see Fig. 25 for position in section). Key as for Figure 21. 


\section{Slumping}

There is no positive evidence that most of the recovered sediments, notably the massive diamictites, have been remobilized following deposition. However, downslope readjustment by settling, especially in the prograding units, may well have taken place. In contrast, some stratified diamictite intervals do show signs of slumping, especially in the prograding Unit III, Site 739 (Pl. 4, Fig. 1), and Unit III, Site 742. Most commonly, downslope slumping of unconsolidated material is indicated by highangle bedding with sporadic similar to isoclinal fold noses in stratified sediments.

\section{Gravity Flow}

Remobilization as subaqueous sediment gravity flows apparently was only an isolated process. A few massive diamictite beds up to several decimeters thick, with sharp tops, coarse-tail grading, and intraclasts are suggestive of gravity flow (Pl. 4, Fig. 2). Some beds of diatomite and diatomaceous mudstone, which have sharp boundaries, could have been emplaced as turbidity currents, but the evidence is unclear.

\section{Glaciotectonic Deformation}

Glaciotectonic deformation normally takes the form of overconsolidation of certain horizons in the flat-lying and upper part of the prograding sequences. Overconsolidation is accompanied by the development of slickensided shear fractures at a moderate angle to the flat-lying beds and some are parallel to favorably orientated, possibly previously slumped, inclined beds. Near-vertical normal faults are also in evidence. These features affect all facies at the affected horizons.

A more extreme form of glaciotectonic deformation is suggested by the highly deformed and intermixed glacial and nonglacial sediments in Unit VI at the base of Site 742 (Pl. 4, Fig. 3). Alone, these deformation structures could have been explained as a result of slumping, but the seismic-reflection profile indicates that this is merely the top of a highly deformed unit $100 \mathrm{~m}$ thick. Whether this is the result of ice push of unconsolidated sediments on a huge scale or the effect of overriding ice cannot be established.

\section{Significance of Biogenic Sedimentation}

\section{Siliceous Microflora}

Opaline material identified in smear slides comprises the skeletal remains of diatoms, radiolarians, silicoflagellates, and sponge spicules. Diatoms are by far the most abundant siliceous microfossils in Prydz Bay sediments, and at some levels they account for several tens of percent of the total sediment by volume. Most diatoms are broken, but there is much evidence that they are not entirely reworked (J. Barron, pers. comm., 1989). The opal content may serve as an indicator for the marine influence on the shelf sedimentation.

The importance of diatom ooze in the sediments of this part of the Southern Ocean was recognized as early as 1874 by the Challenger expedition (Murray and Renard, 1891). Udinsev (1975) and Leg 119 scientists noted that the most recent sediments are diatomaceous. Drilling in Prydz Bay yielded up to several meters of muddy diatom ooze at the surface, demonstrating that diatom-rich sediments accumulate in sufficiently sheltered areas. Thus the phytoplankton are characteristic of cold waters (measured during drilling at around $0^{\circ}$ to $+2^{\circ} \mathrm{C}$ ) or typical Antarctic reduced glacial conditions (Fryxell, this volume). In other parts of Prydz Bay, notably close to the Amery Ice Shelf front, deposition of terrigenous mud is the dominant process today (Quilty, 1985). Elsewhere in Antarctica, diatomaceous mud and ooze comprise the most common surface sedi- ment in the shelf basins of the Ross Sea and George V Coast (Dunbar et al., 1985, 1989), the Bransfield Basin (Anderson et al., 1983) and the fjords of the western Antarctic Peninsula (Domack, 1988).

The inner shelf Site 742 (Fig. 4) shows only traces of diatoms upcore until the upper Pliocene-Quaternary diamicton/ite part of the sequence is reached. Whether this reflects direct association with proximal glaciomarine conditions or reworking by ice is unclear. However, the lack of diatomaceous material in the bulk of the core reflects close proximity to the ice margin, and floating ice may have overlain the site, cutting out the light and preventing life forms from surviving. Furthermore, the source of the diamict did not include diatomaceous sediment to any significant degree. This is unexpected, as at least some of the sedimentation took place near the paleoshelf break, and the few diatoms and shell fragments indicate that there was some marine influence in this area.

In contrast, Site 739 (Fig. 5) has a much richer proportion of diatoms, and all except the lowest lithologic Unit $\mathrm{V}$ contain $5 \%-20 \%$, and sporadically $30 \%$, diatoms. The observation of diatom ooze with a diverse diatom flora enclosed within cavities in shells (Pl. 3), which in turn are enclosed in homogeneous diamictite, indicates that some diatomaceous sediment was incorporated in and transported by ice or mixed during local debris-flow events. However, the high content of diatoms in Site 739 Units III and IV, which belong to the higher part of the upper prograding sequence and thus were deposited on the upper continental slope, might indicate sedimentation of diatoms in place. This implies that ecological conditions for diatom production were more favorable during deposition of these units than compared with those parts of the prograding unit represented by Site 742 , Unit V at Site 739 and Units II and III at Site 743. Therefore, Site 739 represents a somewhat more distal glaciogenic facies in comparison with that at Site 742 , as well as the presence of later-deposited Oligocene sediments that are not represented at the inner site.

The topmost sample from Site 743 probably represents the present-day conditions on the slope, as it is rich in diatoms. However, the deeper parts of the site, with the soft and normally consolidated diamicton, do not contain significant amounts of diatoms. This suggests that the ice conditions were too severe at the time of deposition to support diatoms. Alternatively, diatomaceous diamictons may have been lost during drilling.

The proportion of diatoms is linked to the type of facies, although in no systematic manner (cf. Fig. 24). The massive diamict has the fewest diatoms, in accordance with its probable deposition close to the grounding line. Stratified diamictites (and muddy sandy sediments) tend to have the most, as the marine influence is more pronounced. Diatoms often live beneath and within sea ice, but the absence of light probably precludes them from living beneath a thick ice shelf. However, some diatoms may have drifted into unfavorable life positions, such as under floating glacier ice, carried by weak currents.

In summary, the percentage of diatoms in the Prydz Bay sediments can give an approximate idea of the proximity of ice. Where diatoms are absent from diamict, we suspect that an ice shelf lay over the site. The limited degree of reworking evident in the diatom assemblages, with little mixing of species of different ages (Baldauf and Barron, this volume) suggests that they have not been transported by vigorous processes such as by moving ice, but in general were deposited in situ.

\section{Biogenic Calcium Carbonate}

In contrast to diatoms, foraminifers and calcareous nannofossils occur only in trace amounts. Foraminifers are totally absent at Site 742, and at Site 739 they are restricted to Cores 119$739-1 R$ to $-5 R$. Calcareous nannofossils are also rare but more 
common than foraminifers. At Site 742 , nannofossils are recorded in samples from Cores 119-742-11R and $-13 \mathrm{R}$, and at Site 739 from Cores 119-739-2H, $-2 \mathrm{X},-8 \mathrm{R},-12 \mathrm{R},-13 \mathrm{R},-18 \mathrm{R}$, 26R-30R, 33R-42R, 44R, and 46R (Barron, Larsen, et al., 1989). The nannofossils also do not show a mixing of species of different ages, and therefore are not reworked from older sediments. It is probable that nannofossils in the past may have lived close to the ice front because Paleogene and possibly also Neogene water temperatures were warmer than those of today. The lower temperature limit for coccolith survival today is $1^{\circ}-2^{\circ} \mathrm{C}$; above $2^{\circ} \mathrm{C}$, blooms may occur in summer (Wei, pers. comm., 1988). From the ice front the nannofossils may have drifted beneath the ice and been sedimented there. This hypothesis is supported by the generally higher carbonate and nannofossil content at Site 739 compared with that of Site 742 , which was closer to the grounding line of the ice shelf complex.

The enhanced carbonate concentrations in Units III and IV of Site 739 correlate with a maximum in opaline material. These units, therefore, represent sediments with a higher marine influence than the rest of the site. The maximum in calcium carbonate concentration may correlate with that of Unit IV at Site 742. These carbonate concentrations are also thought to result from enhanced productivity near the ice front. Diatoms are totally missing in this interval at Site 742 as in most of the sequence, probably because they were unable to drift the long distance from the ice front to the site.

An alternative source for the carbonate in the Prydz Bay sites could be the transport of detrital material. The sandstones of the Amery Formation in the hinterland of Prydz Bay in part are calcareous, and farther inland some marble occurs (Trail and McLeod, 1969). Both could represent source areas for calcareous material. However, apart from rare calcareous sandstones, no detrital carbonate clasts were encountered at the Prydz Bay sites. Furthermore, detrital carbonate grains were not detected in smear slides. Therefore, the carbonate content is most probably is marine derived. The small nannofossil and foraminifer component at Sites 739 and 742 provides some support for this hypothesis.

\section{Macrofauna}

Small shelly fossils, especially scaphapods, also occur sporadically throughout Site 739 . As expected, they are most abundant in the most distal glaciomarine sediment, especially in Unit III (Fig. 24) where both broken and intact forms occur. At Site 742 very few macrofossils were observed, in keeping with the more proximal glacial conditions at this site. No paleoenvironmental studies have yet been made on the macrofauna, but $\mathrm{Sr}$ isotope measurements were made on shells from Site 739 (Thierstein et al., this volume), as reported previously.

\section{Significance of Organic Carbon and Sulfur Content}

The organic carbon content of marine sediments is controlled by the primary carbon flux to the seafloor, the oxygen content of the bottom water, the intensity of the degradation of organic matter, and the diluting effect of other sediment components. In Prydz Bay, dilution by terrigenous components is especially significant. Detritus of land plants and remains of marine organic matter are both possible sources of the organic matter found in the Prydz Bay sediments. The content of organic carbon is $0.4 \%-2.0 \%$ in the diamicts at Sites 742 (Fig. 4), 739 (Fig. $5)$, and 743; this is comparable with values obtained from other high-latitude glaciated shelves, for example, $1 \%-2 \%$ for the Barents Shelf (Bjфrlykke et al., 1978; Elverh $\phi i$ et al., 1989).

The diatom ooze and diatomaceous mud of the upper few meters of Sites 740,741 , and 742 contains $1.4 \%, 0.2 \%$, and $0.3 \%$ organic carbon, respectively. These figures are similar to the amounts found in diatom-rich deposits at the Kerguelen
Plateau Sites 736 and 744 (Barron, Larsen, et al., 1989; Ehrmann, this volume; Cranston, this volume) and the Ross Sea Shelf (Dunbar et al., 1985). This suggests that the marine "diatom ooze" component of the diamict also is unlikely to contain more than $1 \%$ organic carbon, a value which is further reduced by the addition of terrigenous components. No correlation between the content of organic matter and the amount of opal (diatoms) is observed in the diatom-bearing intervals within the diamicts. Indeed, the $\mathrm{C}_{\mathrm{org}}$ content is as high, but variable, as in the various barren intervals in the diamict sequence. This pattern is not consistent with a pelagic origin for the organic matter. Correlation of organic matter with the clay content or with grain-size distribution, which would suggest transport of organic matter in association with finer grains in suspension, has also not been observed.

Rock Eval analysis on samples from Sites 742 and 743 indicated that most of the organic matter is type III kerogen (i.e., a coal/terrigenous woodlike substance) and that significant reworking of organic matter of various compositions and sources occurred (Barron, Larsen, et al., 1989). Also, the extremely slow rate of sulfate reduction shown by the presence of sulfate in the pore water points to very refractory organic matter. Thus it seems likely that a significant proportion of the organic matter is old detritic material recycled from carbonaceous sediments. Such sediments of Cretaceous age have been observed beneath the diamictites at Site 741 (Barron, Larsen, et al., 1989), and in the Permian Amery Formation in the Beaver Lake area of the Prince Charles Mountains (Trail and McLeod, 1969). Bardin (1982), for example, found $2 \%-4 \%$ organic carbon in tills overlying the Permian sediments.

The content of sulfur is low in most of the upper Miocene interval at Sites 739 and 742, whereas the organic carbon content is high (Figs. 4 and 5). Furthermore, no correlation between organic carbon and sulfur is evident in the rest of the sequence. Sulfate reduction by the organic matter in the diamicts as the cause for the sulfur content is not evident. We therefore suggest that a significant part of the sulfur is derived from sulfide minerals, mainly from the basement areas.

At Site 742 an inverse correlation between magnetic susceptibility, related to the content of magnetite, and organic carbon was noted by $\mathrm{H}$. Sakai (pers. comm., 1988). The magnetite and sulfides must have been eroded mainly from basement areas, whereas the organic carbon is an indication of erosion of sedimentary rocks. This inverse correlation possibly mirrors the changing proportions of a basement vs. of a carbonaceous sedimentary source for the diamicts.

The clear maximum of organic carbon combined with the low content of sulfur that characterizes the Oligocene Unit IV at Site 742 and the upper Miocene lower part of Unit II at Site 739 , accordingly might indicate a two- to four-fold increase of erosion of the preglacial sediments relative to basement rocks. This suggests enhanced ice stream erosion and downcutting in the Lambert Graben, in contrast to erosion of the basement areas bordering the graben and to the east at that time.

\section{Significance of Clay Minerals}

Chlorite and illite are especially common in marine sediments of the high latitudes (Biscaye, 1965; Griffin et al., 1968). These clay minerals are mostly detrital, as they are the products of physical weathering on land or of glacial scouring, particularly of crystalline or metamorphic rocks, such as those that are widespread in East Antarctica (e.g., Ravich et al., 1984). Chlorite is a characteristic mineral from low-grade metamorphic and basic source rocks, whereas illites tend to be derived from more acidic rocks (Griffin et al., 1968). The hinterland of Prydz Bay provides large quantities of appropriate source rocks supplying both illites and chlorites. This area is composed mainly of 
migmatites and biotite-quartz-feldspar gneiss and smaller areas of charnockite. Farther inland, quartzites, quartz-mica schists, and some ferruginous schists occur (Trail and McLeod, 1969; Craddock, 1982; Ravich and Fedorov, 1982). Bardin et al. (1979) and Bardin (1982) found soils and tills in the Prince Charles Mountains containing largely illite, chlorite, and some smectite and vermiculite in the clay fraction.

Higher concentrations of kaolinite are normally restricted to between temperate and tropical regions. There, long-continued and intense chemical weathering, especially of granitic source rocks, and soil formation occur on land. Kaolinite cannot form under glacial conditions. Therefore, high kaolinite concentrations were unexpected in the Prydz Bay glacial sediments that appeared to have been formed immediately seaward of the grounding line of a large ice shelf complex. We suggest that much of the kaolinite is a recycled product, derived as a result of erosion of old kaolinite-bearing sedimentary rocks or soils. Equivalent rocks to the Permian Amery Formation, which may have occupied the Lambert Graben, may have been the source of the kaolinite. The Amery Formation crops out at Beaver Lake, just west of the main stream of the Lambert Glacier, close to the present-day coastline, although its extension beneath the ice is not known. The unit is at least $500 \mathrm{~m}$ thick and is composed of feldspathic sandstones, calcareous in part, made up of angular grains of quartz, potash feldspar, and minor plagioclase in a kaolinitic matrix (Trail and McLeod, 1969). Bardin (1982) found kaolinite as a component in the clay fraction of tills near Beaver Lake as well as in tills at Mount Rubin, $300 \mathrm{~km}$ farther inland.

The significance of the smectite is less clear (Chamley, 1989). Smectite has been detected in Antarctic tills (Bardin et al., 1979; Bardin, 1982) and soils (Campbell and Claridge, 1987; Claridge and Campbell, 1989). It is therefore possible that the smectite was recycled from unknown preglacial sediments and soils. Some of the smectite might be degraded illite/biotite leached during transport (Foged, pers. comm., 1987). Smectite also might be derived as a result of submarine chemical alteration of volcanic material (Biscaye, 1965). It then could represent the marine influence on the sedimentation.

Clays containing a variable amount in excess of $20 \%$ smectite are widespread on the continental rise off the Weddell Sea (Lisitzin, 1972; Grobe, 1986b). The origin of the smectite is not known, but according to Grobe (1986b) the variations in the rate of transport of the tiny smectite grains, as for all clay-sized material, by currents are important for the distribution of this mineral. Smectite is not, as far as is known, a significant component of surface sediments or of suspended sediments on and off Prydz Bay today (Udinstev, 1975).

The high kaolinite and enhanced smectite content in the deepest parts of Sites 742 and 739 (Figs. 6 and 7) suggests that the earliest glaciers eroded large quantities of soil and loose weathering products derived from both basement rocks and Permian and younger sedimentary strata. This younger material would have been easily eroded and transported into Prydz Bay. Later, when all of the loose, unconsolidated detritus had been removed, the glacier began to erode unweathered rocks, especially those forming the basement, and therefore only minor amounts of kaolinite were transported. In contrast, the glacially derived clay minerals illite and chlorite increased in concentration. The major shift in clay mineral composition occurs at about 280 mbsf at Site 739 and 140 mbsf at Site 742 .

Considering the geological and glaciological setting of these two sites, it was expected that the distinct shifts in kaolinite concentrations would be correlatable. Dating problems result in only rough age estimates. An early Oligocene age is probable for the shift in Site 739, because it occurs within the prograding sequence. At Site 742, this shift falls within the undated, unconformity-bounded interval of lithologic Unit IV, which forms the base of the flat-lying sequence at that site. Some meters above Unit IV, diatoms indicate a late early to early late Pliocene age. A Pliocene age for the change in glacial erosional style seems to be too young, by comparison with Site 739 , as the loose weathering products and soils containing larger quantities of kaolinite should by then have been eroded and transported away. It is possible, therefore, that Unit IV at Site $\mathbf{7 4 2}$ has an early Oligocene age and was deposited on the shelf at the same time as the prograding sediments in Unit IV at Site 739 or that it consists of glacially eroded and redeposited older diamictite.

The investigations of the clay mineralogy of Sites 738 and 744 on the southern Kerguelen Plateau (Ehrmann, this volume) reveal that kaolinite first appeared in significant amounts at about the same time as the first ice-rafted gravel and sand debris, in early Oligocene time. Kaolinite input also coincides with an increase of the glacially derived clay minerals illite and chlorite, and is thought to mark the onset of coastal glacierization in the East Antarctic. The high kaolinite content on the Kerguelen Plateau thus matches that of the oldest sediments at Sites 739 and 742 . The Prydz Bay glacial sediments may therefore not be older than early Oligocene because, if this pulse of kaolinite input on the Kerguelen Plateau is older, a matching record would be expected to occur there also.

\section{Grain-Size Distribution as an Indicator of Source}

The grain-size distribution plots (Figs. 2 and 3) reveal a broadly similar view of the nature of the source rocks. The Oligocene units are slightly finer grained than the units above the flat-lying regional unconformity, as shown by the slightly lower proportion of sand, lower percentage of gravel clasts, and smaller average clast size, with some exceptions. We suggest that this broadly reflects (1) an earlier phase of enhanced erosion of finegrained graben-fill sediments, along with weathered basement rocks, and (2) a later phase when unweathered basement rocks provided a higher proportion of material. By that time the sedimentary sequence in the trough was already deeply eroded, and down-cutting was becoming less efficacious.

\section{Source of Gravel Clasts}

The least ambiguous information concerning the source area for the diamicts comes from the petrography of the clasts enclosed in the sediment, as discussed in Barron, Larsen, et al. (1989) and Jenkins and Alibert (this volume). Most of the rocks are metamorphic of various grades, very similar to the migmatites, biotite-garnet-feldspar gneisses, and charnockites known from the hinterland of Prydz Bay (Trail and McLeod, 1969; Ravich and Fedorov, 1982). As mentioned in the stratigraphy section, a few clasts of sandstone and fragments of coal also occur. However, the probably poorly lithified nature of the graben sediment-fill means that most sedimentary clasts were disaggregated during glacial transport.

The character of bedrock weathering prior to glacial erosion is also indicated by weathering rinds on the gravel clasts. A small fraction of basement and sedimentary clasts have well-developed weathering rinds, especially in the prograding part of the sequence. No systematic study of these clasts has yet been undertaken, however.

\section{Glacial Transport and Depositional Environment}

The sedimentary sequence is overwhelmingly of glacial character, and can be considered principally in terms of deposition close to and immediately seaward of the grounding line of an extended Lambert Glacier-Amery Ice Shelf system, probably close to the continental shelf edge. This is depicted in the generalized model (Fig. 20) and is discussed in detail in the section "Antarctic Glacial History" (Fig. 27), where a break in slope would promote decoupling of the glacier from its bed. Recon- 
struction of projected ice-flow lines over the continental shelf, based on present-day ice surface configuration and bathymetry, suggests that the ice that flowed over the Prydz Bay sites originated from the eastern margin of the Lambert trough or from much thinner, less channelized and therefore less dynamic ice flowing off Ingrid Christensen Land (Hambrey, this volume).

\section{Transport of Debris}

The fresh nature of both the gravel clasts and sand and siltsized grains in the flat-lying sequences points to a source area for the bulk of the sediment, that is dominated by physical weathering. The absence of significant angular supraglacial debris layers suggests that little material was derived from rock outcrops projecting above the ice. Probably little or no land was exposed; the bulk of the sediment was derived subglacially and modified by transport at the base of the sliding ice mass, where angular frost-shattered clasts were reworked into a broader range of shapes. The presence of a small proportion of weathered basement clasts in the lower part of the sequence implies erosion of previously weathered basement. The high kaolinite concentrations in the prograding parts of Sites 739 and 742 also suggest the transport of weathered sedimentary rocks to Prydz Bay.

Overall, there appears to have been little, if any, reworking by fluvial processes, or indications of eolian transport, except in Unit IV, Site 739, in which well-rounded quartz and feldspar grains occur. Clast composition indicates that the bulk of the detritus was derived from the nearby granite-gneiss basement, but finer fractions suggest a significant contribution from sedimentary sources and soils. No sedimentary rocks are known from the area east of the centerline on Lambert Glacier today, so the most likely origin of the sedimentary clasts is the graben itself, which probably achieved its present depth as a result of extreme glacial overdeepening.

The sequence is remarkable for its apparent uniformity, especially the homogeneity of the hundreds of meters of massive diamict. This can be explained only if the grounding line was in a relatively stable position or if interbedded lodgement tills and glaciomarine sediments were removed by subsequent glacier advances. The loading history of the sediment indeed suggests a more complex history of glacial advances and retreats than that indicated by the recovered facies (Solheim et al., this volume).

\section{Sedimentation during Phases of Continental Shelf Progradation}

In general, ice shelves, ice streams, and floating glacier tongues are characterized by rapid fluctuations in positions of their grounding lines and fronts. The causes of such fluctuations are not well established, but are probably related to ocean temperatures, sea-level changes, climatic changes, ice instability, or combinations of these factors. However, stable grounding line positions may arise if there is a sharp break in the submarine slope, such as at the shelf edge, beyond which grounding would require a vastly increased supply of ice. Ice-shelf stability would have been facilitated by the development of the Fram Bank and the Four Ladies Bank, through deposition during phases of advanced ice, and which subsequently could have served as pinning points for an expanded ice shelf.

This stable grounding line situation may have prevailed in Oligocene time, first at Site 742 , then progressively toward and beyond Site 739, as each massive diamictite unit accumulated. This view is supported by the nature of the seaward-dipping seismic reflectors that suggest progradation of the continental shelf through these sites. To provide the necessary sediment for progradation, deep erosion of the inner Lambert Graben would have occurred. As progradation proceeded, the ice may have flowed over a deformable bed of till as proposed by Alley et al.
(1989) for Ice Stream B, a tributary of the Ross Ice Shelf. Alternatively the ice may have begun to erode the top of the prograding sequence as suggested by the loading history (Solheim et al., this volume) or deposited a lodgement till. Although there is no unequivocal evidence that lodgement tills on the shelf are similar in age to the Oligocene prograding sequence, comparison of the clay mineral records suggests that this is a possibility. The Pliocene-Quaternary record illustrates both build up and occasional erosion or loading of lodgement till on the shelf (Sites 739-742) and continued progradation of the shelf (Site 743).

The bulk of the waterlain tills and glaciomarine sediments would have been deposited on the upper continental slope, creating the facies association hypothesized in Figure 20. The stratified diamictites of Unit III at Site 739 probably represent periods when the Lambert Glacier backed off the shelf edge slightly, but not enough to deprive the continental slope of its sediment source. Then the ice would have been subject to marked fluctuations, as characterized by the more varied nature of the sediments that range from waterlain till to distal glaciomarine. However, none of the sediments suggest ice as far back as it is at present, but such intervals may have been removed by glacial erosion.

In summary, although DSDP drilling on the Ross Sea continental shelf obtained a composite record of glacial sediments dating back to late Oligocene time (Hayes, Frakes et al., 1975), Prydz Bay Sites 739 to 743 have provided for the first time a record of the sequence on a transect from the inner shelf to the continental slope of Antarctica, in an area dominated for a prolonged period by a major glacier complex. The Prydz Bay situation may be typical of other parts of the Antarctic continental margin (e.g., western Antarctic Peninsula; Larter and Barker, 1989), and of some northern high-latitude continental margins, that have been under the influence of major ice drainage systems for millions of years.

\section{Sedimentation During Phases of Nonprogradation of the Continental Shelf}

As the ice backed off the shelf break, the landward inclination of the continental shelf would have starved the slope of sediment. The ice margin may have been much less stable than during progradation phases. The stratigraphic succession, which developed from waxing and waning ice in these circumstances, was a flat-lying one, comprising waterlain tills, glaciomarine sediments, and lodgement tills. Unit III (Pliocene) at Site $\mathbf{7 4 2}$ records such an association. These are periods, too, of loading and erosion, but although these processes are suspected in Sites 739 and 742 , the poor recovery precludes a realistic assessment of them.

\section{ANTARCTIC GLACIAL HISTORY}

\section{Nature of the Evidence}

The timing and initiation of the Antarctic ice sheet, and its subsequent development, have been the subject of considerable discussion since Leg 28 of the Deep Sea Drilling Project in the early 1970's yielded evidence that the Antarctic glacial record lasted much longer than that in the Northern Hemisphere (Hayes, Frakes, et al., 1975). Since then, as discussed in the Introduction, evidence for glaciation has come from three main sources, each with its drawbacks: (1) the direct glacial record from the continental shelf, although this suffers from gaps in the record, local tectonic influences and often inadequate age constraints; (2) the indirect $\delta^{18} \mathrm{O}$ record from deep-sea sediments, although this has been interpreted in different ways (e.g., Shackleton and Kennett, 1975; Shackleton, 1986; Matthews and Poore, 1980); and (3) the ice-rafting record from sub-Antarctic drill sites (e.g., the Kerguelen Plateau, this volume), although these sites may be 
A. Preglacial Eocene $(50 \mathrm{Ma})$

Site 740 Site 741
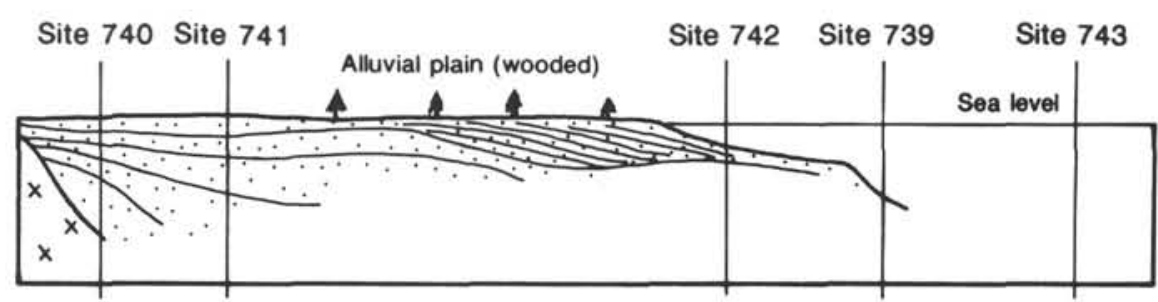

B. Onset of glaciation, Eocene-early Oligocene

(36-40 Ma)

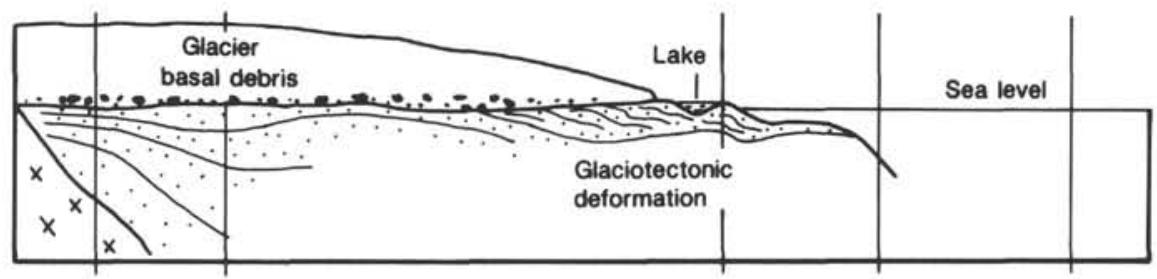

C. Early Oligocene; floating glacier ice at shelf break

(35 Ma)

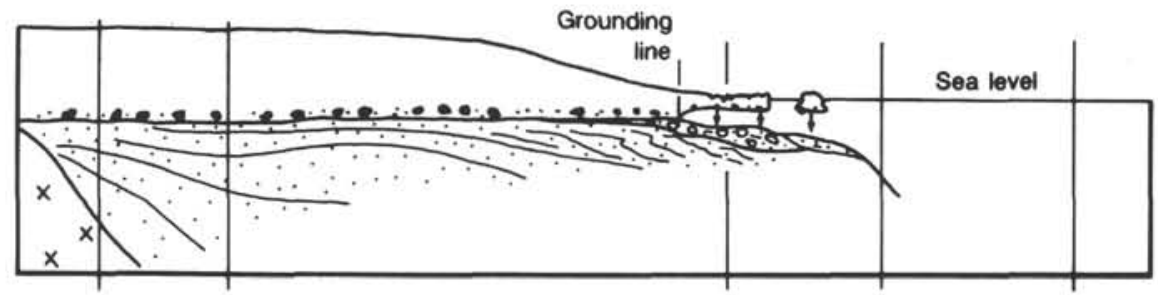

D. Early Oligocene; major shelf progradation, ice at shelf break

(30 Ma)

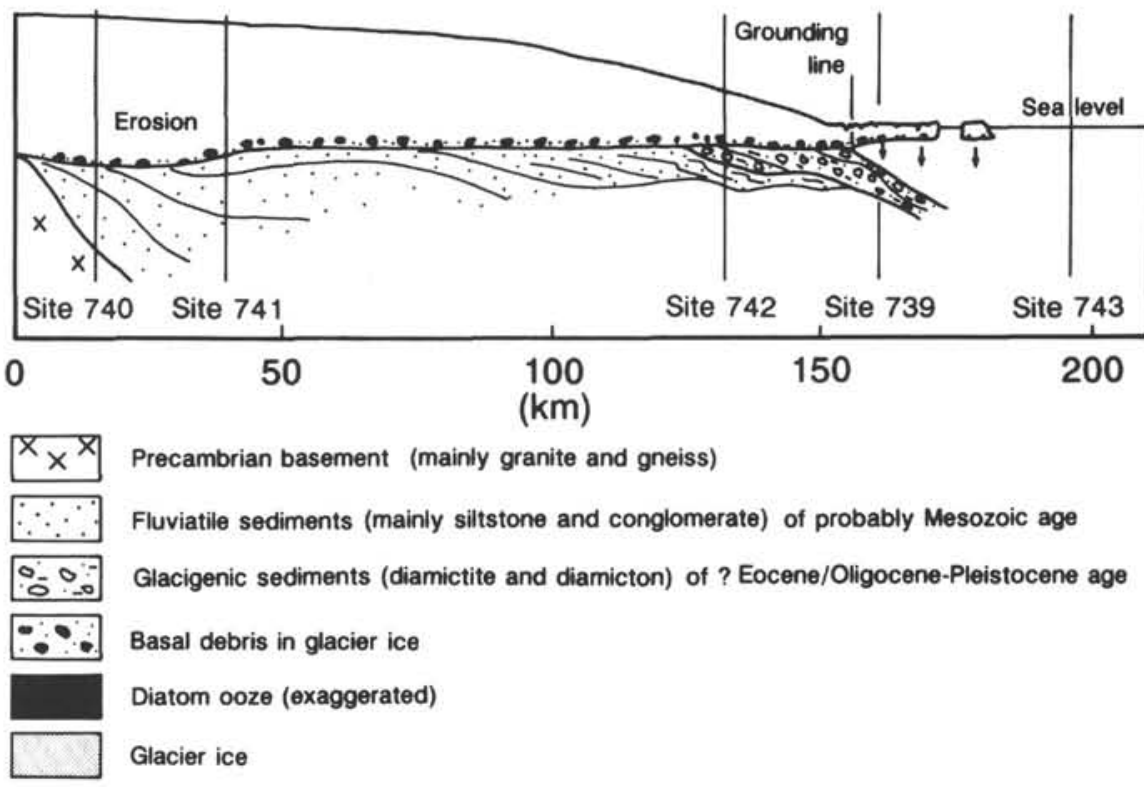

Figure 27. Summary of the main stages in the history of glaciation and development of the continental shelf, along a transect through the five Prydz Bay drill sites (see Fig. 1 for location). Ages according to the biostratigraphy of Barron, Larsen et al. (1989). Stages A-I discussed in the text. 
E. Late Oligocene-early Miocene (glacial maximum prior to Quaternary, $24 \mathrm{Ma}$ )

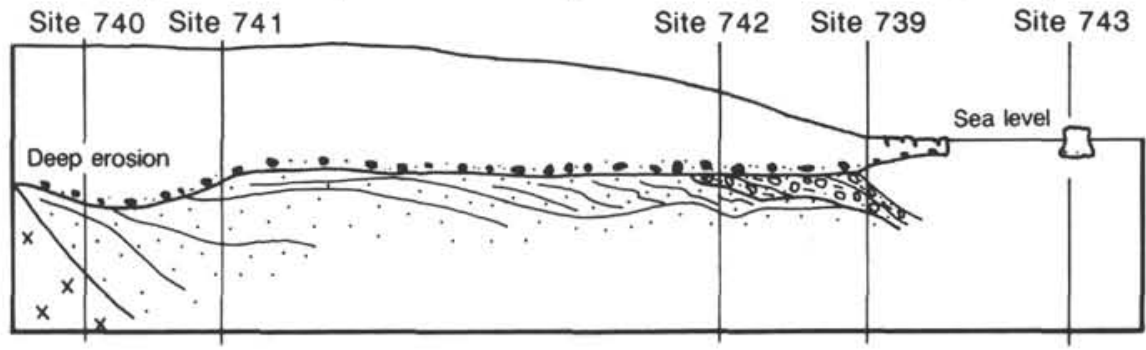

F. Late Miocene; retreat from shelf break (10 Ma)

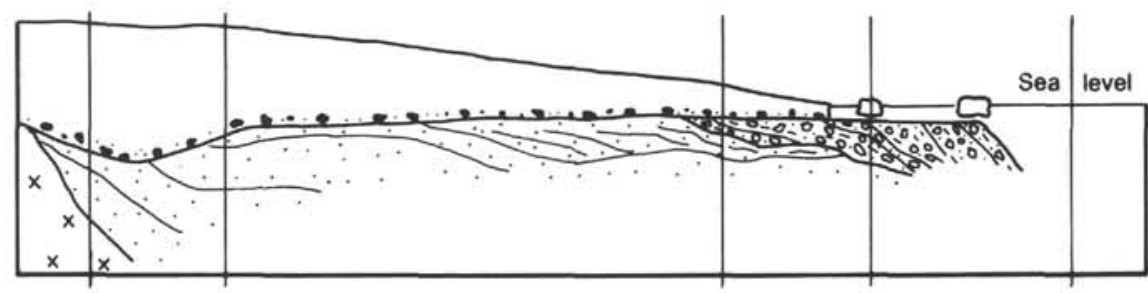

G. Early-late Pliocene transition; retreat phase (3-4 Ma)

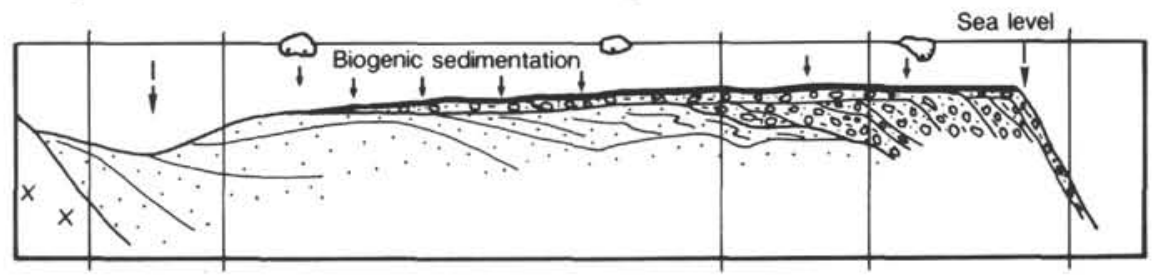

H. Late Pleistocene glacial maximum (20,000 yr. B.P.)

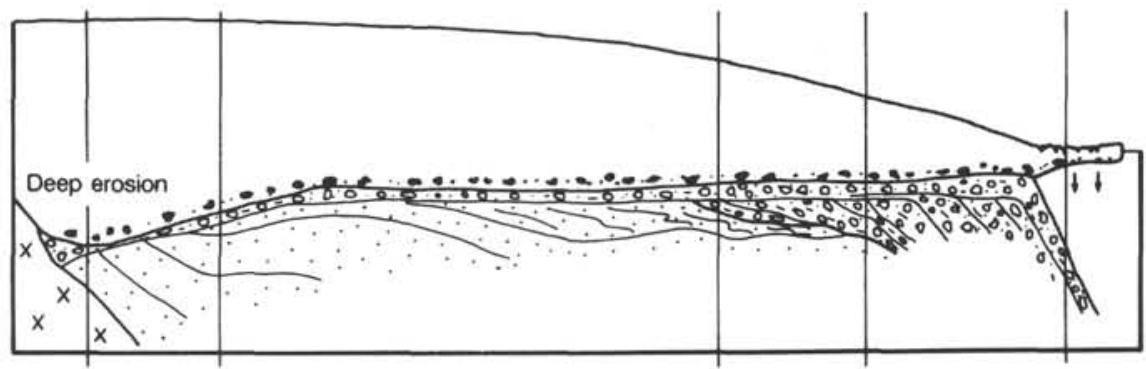

I. Holocene "interglacial" conditions (10,000 yr. B.P.-present)

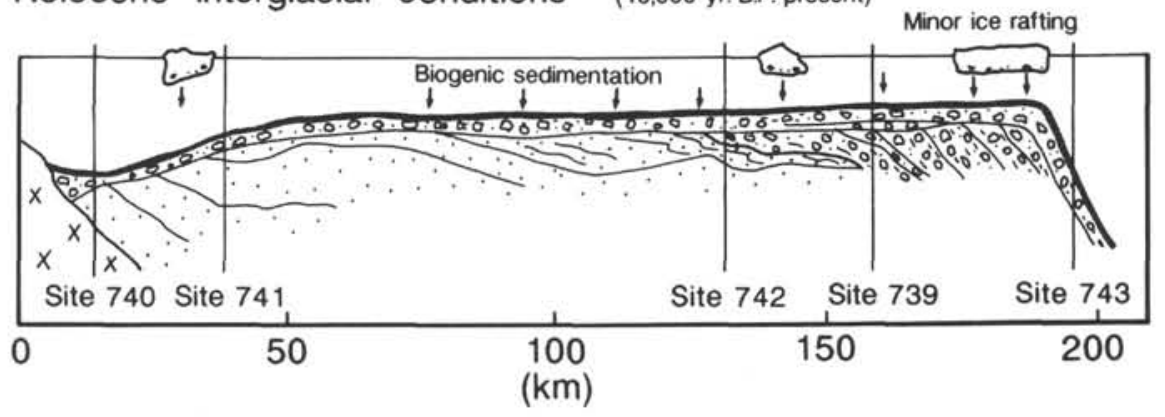

Figure 27 (continued). 
too distal from the continent to record the glacial history in full. Full interpretation of Antarctic glacial history, therefore, requires assessment of each of these lines of evidence.

Prydz Bay was selected as an area likely to yield one of the longest records of direct glacial influence in East Antarctica. Its location is such that it lies at the mouth of the Lambert GlacierAmery Ice Shelf catchment area that represents about a fifth of the drainage area of the East Antarctic Ice Sheet. Since the Lambert Graben, through which ice flow is concentrated, is a long-lived feature, the Prydz Bay continental shelf was expected to yield the earliest indications of ice at sea level as supplied by a large ice sheet, and not just by glaciers from high mountains.

\section{Prydz Bay Record}

The sparse and imprecise biostratigraphic record precludes detailed assessment of the glacial history of Prydz Bay, but a number of key phases may be inferred (Fig. 27). However, age constraints are still inadequate and biostratigraphic ages for Oligocene time are incompatible with strontium isotope dates from Site 739 (cf. Baldauf and Barron, this volume; Thierstein et al., this volume).

The base of the glacial sequence was not recovered, but the earliest diamictites at Site 742 indicate mixing with probable preglacial alluvial sediments. Such sediments were recovered at Site 741, the provisional age of which is Albian (Barron, Larsen et al., 1988). The preglacial sediments (fluviatile clastics with wood fragments) suggest that subaerial, cool- to warm-temperate conditions with extensive vegetation prevailed prior to encroachment by the ice (Turner and Padley, this volume). (Fig. 27A). Sometime in late Eocene or early Oligocene time, ice advanced across the alluvial plain to within close proximity of Site 742 , deforming the underlying sediment to a depth of $100 \mathrm{~m}$ (according to seismic data), and depositing a complex of waterlain tills and proglacial lacustrine or fjord sediments, in a setting partially constrained by a bathymetric high (Fig. 27B). Ice then reached the continental shelf break just landward of Site 742 (Fig. 27C) and began the phase of early Oligocene waterlain till deposition of the lower, gently inclined prograding sequence. By later early Oligocene time, grounded ice advanced across Site 742 and continued building up gently dipping, and then more steeply dipping prograding sequences at Site 739 (Fig. 27D). Simultaneously, deep erosion took place in the inner Lambert Graben, as a highly active, possibly temperate glacier complex flowed over poorly indurated sediments. Deep erosion of the coastal channels may also have begun at this time.

No late Oligocene to middle Miocene sediments were cored, because of an erosional unconformity created by expanded ice. However, sediments of this age are surmised as forming the prograding wedge seaward of Site 739 and probably represent continued advance of ice across the expanding shelf, thereby eroding it, during this period (Fig. 27E). Throughout the recovered record from this period there are no indications of glacial retreat facies, but seismic and logging data suggest that sands are present in the sequence and could represent such retreat phases.

The next phase of deposition is probably represented by continued erosion at Site 742 , as well as at Sites 740 and 741 , and deposition of horizontally bedded mixed glaciomarine facies of late Miocene age at Site 739. This suggests glacial retreat from the shelf break to a position between Sites 742 and 739 (Fig. 27F). A succession of advances and retreats across the shelf in late Miocene to Quaternary time is recorded, during which lodgement tills and glaciomarine sediments were deposited in alternation, and subjected to loading by overriding ice. The clearest evidence of retreat is in thin diatomaceous sediments of late early Pliocene age when, for a time, Site 742 (and probably the other sites) became ice-free. This retreat is also manifested nearby in the marine sediments of the nearby Vestfold Hills (Pickard et al., 1988; see next section). Glaciogenic sedimentation then was limited to iceberg rafting (Fig. 27G). Thereafter, ice reached the continental shelf break on an unknown number of occasions, and progradation of the shelf by grounding line sedimentation continued (Fig. 27H). Beneath the grounded ice sheet, lodgement tills were deposited. Finally, following the onset of interglacial conditions, characterized by predominantly diatomaceous sedimentation, the area ceased to be directly influenced by glaciers, although a minor amount of ice rafting and terrigenous mud deposition continued at these sites (Fig. 27I).

\section{Stratigraphic Record from Other Parts of East Antaretica}

Several drill cores have been obtained from other parts of Antarctica and together they provide a comprehensive, if incomplete and poorly constrained, record of sedimentation on the continental shelf since late Eocene or early Oligocene time (Fig. 28).

The 702-m CIROS-1 core in McMurdo Sound (Barrett et al., 1989a, 1989b; Barrett, 1989a; Hambrey et al., 1989a) has provided the most complete Oligocene to early Miocene record to date. The section is characterized by distinct upper and lower sequences, with a hiatus between. The lower half represents an early Oligocene phase dominated by the deposition of moderately deep water, poorly sorted sands under the influence of ice rafting, and occasional pulses of diamictite sedimentation, interpreted as waterlain till. This suggests tidewater glaciers, descending from the rising Transantarctic Mountains to the west, and calving of icebergs nearby.

This early Oligocene CIROS sequence is matched in Prydz Bay by the development of the prograding (late Eocene to) early Oligocene sequences of Sites 739 and 742 and suggests widespread ice reaching sea level in East Antarctica, lending support to the hypothesis of glaciation of ice sheet dimensions by this time. Both the Gamburtsev Subglacial Mountains and the Transantarctic Mountains may have been the initial foci for the development of the ice sheet.

The lower sequence in CIROS-1 ends with a marked shallowing event, evidence of fluviatile sedimentation, and a hiatus of about $4 \mathrm{Ma}$ at the early/late Oligocene boundary. Above this level, the late Oligocene to early Miocene upper sequence is characterized by a series of seven major glacial advances across the site, depositing complexes of lodgement and waterlain tills, and indicating continued ice rafting between. However, this all took place under a humid, temperate climate that was sufficiently amenable for the growth of a coastal beech forest with podocarps, proteas, and other shrubby angiosperms (Hill, 1989; Mildenhall, 1989). These major advances are not recorded in the Prydz Bay cores, but we have interpreted the missing late Oligocene to early Miocene record as representing a major advance of ice across the prograding shelf at this time (Hambrey et al., 1989b).

No post-early Miocene record was cored from CIROS-1, but neighboring MSSTS-1 and DSDP Sites 270, 272, and 273 in the Ross Sea indicate a major regional unconformity representing at least $10 \mathrm{Ma}$, probably created as a result of erosion by mid-Miocene to early Pliocene glaciers advancing across the shelf and responding in part to the development of the West Antarctic ice sheet (Savage and Ciesielski, 1983). In Prydz Bay this mid-Miocene to early Pliocene phase is represented also by an unconformity at Site 742, but by probable lodgement till at Site 739, confirming that more extensive ice than that of the present day existed, at least for part of this period. This erosional phase also equates with a theorized time of maximum ice volume and discharge from the ice sheet at any time since its initiation (Robin, 1988). Near the McMurdo Sound drill sites, the Dry Valley Drilling Project recovered latest Miocene to early Pliocene gla- 


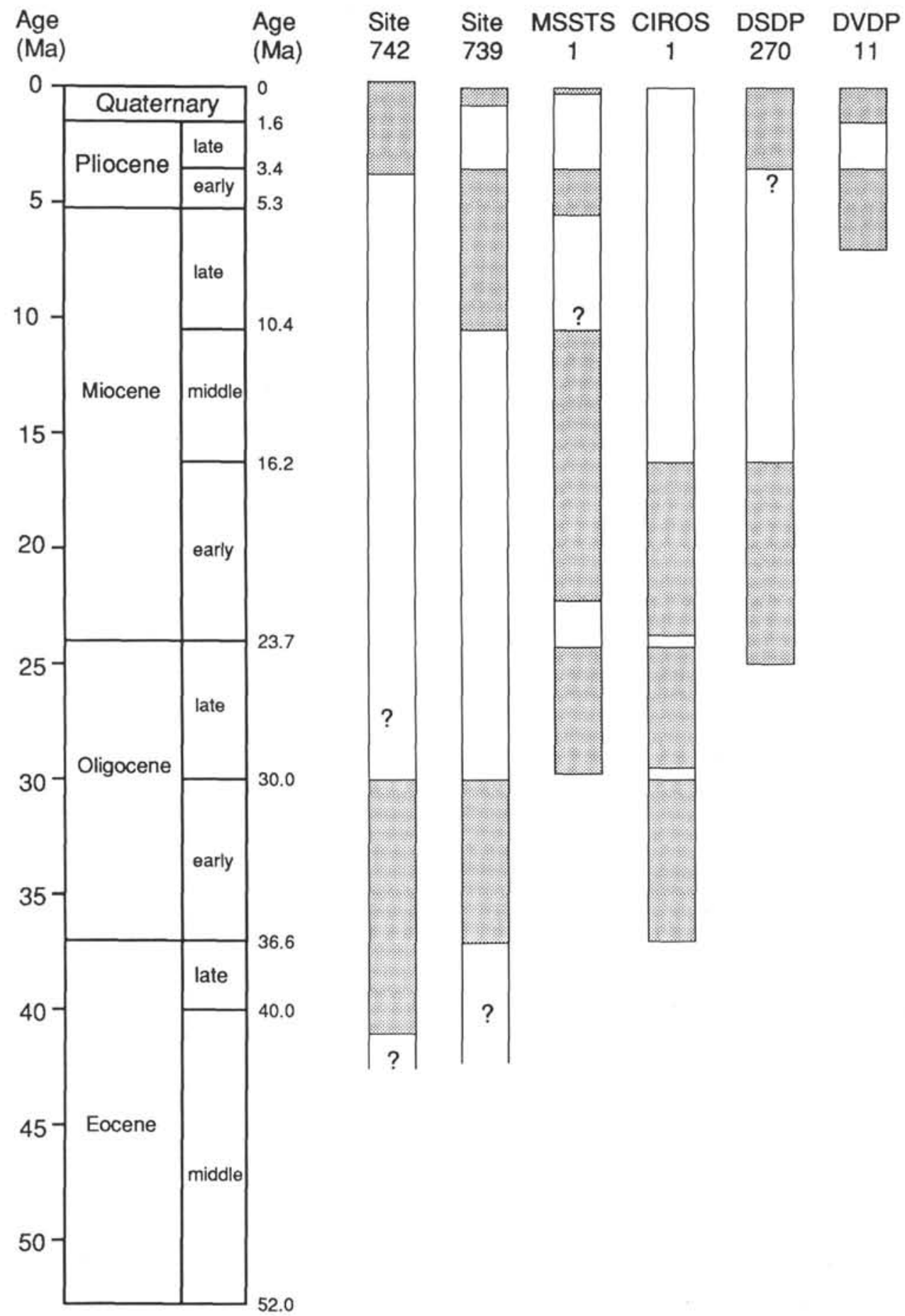

Figure 28. Stratigraphic intervals recovered from various drill holes on the east Antarctic continental margin: Sites 742 and 739, Prydz Bay; MSSTS-1, CIROS-1, DVDP-11, McMurdo Sound; and DSDP Site 270 in the outer Ross Sea.

ciomarine and grounded ice deposits (Elston and Bressler, 1981), and CIROS-2 recovered mainly early and mid Pliocene glaciogenic sediments in Ferrar Fjord (Barrett and Scientific Staff, 1985; Barrett, Hambrey, et al., in press). However, these events probably reflect advances of local ice from the Transantarctic Mountains rather than fluctuations of the main ice sheet.

In late early Pliocene to early late Pliocene time it is apparent from Site 742 in Prydz Bay that there was a glacial recession, but not total retreat of ice from coastal areas, with the deposi- tion of waterlain tills and a thin diatom-rich horizon containing ice-rafted material. On the ice-free Vestfold Hills, bordering Prydz Bay to the southeast, Pickard et al. (1988) reported marine sediments about 4.5 to $3.5 \mathrm{Ma}$ old (late early Pliocene). These contain diatoms and mollusks of strongly interglacial character and indicate a sea level that was $75 \mathrm{~m}$ higher over this site than today. The absence of significant ice-rafted material suggests an even more marked glacial recession than indicated by the Prydz Bay sediments. 
There is a variety of evidence from other parts of Antarctica indicating major collapse of the ice sheet at least once during early and late Pliocene time. The main evidence comes from the Sirius Formation, which is a terrestrial glacial deposit unconformably covering pre-Tertiary rocks, deposited high up in the Transantarctic Mountains. It contains reworked marine microfossils, including diatoms, foraminifers, radiolarians, and calcareous nannoplankton of late Miocene (Webb et al., 1984) or early Pliocene (Harwood, 1986) age. The Sirius microfossils were inferred to have been emplaced by latest Pliocene to Quaternary ice as it expanded and moved over the interior marine basins of East Antarctica toward the Transantarctic Mountains (Webb et al., 1984). Thus, it was hypothesized that deglaciation of late Miocene ice sheets created a marine seaway with warm waters across the middle of the continent between 5 and 2.5 m.y. ago (Harwood, 1986). A problem with this hypothesis is that ice should also have formed on the Transantarctic Mountains, and therefore flowed into the intervening basin, deflecting the interior ice as it flowed through the basin toward the shelf edge. Alternatively, it has been argued that wind transport was responsible for the microflora in the Sirius Formation, but this has been discounted by Burckle et al. (1988).

The Prydz Bay record neither confirms nor denies large-scale Pliocene deglaciation, and further data are needed, especially in view of the lack of evidence of major ice recession in the deepsea record.

The last few million years (latest Pliocene to Quaternary time), is poorly documented in most parts of Antarctica, and Prydz Bay is no exception. Better age constraints are needed, but it is evident that this was a major period of erosion of the shelf and a time of expanded ice sheets, during which most sedimentation was concentrated seaward of the shelf break. For the Holocene Epoch there is better information, a detailed chronology having been worked out by Domack and Jull (this volume). Their results indicate the development of open marine conditions in inner Prydz Bay around 10 k.y. BP, and a phase of increased ice-rafting between 7.3 and 3.8 k.y. BP.

\section{Comparison with the Southern Indian Ocean Ice-Rafting Record}

The ice-rafting record and other sediment parameters on the southern Kerguelen Plateau give additional information concerning the glacial history of East Antarctica. The first unequivocal ice-rafted material of Leg 119 Sites 744 and 738 occurs in early Oligocene sediments dating from about $36 \mathrm{Ma}$ (Ehrmann, this volume). Also, a change in the mode of carbonate deposition together with a change in the clay mineral assemblages and the appearance of significant amounts of diatoms indicates major climatic and paleoceanographic fluctuations due to the onset of glaciation at that time (Ehrmann, this volume). The earliest glaciers eroded large amounts of terrigenous weathering products, which were then transported onto the Prydz Bay shelf. Rafting by icebergs also led to much wider dispersal of sediment, to as far as the Kerguelen Plateau.

The Oligocene and Neogene hiatuses found in the sediments on Kerguelen Plateau (Barron, Larsen, et al., 1989; Baldauf and Barron, this volume) probably reflect the climatic deterioration and intensification of oceanic circulation.

Ice-rafted debris is found in all sediments younger than earliest Oligocene. From early Oligocene to late Miocene time, however, ice-rafted sediment only occurs in low quantities and is mainly silt sized, indicating that glaciers advanced to the East Antarctic shoreline throughout that time but that the supply of glacial debris was much smaller than during the very first pulse of glaciation in early Oligocene time, and smaller than during the latest Miocene to Holocene time interval (Ehrmann, this volume).
A distinct maximum in ice rafting has occurred from the latest Miocene to Holocene time. It correlates with a sharp decrease in carbonate deposition and the onset of intense diatom ooze sedimentation. These changes in sedimentation also suggest an intensification of Antarctic glaciation. The latest Miocene to present-day maximum in ice rafting cannot be resolved in detail at Sites 738 and 744 because of relatively low sedimentation rates. At Sites 745 and $\mathbf{7 4 6}$, in the Australian-Antarctic Basin, however, the ice-rafted material reveals concentration maxima in middle late Miocene, latest Miocene, earliest Pliocene, and late early to early late Pliocene time (Ehrmann et al., this volume). The same degree of resolution is not apparent in the Prydz Bay sites.

\section{Comparison with the Deep-Sea Oxygen Isotope Curve}

The major ice advances in Prydz Bay correlate with shifts in the $\delta^{18} \mathrm{O}$ curve of benthic and planktonic foraminifers (Miller et al., 1987; Shackleton and Kennett, 1975) to higher values. The most pronounced increase in $\delta^{18} \mathrm{O}$ occurs in association with a divergence in the planktonic and benthic values near the Eocene/Oligocene boundary. This shift seems to represent a major cooling event combined with the build up of large ice volumes on East Antarctica and the extension of a major glacier complex to the edge of the continental shelf in Prydz Bay. Oligocene to early Miocene isotopic values reveal only minor fluctuations and may indicate relatively stable ice conditions in Antarctica. An ice-free situation, as suggested by Miller et al. (1987), however, does not seem probable according to the Prydz Bay and CIROS-1 drilling results. Rather, these results support the ideas of Prentice and Matthews (1988), based on isotope data from the tropical regions, that the history of the earth during the past $40 \mathrm{Ma}$ was characterized by at least as great a volume of ice as exists today.

A further distinct increase in the oxygen isotope values in middle Miocene time coincides with a major hiatus defined paleontologically at Prydz Bay Sites 739 and 742. The undifferentiated Pleistocene glacial maxima recorded in the Prydz Bay sediments again correlates with $\mathrm{a}^{\cdot}$ drastic change in the oxygen isotope curves.

\section{Thermal Regime of Ice Sheet Through Time}

Differentiation of different types of former ice masses according to their thermal regime, whether temperate, subpolar, or polar, can be achieved if sufficient data are available concerning conditions on land. Questions that need to be asked include: what vegetation was developed, what evidence is there of meltwater, what is the character of weathering of the bedrock, and are there indications of frozen ground?

In the absence of direct evidence of climatic conditions on land, we need to turn to other indirect indications, such as composition and texture of the sediments, marine facies associations, and whether the glaciers were floating or grounded. The latter is important because if there is evidence of floating glacier ice, then the bulk of the ice is likely to have been below the pressure melting point; today temperate glaciers are invariably grounded when they enter the sea, whereas it is only cold glaciers that are able to float.

In Prydz Bay there are no direct indications of what the land was like at any time during glacial conditions, if indeed it was exposed at all. For example, no contemporaneous pollen has been recovered from the cores nor are any terrestrial sediments preserved. Clay mineralogy does indicate the presence of chemically weathered bedrock, but this presence probably indicates warmer, moister conditions prior to glaciation.

Grain-size characteristics of the sand and finer fraction of diamictites have been used as a measure of meltwater activity, and thus of the thermal regime of the glaciers that provided sed- 
iment to the CIROS-1 site in McMurdo Sound (Barrett, 1989b). The basis of this argument is that greater quantities of meltwater facilitate sliding of the ice over bedrock, thereby being a more effective scouring agent and creating more rock flour. The relative lack of meltwater today has given rise to sandier diamictites than is typical for late Pleistocene tills in the Northern Hemisphere, which were deposited in association with copious amounts of meltwater. Barrett (1989b) observed that the bulk of the diamictites in the Oligocene CIROS-1 core showed stronger similarities with the Pleistocene sediments than with contemporary diamictites in the same area. As the Pleistocene ice sheets were associated with abundant meltwater, and may have been temperate at their outer limits, he inferred that the Oligocene ice of the Ross Sea was probably temperate. This view was supported by an independent line of evidence-the presence of a Nothofagus (beech) leaf and pollen in the core.

A preliminary analysis of diamictites from Prydz Bay shows that they fall toward the sandy end of the field occupied by temperate glacier tills and compare closely with the data assembled by Barrett for Oligocene sediments in the McMurdo Sound cores (Fig. 29). This suggests that the Prydz Bay glaciers were also temperate, or at least associated with much more meltwater than today. However, a complicating factor in Prydz Bay is the change in character of the source rocks, indicated by a slowly increasing sand content up-sequence, as the proportion of basement material increases.

Another factor affecting grain size distribution in glacigenic sediments is the distance of transport. For example, J $\phi$ rgensen
(1977) demonstrated that Norwegian tills transported over short distances were markedly different from more distal tills deposited in Denmark. Indeed, the sandy character of the former, which also depended on the nature of the crystalline bedrock, is closer to that of the present-day tills from Antarctica, depicted in Figure 29. Therefore caution is necessary in arguing that the ice was temperate, in the absence of other evidence.

Another line of argument is that, to deposit thick, uniform sequences of massive diamictite, it is necessary to have deposition close to a relatively stable and preferably subsiding grounding line of a floating glacier. It is difficult to conceive how such sequences could have been deposited without being interbedded with other facies if the ice had been grounded. Whether or not floating temperate glaciers occurred in the past cannot be ascertained, but the absence of such glaciers today would suggest that the Prydz Bay diamictites were deposited from cold ice. This is at variance with the data previously mentioned.

In summary, we cannot, be certain about the thermal characteristics of the Prydz Bay glaciers, except that there was more meltwater than at the present day, and that there was a lower proportion of crystalline material being eroded. We require more independent lines of evidence of paleoclimate, as in McMurdo Sound, for a more accurate assessment.

\section{CONCLUSIONS}

Drilling through the glacial sequence in Prydz Bay has recovered a relatively limited range of facies. Massive diamict, most of which is interpreted as waterlain till, with some lodgement

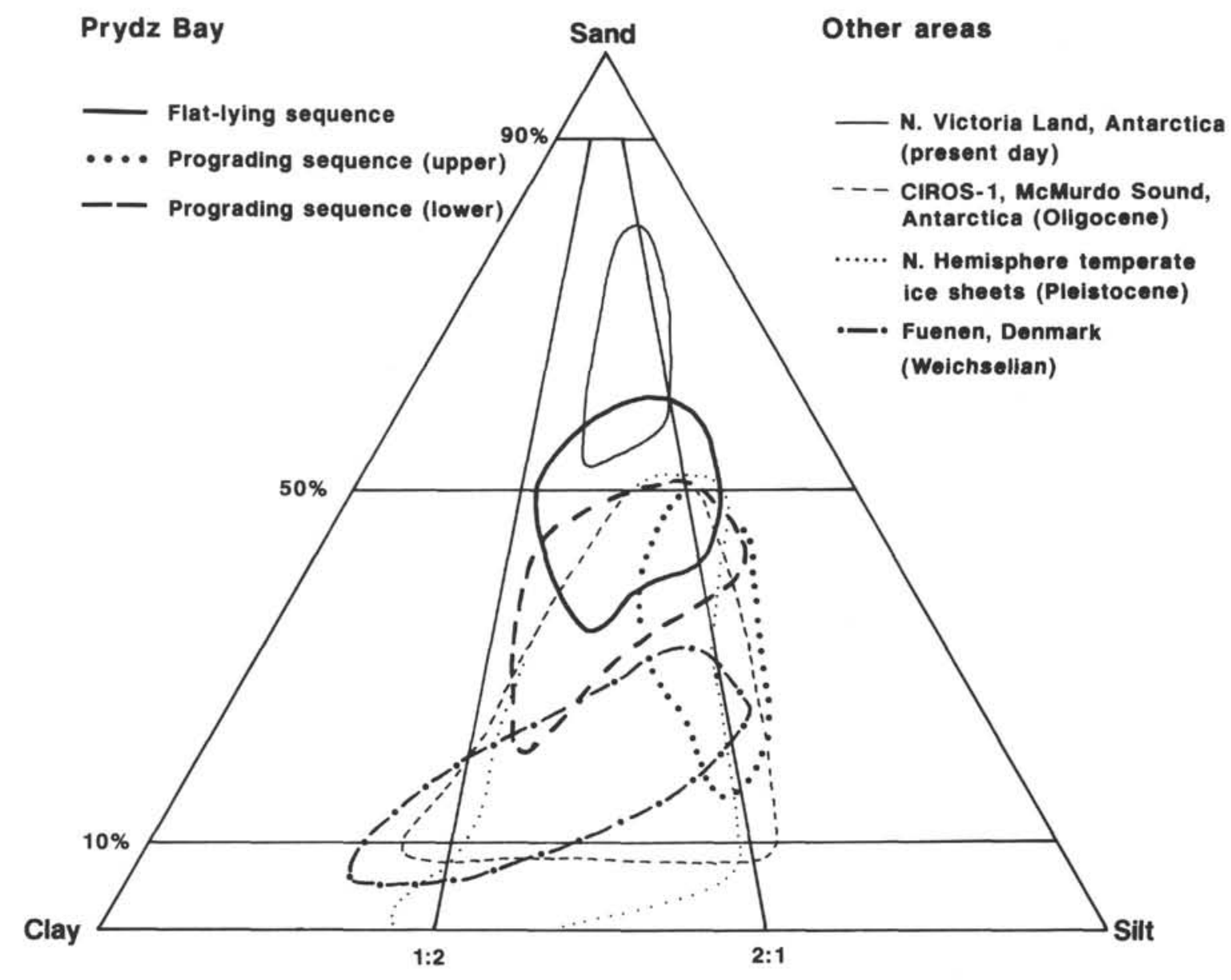

Figure 29. Comparison of grain-size distribution in diamictites from Prydz Bay with those from CIROS-1, McMurdo Sound, present-day northern Victoria Land, and from deposits of the Northern Hemisphere Pleistocene ice sheets. 
till, is by far the most abundant. Weakly stratified and wellstratified diamictites at some levels are interpreted as proximal and distal glaciomarine sediments, respectively. A few minor facies include poorly sorted sandstone and mudstone, diatom ooze, and diatomite, each of them representing distal glaciomarine facies. No facies lacking signs of influence from ice were recovered, although such facies may have been lost during drilling.

On the basis of the interpretation of these sediments in a glacial context, and through consideration of the seismic, physicalproperties and downhole logging data, the following chronology for ice sheet behavior and continental shelf growth has been determined.

The results from Leg 119 drilling indicate that East Antarctica was under the influence of an extensive ice sheet by at least earliest Oligocene time. At this time, the forerunner of today's Lambert Glacier-Amery ice shelf complex extended out from the Lambert Graben and became grounded near Sites 739 and 742 , which were then located near the shelf break. Waterlain tills were deposited just seaward of the grounding line of the glacier as it decoupled from the bed. This represents a distance of approximately $550 \mathrm{~km}$ from the present-grounding line, and implies that, if the ice was to maintain a steady-state profile, it would have been substantially thicker than the present ice sheet. Early Oligocene glaciation in Prydz Bay is matched by ice conditions in McMurdo Sound that were occasionally more extensive than those of today, but which have been related to tectonic uplift of the Transantarctic Mountains, rather than global climatic changes. Further confirmation of continental-scale early Oligocene glaciation comes from the ice-rafting record from the southern Kerguelen Plateau (Ehrmann, this volume) and from the Weddell Sea (Barker, Kennett, et al., 1988).

Several hundred meters of glaciogenic sediment accumulated as the continental shelf prograded throughout early Oligocene time. The late Oligocene to mid-Miocene record was not drilled in Prydz Bay, but progradation continued, presumably under the influence of a still-growing ice sheet. This phase of more extensive glaciation is documented in McMurdo Sound by several major ice advances across the shelf in that area.

In Prydz Bay, a major hiatus formed on top of the prograding sequence. This is of variable age. In the inner shelf, the unconformity spans the interval from Mesozoic (undefined, possibly Triassic; Turner, this volume) to Pliocene-Pleistocene. At Site 742 the time span is early Oligocene to late early Pliocene, and at Site 739 late Oligocene to late Miocene. The overlying flat-lying sequence comprises ice recessional facies, including distal glaciomarine sediments, associated with ice-proximal facies, suggesting major fluctuations of the ice margin across the shelf in late Miocene and mid-Pliocene time. Some of these may be linked with major recession(s) of the East Antarctic ice sheet in early or late Pliocene time, as has been documented in other parts of the Antarctic, notably the Transantarctic Mountains and the Vestfold Hills bordering Prydz Bay.

Late Pliocene-Pleistocene events are poorly constrained temporally, but were dominated by successive advances of ice across the shelf and continued build up and periodic loading of the flat-lying sequence and especially by resumed progradation of the shelf margin under the influence of the ice sheet as it again became decoupled from the bed. Finally, after the retreat of the last late Wisconsinan/Weichselian ice sheet, shelf processes were restricted mainly to siliceous biogenic and minor iceberg rafting, and the continental slope became starved of its supply of sediment.

The onset of glaciation at sea level in Antarctica is still an open question, as the base of the glacial sequences cored so far have not been reached nor have the oldest Prydz Bay glacial sediments been well dated. However, there can be no doubt that full-scale glaciation was underway by early Oligocene time. We also know that Prydz Bay was under the influence of a fluvial regime with a temperate woodland climate in mid-Cretaceous time (Turner, this volume). Thus, to finally resolve the question we need access to a good offshore Late Cretaceous to Eocene sedimentary record.

The question concerning the timing of the initial development of the East Antarctic ice sheet cannot be determined precisely, as its influence on the marine environment for that period of time during which it failed to reach the sea may not be obvious. As mentioned in the Introduction, the evidence for glaciation in Cretaceous time is conflicting. However, even if warm conditions prevailed at the fringes of Antarctica, it is conceivable that, in view of the high elevation of the continent, large ice caps could have existed while it was located over the South Polar region. Indeed, some ice may have existed on Antarctica throughout much of the Phanerozoic Eon, even though evidence of full-scale glaciation prior to Cenozoic Era is limited to the Carboniferous and Permian periods.

The response of the Antarctic ice sheet to climatic change is a critical problem for mankind. The concern that the greenhouse warming will lead to global sea-level rise of catastrophic proportions is a problem that can be addressed by examination of the glacial sedimentary record. The evidence from Prydz Bay of more extensive ice throughout much of the Oligocene Epoch than today, seems to coincide with relatively high temperatures derived from the deep-sea record. The association of more extensive ice under a warmer climate is even more evident in the Oligocene sequence in McMurdo Sound. Thus, even if the ice shelves themselves retreat rapidly when climate warms, there may in fact be a net build up of ice through greater precipitation as snow on East Antarctica, as the geologically constrained glaciological model of Robin (1988) demonstrates. Understanding of the complexities of the interaction between ice, climate, and sedimentation is still at an earlier stage, and future research in this field in Antarctica should be directed toward a better understanding of the processes involved.

\section{ACKNOWLEDGMENTS}

The participation of the authors in the Leg 119 cruise was made possible as a result of funding by the UK Natural Environment Research Council (MJH), by the Alfred Wegener Institute and the Deutsche Forschungsgemeinschaft (WUE), and by the Danish Natural Science Research Council (BL). The shorebased investigations were supported by Grant Fu 119/15 of the Deutsche Forschungsgemeinschaft and by NATO Research Grant $0232 / 89$. The manuscript was prepared during the tenure of $\mathrm{MJH}$ as a Guest Scientist at the Alfred Wegener Institute for Polar and Marine Research, and sincere thanks are offered to Prof. Dr. D. K. Fütterer for making this possible.

We thank R. Fröhlking, A. Hienen, and I. Engelbrecht (Alfred Wegener Institute) and A. C. Nielsen and K. Schultz (Danmarks Tekniske $\mathrm{H} \phi$ jskole) for assisting with analysis of the samples. We further thank Dr. P. J. Barrett, Dr. A. Cooper, Dr. A. Solheim, G. Ollier, and Dr. H. Grobe for helpful discussions and comments on the manuscript and the Leg 119 scientific and technical staff for general advice and assistance.

This is Contribution No. 287 of the Alfred Wegener Institute for Polar and Marine Research.

\section{REFERENCES}

Alley, R. B., Blankenship, D. D., Rooney, S. T., and Bentley, C. R., 1989. Sedimentation beneath ice shelves-the view from Ice Stream B. Mar. Geol., 85:101-120.

Allison, I. F., 1979. The mass budget of the Lambert Glacier drainage basin, Antarctica. J. Glaciol., 22:223-235. 
Anderson, J. B., 1983. Ancient glacial-marine deposits: their spatial and temporal distribution. In Molnia, B. F. (Ed.), Glacial-Marine Sedimentation: New York (Plenum Press), 10-92.

Anderson, J. B., Brake, C., Domack, E., Myers, N., and Wright, R., 1983. Development of a polar glacial-marine sedimentation model from Antarctic Quaternary deposits and glaciological information. In Molnia, B. F. (Ed.), Glacial-Marine Sedimentation: New York (Plenum Press), 233-264.

Anderson, J. B., Domack, E. W., and Kurtz, D. D., 1980a. Observation of sediment-laden icebergs in Antarctic waters: implications to glacial erosion and transport. J. Glaciol., 25:387-396.

Anderson, J. B., Kurtz, D. D., Domack, E. W., and Balshaw, K. M., 1980. Glacial and glacial marine sediments of the Antarctic continental shelf. J. Geol., 88:399-414.

Anderson, J. B., Kurtz, D. D., and Weaver, F. M., 1979. Sedimentation on the Antarctic continental slope. In Doyle, L. J., and Pilkey, O. H. (Eds.), Geology of Continental Slopes. Spec. Publ. Soc. Econ. Paleont. Mineral., 27:61-73.

Anderson, J. B., and Molnia, B. F., 1989. Glacial-Marine Sedimentation. Am. Geophys. Union Short Course in Geol., 9.

Anderson, J. B., and Smith, M. J., 1989. Formation of modern sandrich facies by marine currents on the Antarctic continental shelf. GCSSEPM Found. 7th Annu. Res. Conf. Proc., 41-52.

Andrews, J. T., and Matsch, C. L., 1983. Glacial Marine Sediments and Sedimentation: Norwich (Geo. Abstracts Ltd.).

Bardin, V. I., 1982. Composition of East Antarctic moraines and some problems of Cenozoic history. In Craddock, C. (Ed.), Antarctic Geoscience: Madison (Univ. of Wisconsin Press), 1069-1076.

Bardin, V. I., Bubnova, M. I., and Gerasimova, V. M., 1979. Clay minerals in unconsolidated deposits of the Prince Charles Mountains. Soviet. Antarct. Exped. Inf. Bull. Engl. Trans., 71:120-128.

Barker, P. F., Kennett, J. P., and Leg 113 Shipboard Scientific Party, 1988. Weddell Sea palaeoceanography: preliminary results of ODP Leg 113. Palaeogeogr., Palaeoclimatol., Palaeoecol., 67:75-102.

Barrett, P. J. (Ed.), 1986. Antarctic Cenozoic history from the MSSTS-1 drillhole, McMurdo Sound. DSIR Bull., 237.

(Ed.), 1989a. Antarctic Cenozoic history from the CIROS-1 drillhole, McMurdo Sound. DSIR Bull., 245.

1989b. Sediment texture. In Barrett, P. J. (Ed.), Antarctic Cenozoic History from the CIROS-1 Drillhole, McMurdo Sound: DSIR Bull., 245:49-58.

Barrett, P. J., Elston, D. P., Harwood, D. M., McKelvey, B. C., and Webb, P. N., 1987. Mid-Cenozoic record of glaciation and sea level change on the margin of the Victoria Land Basin, Antarctica. Geology, 15:634-637.

Barrett, P. J., and Hambrey, M. J., in press. Sedimentary processes in a high polar fjord setting: Ferrar Fjord, Ross Sea, Antarctica. Sedimentology.

Barrett, P. J., Hambrey, M. J., Harwood, D. M., Pyne, A. R., and Webb, P.-N., 1989. Synthesis. In Barrett, P. J. (Ed.), Antarctic Cenozoic History from the CIROS-1 Drillhole, McMurdo Sound: DSIR Bull., 245:241-251.

Barrett, P. J., Hambrey, M. J., and Robinson, P. H., in press. Cenozoic glacial and tectonic history of CIROS-1, McMurdo Sound. In Thompson, M.R.A., Crame, J. A., and Thompson, J. W. (Eds.), Geological Evolution of Antarctica: Cambridge (Cambridge Univ. Press).

Barrett, P. J., Pyne, A. R., and Ward, B. L., 1983. Modern sedimentation in McMurdo Sound, Antarctica. In Oliver, R. L., James, P. R., and Jago, J. B. (Eds.), Antarctic Earth Sciences: Cambridge (Cambridge Univ. Press), 550-554.

Barrett, P. J., and Scientific Staff, 1985. Plio-Pleistocene glacial sequence cored at CIROS-2, Ferrar Fjord, McMurdo Sound. N. Z. Antarct. Rec., 6:8-19.

Barron, J., Larsen, B., et al., 1989. Proc. ODP, Init. Repts., 119: College Station, TX (Ocean Drilling Program).

Birkenmajer, K., 1987. Oligocene-Miocene glacio-marine sequences of King George Island (South Shetland Islands), Antarctica. Palaeontol. Polonica, 49:9-36.

Biscaye, P. E., 1964. Distinction between kaolinite and chlorite in recent sediments by X-ray diffraction. Am. Miner., 49:1281-1289.

, 1965. Mineralogy and sedimentation of recent deep-sea clay in the Atlantic Ocean and adjacent seas and oceans. Geol. Soc. Am. Bull., 76:803- 832.
Bjørlykke, K., Bue, B., and Elverhøi, A., 1978. Quaternary sediments in the western part of the Barents Sea and their relation to the underlying Mesozoic bedrock. Sedimentology, 25:227-246.

Bornhold, B. D., and Guilcher, A. (Eds.), 1984. Sedimentation on high latitude continental shelves. Mar. Geol., Spec. Iss., 57.

Borns, H. W., and Matsch, C. L., 1988. A provisional genetic classification of glaciomarine environments, processes, and sediments. In Goldthwhaite, R. P., and Matsch, C. L. (Eds.), Genetic Classification of Glacigenic Deposits: Rotterdam (Balkema), 261-266.

Boulton, G. S., and Deynoux, M., 1981. Sedimentation in glacial environments and the identification of tills and tillites in ancient sedimentary sequences. Precambrian Res., 15:397-422.

Brindley, G. W., and Brown, G. (Eds.), 1980. Crystal Structures of Clay Minerals and Their X-ray Identification. Mineral. Soc. Monogr., 5.

Burckle, L. H., Gayley, R. I., Ram, M., and Petit, J.-R., 1988. Diatoms in Antarctic ice cores: some implications for the glacial history of Antarctica. Geology, 16:326-329.

Campbell, I. B., and Claridge, G.G.C., 1987. Antarctica: Soils, Weathering Processes and Environment: Amsterdam (Elsevier).

Carey, S. W., and Ahmad, N., 1961. Glacial marine sedimentation. Ist Inter. Symp. on Arctic Geol. Proc., 2:865-894.

Chamley, H., 1989. Clay Sedimentology: Berlin (Springer).

Claridge, G.G.C., and Campbell, J. B., 1989. Clay mineralogy. In Barrett, P. J. (Ed.), Antarctic Cenozoic History from the CIROS-1 Drillhole, McMurdo Sound: DSIR Bull., 245:185-193.

Cooper, A. K., and Davey, F. J. (Eds.), 1987. The Antarctic Continental Margin: Geology and Geophysics of the Western Ross Sea: Houston (Circum-Pacific Council for Energy and Mineral Resources), Earth Sci. Ser., Vol. 5B.

Craddock, C., 1982. Geological map of Antarctica. In Craddock, C. (Ed.), Antarctic Geoscience: Madison (Univ. Wisconsin Press).

Domack, E. W., 1988. Biogenic facies in the Antarctic glacimarine environment: basis for a polar glacimarine summary. Palaeogeogr., $\mathrm{Pa}$ laeoclimatol., Palaeoecol., 63:357-372.

Domack, E. W., Anderson, J. B., and Kurtz, D. D., 1980. Clast shape as an indicator of transport and depositional mechanisms in glacial marine sediments: George V Continental Shelf, Antarctica. J. Sediment. Petrol., 59:813-820.

Domack, E. W., and Lawson, D. E., 1985. Pebble fabric in an ice-rafted diamicton. J. Geol., 93:577-591.

Dowdeswell, J. A., 1987. Processes of glacimarine sedimentation. Prog. Phys. Geogr., 11:52-90.

Dowdeswell, J. A., and Dowdeswell, E. K., 1989. Iceberg sedimentation rates: observations and a simple model. J. Geol., 97:223-233.

Dowdeswell, J. A., Hambrey, M. J., and Wu, R. T., 1985. Clast shape and fabric in Precambrian and modern glacigenic sediments. J. Sediment. Petrol., 55:691-704.

Dowdeswell, J. A., and Sharp, M. J., 1986. The characterization of pebble fabrics in modern glacigenic sediments. Sedimentology, 33:699710 .

Dreimanis, A., 1976. Tills: their origin and properties. In Leggett, R. F. (Ed.), Glacial Till: Roy. Soc. Can. Spec. Publ., 12:11-49.

1988. Tills: their genetic terminology and classification. In Goldthwaite, R. P., and Matsch, C. L. (Eds.), Genetic Classification of Glacigenic Deposits: Rotterdam (Balkema), 17-83.

Drewry, D. J., 1986. Glacial Geological Processes: London (Arnold).

Drewry, D. J., and Cooper, A.P.R., 1981. Processes and models of Antarctic glaciomarine sedimentation. Ann. Glaciol., 2:117-122.

Dunbar, R. B., Anderson, J. B., and Domack, E. W., 1985. Oceanographic influences on sedimentation along the Antarctic continental shelf. In Oceanology of the Antarctic Continental Shelf. Am. Geophys. Union Antarctic Res. Ser., 43:291-312.

Dunbar, R. B., Leventer, A. R., and Stockton, W. L., 1989. Biogenic sedimentation in McMurdo Sound, Antarctica. Mar. Geol., 85:155-179.

Elston, D. P., and Bressler, S. C., 1981. Magnetic stratigraphy of DVDP drill cores and late Cenozoic history of Taylor Valley, Transantarctic Mountains, Antarctica. In McGinnis, L. D. (Ed.), Dry Valley Drilling Project: Am. Geophys. Union Antarctic Res. Ser., 33:413-426.

Elverhøi, A., 1984. Glacigenic and associated marine sediments in the Weddell Sea, fjords of Spitsbergen and the Barents Sea: a review. Mar. Geol., 57:53-88.

Elverhøi, A., Lonne, O., and Seland, R., 1983. Glaciomarine sedimentation in a modern fjord environment, Spitsbergen. Polar Res., 1: $127-149$. 
Elverhøi, A., Pfirman, S. L., Solheim, A., and Larsen, B. B., 1989. Glaciomarine sedimentation in epicontinental seas exemplified by the northern Barents Sea. Mar. Geol., 85:225-250.

Elverhøi, A., and Roaldset, E., 1983. Glaciomarine sediments and suspended particulate matter, Weddell Sea Shelf, Antarctica. Polar Res., 1:1-21.

Eyles, N., Eyles, C. H., and Miall, A. D., 1983. Lithofacies types and vertical profile models; an alternative approach to the description and environmental interpretation of glacial diamict and diamictic sequences. Sedimentology, 30:393-410.

1985. Models of glaciomarine sedimentation and their application to the interpretation of ancient glacial sequences. Palaeogeogr., Palaeoclimatol., Palaeoecol., 51:15-84.

Fedorov, L. V., Grikurov, G. E., Kurinin, R. G., and Masolov, V. N., 1982a. Crustal structure of the Lambert Graben area from geophysical data. In Craddock, C. (Ed.), Antarctic Geoscience: Madison, WI (Univ. of Wisconsin Press), 931-936.

Fedorov, L. V., Ravich, M. G., and Hofmann, J., 1982b. Geological comparison of southeastern peninsular India and Sri Lanka with part of East Antarctica (Enderby Land, MacRobertson Land, and Princess Elizabeth Land). In Craddock, C. (Ed.), Antarctic Geoscience: Madison, WI (Univ. of Wisconsin Press), 73-78.

Flint, R. F., Sanders, J. E., and Rodgers, J., 1960a. Symmictite: a name for non-sorted terrigenous sedimentary rocks that contain a wide range of particle sizes. Geol. Soc. Am. Bull., 71:507-509.

1960b. Diamictite, a substitute term for symmictite. Geol Soc. Am. Bull., 71:1809.

Folk, R. L., 1966. A review of grain-size parameters. Sedimentology, 6: 73-93

Frakes, L. A., and Francis, J. E., 1988. A guide to Phanerozoic cold polar climates from high-latitude ice-rafting in the Cretaceous. Nature, 339:547-549.

Fütterer, D. K., Grobe, H., and Grünig, S., 1988. Quaternary sediment patterns in the Weddell Sea: relations and environmental conditions. Paleoceanography, 3:551-561.

Fütterer, D. K., and Melles, M., 1990. Sediment patterns in the southern Weddell Sea: Filchner Shelf and Filchner Depression. In Bleil, U., and Thiede, J. (Eds.), Geological History of Polar Oceans: Arctic versus Antarctic. NATO/ASI Series C. Dordrecht (Kluwer Academic Publishers), 381-401.

Gazdzicki, A., 1989. Planktonic foraminifera from the Oligocene Polonez Cove Formation of King George Island, West Antarctica. Pol. Polar Res., 10:47-55.

Gibbard, P., 1980. The origin of the Catfish Creek till by basal melting. Boreas, 9:71-85.

Goldthwaite, R. P., and Matsch, C. L. (Eds.), 1988. Genetic Classification of Glacigenic Deposits: Rotterdam (Balkema).

Gravenor, C. P., Von Brunn, V., and Dreimanis, A., 1984. Nature and classification of waterlain glaciogenic sediments, exemplified by Pleistocene, Late Paleozoic and Late Precambrian deposits. Earth Sci. Rev., 20:105-166.

Griffin, J. J., Windom, H., and Goldberg, E. D., 1968. The distribution of clay minerals in the World Ocean. Deep-Sea Res. Oceanogr. Abstr., 15:433-459.

Griffith, T. W., and Anderson, J. B., 1989. Climatic control of sedimentation in bays and fjords of the northern Antarctic Peninsula. Mar. Geol., 85:181-204.

Grobe, H., 1986a. Sedimentation processes on the Antarctic continental margin at Kapp Norvegia during the Late Pleistocene. Geol. Rundsch., 75:97-104.

1986b. Spätpleistozäne Sedimentationsprozesse am Antarktischen Kontinentalhang vor Kapp Norvegia, Östliche Weddell See. Rep. Polar Res., 27.

Haase, G. H., 1986. Glaciomarine sediments along the Filchner/Ronne Ice Shelf, southern Weddell Sea-first results of the 1983/84 Antarktis-II/4 Expedition. Mar. Geol., 72:241-258.

Hambrey, M. J., 1989. Grain fabric studies on the CIROS-1 core. In Barrett, P. J. (Ed.), Antarctic Cenozoic History from the CIROS-I Drillhole, McMurdo Sound: DSIR Bull., 245:59-62.

Hambrey, M. J., Barrett, P. J., and Robinson, P. H., 1989. Stratigraphy. In Barrett, P. J. (Ed.), Antarctic Cenozoic History from the CIROS1 Drillhole, McMurdo Sound: DSIR Bull., 245:23-48.

Hambrey, M. J., and Harland, W. B., 1981. Earth's Pre-Pleistocene Glacial Record: Cambridge (Cambridge Univ. Press).
Hambrey, M. J., Larsen, B., Ehrmann, W. U., and ODP Leg 119 Shipboard Scientific Party, 1989. Forty million years of Antarctic glacial history yielded by Leg 119 of the Ocean Drilling Program. Polar Rec., 25:99-106.

Harland, W. B., Herod, K. N., and Krinsley, D. H., 1966. The definition and identification of tills and tillites. Earth Sci. Rev., 2:225-256.

Harwood, D. M., 1986. Recycled siliceous microfossils from the Sirius Formation. Antarctic J. U.S., 21:101-103.

Hayes, D. E., Frakes, L. A., et al., 1975. Init. Repts. DSDP, 28: Washington (U.S. Govt. Printing Office).

Hill, R. S., 1989. Fossil leaf. In Barrett, P. J. (Ed.), Antarctic Cenozoic History from the CIROS-1 Drillhole, McMurdo Sound: DSIR Bull., 245:143-144.

Ivanov, V. I., 1983. Sedimentary basins of Antarctica and their preliminary structural and morphological classification. In Oliver, R. L., James, P. R., and Jago, J. B. (Eds.), Antarctic Earth Science: Cambridge (Cambridge Univ. Press), 539-541.

Jefferson, T. H., 1982. Fossil floras from the Lower Cretaceous of Alexander Island, Antarctica. Paleontology, 25:681-708.

Jørgensen, P., 1977. Some properties of Norwegian tills. Boreas, 6:149157

Kellogg, T. B., and Kellogg, D. E., 1988. Antarctic cryogenic sediments: biotic and inorganic facies of ice shelf and marine-based ice sheet environments. Palaeogeogr., Palaeoclimatol, Palaeoecol., 67:51-74.

Kennedy, D. S., and Anderson, J. B., 1989. Glacial-marine sedimentation and Quaternary glacial history of Marguerite Bay, Antarctic Peninsula. Quat. Res., 31:255-276.

King, H. L., Kokoengen, K., and Gunleiksrud, T., 1987. Quaternary seismostratigraphy of the Mid Norwegian Shelf, $65^{\circ}-67^{\circ} 30^{1 / 2} \mathrm{~N}-$ till tongue stratigraphy. IKU Publ., 114

Lange, H., 1982. Distribution of chlorite and kaolinite in eastern Atlantic sediments off North Africa. Sedimentology, 29:427-432.

Larter, R. D., and Barker, P. F., 1989. Seismic stratigraphy of the Antarctic Peninsula Pacific margin: a record of Pliocene-Pleistocene ice volume and paleoclimate. Geology, 17:731-734.

Lawson, D. E., 1981. Sedimentological Characteristics and Classification of Depositional Processes and Deposits in the Glacial Environment: Hannover, New Hampshire (Cold Regions Research and Engineering Laboratory), Report 81-27.

Leg 113 Shipboard Scientific Party, 1987. Glacial history of Antarctica. Nature, 328:115-116.

Leg 119 Shipboard Scientific Party, 1988. Leg 119 studies climatic history. Geotimes, July 1988:14-16.

Lisitzin, A. P., 1972. Sedimentation in the World Ocean, with Emphasis on the Nature, Distribution and Behavior of Marine Suspensions. Soc. Econ. Paleontol. Mineral Spec. Publ., 17.

Mackiewicz, N. E., Powell, R. D., Carlson, P. R., and Molnia, B. F., 1984. Interlaminated ice-proximal glacimarine sediments in Muir Inlet, Alaska. Mar. Geol., 57:113-147.

Matthews, R. K., and Poore, R. Z., 1980. Tertiary $\delta^{18} \mathrm{O}$ record and glacioeustatic sea-level fluctuations. Geology, 8:501-504.

McGinnis, L. D. (Ed.), 1981. Dry Valley Drilling Project: Am. Geophys. Union Antarctic Res. Ser., 33.

McIntyre, N. F., 1985. A re-assessment of the mass balance of the Lambert Glacier drainage basin, Antarctica. J. Glaciol., 31:34-38.

Melles, M., 1987. Sedimentation in der Filchner-Depression, südöstlicher Weddellmeer-Schelf, Antarktis [Dipl. Arb., unpubl.]. Univ. Göttingen.

Mildenhall, D. C., 1989. Terrestrial palynology. In Barrett, P. J. (Ed.), Antarctic Cenozoic History from the CIROS-1 Drillhole, McMurdo Sound: DSIR Bull., 245:119-127.

Miller, K. G., Fairbanks, R. G., and Mountain, G. S., 1987. Tertiary oxygen isotope synthesis, sea-level history, and continental margin erosion. Paleoceanography, 2:1-19.

Mizukoshi, I., Sunouchi, H., Saki, T., Sato, S., and Tanahashi, M., 1988. Preliminary report of geological geophysical surveys off Amery Ice Shelf, East Antarctica. Mem. Nat. Inst. Polar Res. Spec. Iss. Jpn., 43:48-61.

Molnia, B. F. (Ed.), 1983. Glacial-Marine Sedimentation: New York (Plenum Press).

Moncrieff, A.C.M., 1989. Classification of poorly-sorted sedimentary rocks. Sediment. Geol., 65:191-194.

Moncrieff, A.C.M., and Hambrey, M. J., 1990. Marginal marine glacial sedimentation in the late Precambrian succession of East Greenland. 
In Dowdeswell, J. A. and Scourse, J. D., (Eds.), Glacimarine Environments: Processes and Products: Geol. Soc. Spec. Publ. London, $53: 387-410$.

Murray, J., and Renard, A. F., 1891. Report on Deep-sea Deposits. Report on the Scientific Results of the Voyage of HMS Challenger 1873-76: London (Her Majesty's Stationery Office).

Paterson, W.S.B., 1981. The Physics of Glaciers: Oxford (Pergamon Press).

Pickard, J., Adamson, D. A., Harwood, D. M., Miller, G. H., Quilty, P. G., and Dell, R. K., 1988. Early Pliocene marine sediments, coastline, and climate of East Antarctica. Geology, 16:151-161.

Porebski, S. J., and Gradzinski, R., 1987. Depositional environment of the Polonez Cove Formation (Oligocene), King George Island, West Antarctica: a record of continental glaciation, shallow-marine sedimentation and contemporary volcanism. Stud. Geol. Polonica, 93: $7-62$.

Powell, R. D., 1981. A model for sedimentation by tidewater glaciers. Ann. Glaciol., 2:129-134.

1983. Glacial-marine sedimentation processes and lithofacies of temperate tidewater glaciers, Glacier Bay, Alaska. In Molnia, B. F. (Ed.), Glacial-Marine Sedimentation: New York (Plenum Press), 185232.

1984. Glacimarine processes and inductive lithofacies modelling of ice shelf and tidewater glacier sediments based on Quaternary examples. Mar. Geol., 57:1-52.

Powell, R. D., and Elverhøi, A. (Eds.), 1989. Modern Glacimarine Environments: Glacial and Marine Controls of Modern Lithofacies and Biofacies: Mar. Geol., Spec. Iss., 85:101-416.

Powell, R. D., and Molnia, B. F., 1989. Glacimarine sedimentation processes, facies and morphology of the south-southeast Alaska shelf and fjords. Mar. Geol., 85:359-390.

Prentice, M. L., and Matthews, R. K., 1988. Cenozoic ice-volume history: development of a composite oxygen isotope record. Geology, 16:963-966.

Quilty, P. G., 1985. Distribution of foraminiferids in sediments of Prydz Bay, Antarctica. Spec. Publ. S. Aust. Dep. Mines Energy, 5:329340.

Ravich, M. G., and Fedorov, L. V., 1982. Geologic structure of MacRobertson Land and Princess Elizabeth Land, East Antarctica. In Craddock, C. (Ed.), Antarctic Geoscience: Madison (Univ. Wisconsin Press), 499-504.

Ravich, M. G., Solov'ev, D. S., and Fedorov, L. V., 1984. Geological Structure of Mac. Robertson Land (East Antarctica): New Delhi (Amerind Publishing). [Translated from Russian and published for the Division of Polar Programs National Science Foundation, Washington D.C.]

Robin, G. de Q., 1988. The Antarctic ice sheet, its history and response to sea level and climatic changes over the past 100 million years. $P a$ laeogeogr., Palaeoclimatol., Palaeoecol., 67:31-50.

Robinson, P. H., Pyne, A., Hambrey, M. J., Hall, K. J., and Barrett, P. J., 1987. Core Logs, Photographs and Grain Size Analyses from the CIROS-1 Drillhole, McMurdo Sound, Antarctica. Antarctic Data Ser., Victoria Univ. of Wellington.

Savage, M. L., and Ciesielski, P. F., 1983. A revised history of glacial sediments in the Ross Sea region. In Oliver, R. L., James, P. R., and Jago, J. B. (Eds.), Antarctic Earth Science: Cambridge (Cambridge Univ. Press), 555-559.

Shackleton, N. J., 1986. Palaeogene stable isotope events. Palaeogeogr., Palaeoclimatol., Palaeoecol., 57:91-102.

Shackleton, N. J., and Kennett, J. P., 1975. Paleotemperature history of the Cenozoic and the initiation of Antarctic glaciation: oxygen and carbon isotope analyses in DSDP Sites 277, 279 and 281. In Kennett, J. P., Houtz, R. E., et al., Init. Repts. DSDP, 29: Washington (U.S. Govt. Printing Office), 743-755.

Stagg, H.M.J., 1985. The structure and origin of Prydz Bay and MacRobertson Shelf, East Antarctica. Tectonophysics, 114:315-340.

Swithinbank, C.W.M., 1988. Satellite Image Atlas of the World: Antarctica. Geol. Surv. Prof. Pap. U.S., 1386-B.

Syvistski, J.P.M., and Skei, J. M. (Eds.), 1983. Sedimentology of fjords. Sedimentary Geology, 36:75-342.

Trail, D. S., and McLeod, I. R., 1969. Geology of the Lambert Glacier region. In Craddock, C. (Ed.), Geologic Maps of Antarctica. Am. Geogr. Soc., Antarctic Map Folio Ser., Folio 12, Plate XI.

Udinstev, G. B. (Ed.), 1975. Geological-Geophysical Atlas of the Indian Ocean. Moscow (Acad. Science USSR).
Vorren, T. O., Lebesbye, E., Andreassen, K., and Larsen, K.-B., 1989. Glacigenic sediments on a passive continental margin as exemplified by the Barents Sea. Mar. Geol., 85:251-272.

Webb, P. N., Harwood, D. M., McKelvey, B. C., Mercer, J. N., and Stott, L. D., 1984. Cenozoic marine sedimentation and ice-volume variation on the East Antarctic craton. Geology, 12:287-291.

Wright, R., and Anderson, J. B., 1982. The importance of sediment gravity flow to sediment transport and sorting in a glacial marine environment: Weddell Sea, Antarctica. Geol. Soc. Am. Bull., 93:951963.

Wright, R., Anderson, J. B., and Fisco, P. P., 1983. Distribution and association of sediment gravity flow deposits and glacial/glacial-marine sediments around the continental margin of Antarctica. In Molnia, B. F. (Ed.), Glacial-Marine Sedimentation: New York (Plenum), 265-300.

Date of initial receipt: 13 November 1989

Date of acceptance: 4 June 1990

Ms 119B-200

\section{APPENDIX G \\ Stratigraphic Descriptions of Prydz Bay Sites 739-743, Including Comparisons with Physical Properties, Downhole Logging, and Seismic Data}

This section provides a synthesis of all stratigraphic data from the Prydz Bay sites, which are described from the inner shelf out to the continental slope. Lithologic data are related to physical properties and seismic stratigraphy, as described previously in Barren, Larsen et al. (1989). Data from Sites 742 and 739 are illustrated in Figures 18 and 19, respectively.

\section{Site 740}

Site 740 is situated in the inner part of Prydz Bay, $30 \mathrm{~km}$ from the coast (Fig. 1). Only $12 \%$ of the glacial sequence was recovered, and it is mainly on the basis of drilling experience and seismic data that inferences can be made about the sediments. Seismically, the upper $56 \mathrm{~m}$ belongs to the flat-lying sequence.

The topmost Subunit IA ( 0 -about 15 mbsf) consists of diatom ooze with $75 \%-95 \%$ diatoms and minor radiolarians, silicoflagellates, clay, and silt (quartz and feldspar), but no gravel. The ooze is interbedded with structureless mud (silty, sandy clay) that contains up to $1 \%$ pebbles and coarse sand, but few diatoms. The sediments have a high water content. The biostratigraphic age range is late Pliocene to Holocene, but the sediment has the characteristics of Holocene material. Seismic data indicate that this unit is part of a thin, acoustically transparent sequence, lying conformably on the substrate and confined to a 2- to 3km-wide, west-east-trending coastal trough (Barron, Larsen, et al., 1989: p. 373). The subunit clearly was derived as a result of settling of the suspended biogenic component.

At $15 \mathrm{mbsf}$, Subunit IB with large boulders was encountered, and until 56 mbsf there was little further recovery except for a few broken clasts of granite and gneiss. The drilling properties of the sediments containing these boulders show a marked contrast with sediments above and below, and it is inferred that the bulk of the material is a boulderrich diamicton or conglomerate. Acoustically this horizon is also poorly defined, although it is characterized by high-amplitude reflections. The sediments form the flanks of a depression that lies adjacent to the shoreline, and a channel fill is inferred (Barron, Larsen, et al., 1989: p. 348).

Beneath this interval of almost no recovery, a red bed sequence of undetermined age was encountered (Turner, this volume). This probably represents the oldest part of the preglacial sedimentary fill in the Lambert Graben.

\section{Site 741}

Site 741 is located on the landward slope of Four Ladies Bank, 36 $\mathrm{km}$ northwest of Site 740 . As with Site 740 , recovery of the glacial part of the sequence was very poor, although similar drilling difficulties at the two sites suggest the same lithology. Seismically the glaciogenic part of this site (0-24 mbsf) belongs to the upper flat-lying sequence.

The top of the sequence at Site 741 (Unit I) is represented by $0.7 \mathrm{~m}$ of homogeneous diatom ooze, with approximately $75 \%$ diatoms, $20 \%$ clay, and silt-sized terrigenous material consisting mainly of clay miner- 
als, quartz, and feldspar, and also minor radiolarians, silicoflagellates, and sponge spicules. Several pebbles of crystalline rocks were noted. The sediment has a high water content, like that of Subunit IA at Site 740 .

Unit II (0.7-4.1 mbsf) is a soft, normally consolidated sandy mud with $10 \%-20 \%$ diatoms and a few shells. Both Units I and II have a Quaternary biostratigraphic age, and a Holocene age is considered most likely.

Unit III (4.I-24 mbsf) was very poorly recovered, but granite and gneissic rock fragments and the drilling behavior suggest it represents the same lithology as Subunit IB at Site 740 , namely a probably overconsolidated boulder-rich diamicton. Its age is unknown, but a Pleistocene age is suggested.

Seismic stratigraphic data do not show any resolution for the preceding part of the sequence. These sediments are underlain by preglacial silt, sand, and conglomerate of probable Albian age, belonging to Unit IV.

\section{Site $\mathbf{7 4 2}$}

Along with Site 739 , Site 742 provides the most complete record through the Prydz Bay glaciogenic sequence, although at neither Site was the base of the sequence penetrated. Site 742 was located in the middle part of the shelf, on the flanks of the Four Ladies Bank. The lithologies recovered are principally diamicts, separable into distinct units on the basis of stratification, compaction, and association with finergrained minor lithologies (Fig. 18). The downhole logging record does not include the upper $35 \mathrm{~m}$ nor the lower $29 \mathrm{~m}$ of the hole. The upper $173 \mathrm{~m}$ of this site belongs to the seismically defined flat-lying sequence, whereas the lower part (173-316 mbsf) belongs to the lower prograding unit. The upper prograding unit is not represented at this site.

Unit I (0-5.4 mbsf) comprises unconsolidated sediment overlying firm diamicton and is divided into two subunits. The uppermost Subunit IA consists of $7 \mathrm{~cm}$ of soupy olive diatomaceous sand-silt. Its principal constituents are quartz-feldspar sand and silt $(70 \%)$, diatoms $(20 \%)$, and clay $(10 \%)$. The coarse fraction includes minor amounts of opaque minerals, garnet, mica, and pyroxene. The age of this subunit is late Quaternary.

Subunit IB is a soft, gray, massive diamicton, the principal constituents of which (sand, silt, and clay) are present in roughly equal proportions. The gravel content varies from $5 \%$ to $10 \%$, and most clasts are less than $1 \mathrm{~cm}$ in diameter. Clast lithologies are predominantly highgrade metamorphic rocks, with minor sandstone. Sand and silt grains are similar in composition to those in Subunit IA. Up to $5 \%$ diatoms is present, as well as scattered radiolarians. Biostratigraphic data suggest a probable late Pliocene-Quaternary age. The lower boundary of the subunit is sharp but irregular.

Unit I matches precisely geotechnical Unit G1, which is represented by normally consolidated diamicton (i.e., it is lacking signs of loading; Solheim et al., this volume).

Unit II (5.4-115.2 mbsf) is a dark gray, homogeneous, massive diamictite with up to $15 \%$ gravel. Poor recovery characterizes this interval, and some cores contained only rock fragments. Most of the clasts are metamorphic rocks, but a few coaly shale and coal clasts are also present. The top of this unit has yielded a late Pliocene-Quaternary age.

The unit shows strong gradients in the physical properties and has indications of being overconsolidated (Solheim et al., this volume). Logging parameters (from $35 \mathrm{mbsf}$ ) are fairly constant and suggest a fairly uniform lithology through this unit (Ollier, this volume). Logging Unit IA matches lithological Unit II to within a few meters. Both lithological Units I and II show highly disrupted, high-amplitude reflections and no apparent internal stratification. All this is in keeping with the whole of Unit II as a homogeneous, massive diamictite.

Unit III (115.2-134.4 mbsf) is a variable unit, characterized by stratification and divided into four subunits. An 8.5-m-thick, dark gray, compacted, friable, massive to weakly stratified diamictite forms Subunit IIIA. The gravel content varies from $1 \%-10 \%$, and the interval is more rich in mud than Unit II. Lithologically, the clasts resemble those in the overlying units. The stratification has been affected by soft-sediment deformation. Minor mudstone layers also occur.

Subunit IIIB is represented by a 60 -cm-thick greenish gray diatomite. It is massive to weakly stratified. The diatom component of $70 \%$ is supplemented by sand and mud of terrigenous origin. The age is probably early Pliocene.

Subunit IIIC consists of $5.4 \mathrm{~m}$ of black, weakly stratified diamictite, in which the sand and gravel content strongly fluctuates, together with a poorly sorted, dark gray sandstone and a clayey siltstone horizon. The contacts between these beds are sharp and loaded.

Subunit IIID comprises one large boulder of gneiss, measuring 62 $\mathrm{cm}$ downcore, and several individual cobbles. No matrix was recovered, but a massive bouldery diamictite is suspected as having hosted these clasts.

Unit III is approximately matched by geotechnical Unit G3 and logging Unit IB. The physical properties are variable, demonstrating near normal consolidation, and internal disconformities are suspected. The logging data also demonstrate the varied lithological nature of this unit.

Unit IV (134.4-172.5 mbsf) is a dark gray to black, friable, massive diamictite, with $1 \%-7 \%$ gravel and slightly more than $1 \% C_{\text {org }}$. In places there is a weak, diffuse stratification on a scale of more than half a meter. The composition of the gravel, sand, and silt fractions resembles that of higher diamictite units, with the addition of a few carbonate-cemented sandstone clasts. Thin layers with minor $(10 \%)$ detrital carbonate occur toward the base. Toward the base, which is sharp and probably unconformable, the unit becomes paler, and probably incorporates material from the underlying unit. No age has been determined for this unit.

Unit IV approximately matches geotechnical Unit G4 and logging Unit II. The physical properties resemble those of Unit G2, indicating that the sediments are overconsolidated, and logging data indicate that the sediments are homogeneous. However, logging data show a marked change in composition toward Unit V.

Lithologic Units III and IV show more continuous reflections than does the upper part. There are three high-amplitude continuous reflections, representing the top, middle, and bottom of a low-high-low velocity zone. This is further indication of the lithological changes between 120 and 175 mbsf.

Unit $V(172.5-304.3 \mathrm{mbs})$ is a gray to olive gray, friable, homogeneous, massive diamictite with $1 \%-5 \%$ gravel. It differs from the overlying diamictites in having a lighter color, fewer gravel clasts, rare benthic shell fragments, and sporadic layers cemented by micritic carbonate. The gravel clasts appear to be more varied in composition, and include granite, amphibolite, and various types of gneiss, as well as intraclasts of diamictite. From rare calcareous nannofossils, an age of middle late Eocene to Oligocene was assigned to this unit. Greenish layers of glauconite and clay minerals, a few millimeters thick, occur sporadically.

The physical properties, downhole logging, and seismic data suggest that Unit $\mathrm{V}$ is a more complex unit than the recovered lithologies indicate. Geotechnically it has been divided into units G3, which shows normal consolidation, to G6 (also embracing lithologic Unit VI), which can be classified as overconsolidated, although this may be explained by the cementation observed at intervals in this unit. Logging data further show that this is a heterogeneous unit, with caved-in zones indicating variations in compaction and cementation. In particular, a sand unit (containing heavy minerals) is suggested at $215-230 \mathrm{mbsf}$, which lithologically was an interval of no recovery (Ollier, this volume).

Seismically, lithological Unit V can be divided into two contrasting parts. Large velocity variations occur in the upper $45 \mathrm{~m}$, although they generally increase downward, reflecting decreasing compaction and an absence of excess loading. Reflections indicate that the strata dip gently and thicken seaward, and that this 45 -m-thick upper part of lithological Unit V attains a maximum thickness between Sites 742 and 739 of about $300 \mathrm{~m}$. The records also show seaward stacking of reflectors (Cooper et al., this volume).

The lower $84 \mathrm{~m}$ of lithological Unit $\mathrm{V}$ is characterized by high-amplitude reflections of varying length and complexity, further lending support to the logging data, which show that other lithologies, particularly unlithified sand layers, are present in addition to the diamictite which was the only facies recovered. Some reflectors are traceable for 25-30 $\mathrm{km}$ through Sites 742 and 739 . The upper surface dips gently seaward, but the bottom is irregular and illustrates infilling to a depth of up to $150 \mathrm{~m}$ between these sites. Overall, the acoustic character suggests channelling or the presence of local sand bodies.

Unit VI (304.3-316.0 mbsf) is a varied unit that has been subdivided into three subunits. Subunit VIA comprises $3.2 \mathrm{~m}$ of gray, sandy mudstone that is well stratified on a centimeter scale and contains up to $7 \%$ gravel. The beds are well defined, although the precise contacts are normally diffuse or loaded. Some of the gravel clasts have a dropped-in appearance, including some mudstone intraclasts. A few millimeter-scale mudstone laminae appear to be graded. A few tiny shell casts and minor plant debris were noted, but they have not proved datable. 
Subunit VIB consists of $5.8 \mathrm{~m}$ of gray, homogeneous, massive diamictite with $1 \%-5 \%$ gravel up to about $1 \mathrm{~cm}$ in diameter. Compositionally, it resembles Subunit VIA, and the gravel is dominated by metamorphic lithologies, but with minor coal fragments. Toward the base, which shows weak stratification, a vague fold structure is apparent.

Subunit VIC is complex and occupies the bottom $2.7 \mathrm{~m}$ of the hole. It consists of (1) moderately well-sorted, quartz-feldspar whitish sand; (2) black carbonaceous siltstone similar to the sand but with $5 \%-10 \%$ organic debris; and (3) gray stratified diamictite with $1 \%$ gravel, $3 \%-$ $5 \%$ organic debris, and fragments of lignite. The subunit has undergone extensive soft-sediment deformation, with recumbent fold hinges, diapirically sorted sand segregations, and otherwise distorted bedding, all prominent. Brittle fractures in some sandy layers are also present.

Unit VI has not been differentiated from Unit V in geotechnical terms, and downhole logging failed to reach this unit. However, seismic data indicate that the boundary between these units is an unconformity. Unit VI is characterized by wavy reflections, discordant with the overlying strata, features that extend regionally over $75 \mathrm{~km}$, but which are represented by a variable thickness of sediment. At Site 742 this disturbed unit extends down to $415 \mathrm{mbsf}$, and so is $109 \mathrm{~m}$ thick. It reaches a maximum thickness seaward of the site of $200 \mathrm{~m}$, while landward it thins over a slight rise before thickening to $350 \mathrm{~m}$, and infilling a 40-km-wide trough beneath the central Prydz Bay shelf. The acoustic character is different from the overlying units, and shows a resemblance to the preglacial nonmarine sequence at Site 741. It further suggests sand layers, or more carbonaceous material in the sediments, as at Site 741 .

Beneath the preceding succession, additional seismic data show continuous and semicontinuous reflections, suggesting a well-layered sequence. The highly variable acoustic signature of the glaciogenic sediments is missing, and it is assumed that these are preglacial rocks of possible alluvial plain or shallow-marine origin.

\section{Site 739}

Located $30 \mathrm{~km}$ from the edge of the shelf and $140 \mathrm{~km}$ from land near Davis Station and the Amery Ice Shelf, Site 739 represents the most seaward of the holes drilled on the shelf. Seismically, the upper $170 \mathrm{~m}$ represent the flat-lying unit, the interval $170-310$ mbsf the upper prograding unit, and the remainder down to the total depth at 486 mbsf the lower prograding unit.

The bulk of the core recovered at Site 739 is diamict of remarkably uniform appearance. However, core recovery was only $35 \%$ in this hole and other lithologies may have been lost. On the basis of variations in bedding and the degree of compaction, five lithological units have been defined.

Unit I (0-24.1 mbsf) consists of soft, massive diamicton and sandy mud in colors ranging from olive to dark gray and dark grayish brown. The thickness of the soft layer varies from 2 to $13 \mathrm{~m}$ within $20 \mathrm{~m}$ horizontally. The diamicton and sandy mud differ only in the proportion of gravel clasts, being $1 \%-10 \%$ in the former and less than $1 \%$ in the latter. These clasts consist almost entirely of metamorphic rocks, especially gneisses with garnet and amphibole, biotite gneisses, and garnetiferous mica schists (Barron, Larsen, et al., 1989: p. 452). Quartz and feldspar make up the bulk of the finer fraction, but there is a variable proportion $(5 \%-35 \%)$ of diatoms. There is also $10 \%-25 \%$ clay minerals, minor amounts of radiolarians and foraminifers, and echinoderm fragments. Apart from the top few meters there was no recovery of this unit, but drilling difficulties indicated the presence of large boulders, probably forming part of a boulder diamicton. A biostratigraphic age of late Pliocene to Quaternary was assigned to this unit; the soft part is probably of late Pleistocene age, and supposed Holocene diatom oozes such as those that occur at other sites are absent.

Unit I equates approximately with geotechnical Unit G1, which indicates normal consolidation without any signs of excess loading. No logging data are available for this interval.

Unit II (24.1-173.6 mbsf) is dominated by dark gray to black, massive diamictite. Neither the top nor the bottom of the unit, nor the interval between 35 and $105 \mathrm{mbsf}$, was recovered, though drilling characteristics suggested a harder diamictite than in Unit I. Although compacted, the diamictite is friable and lacks cementation. The gravel content ranges mainly from $5 \%-20 \%$, as this is the part of Site 739 with the largest proportion of gravel as well as the largest clasts. Many clasts exceed the diameter of the core. The composition of the gravel is varied, with igneous (especially granite), metamorphic (gneiss, schist, quartzite, and amphibolite), and minor sedimentary (coaly shales, and sandstone) rocks represented. In the finer fractions the principal mineral constituents are quartz, feldspar, and clay minerals. The diamictite also has a relatively high diatom content, exceeding $20 \%$ in places, thereby imparting a greenish or olive tinge to the sediment. The age of this unit is defined paleontologically as late Miocene to early Pliocene.

Unit II spans approximately the same interval as geotechnical Unit G2, which is characterized by overconsolidation. Downhole logging data show Unit II to consist of two distinct logging Units I and II, the first of which (down to 110 mbsf) shows constant logging characteristics, suggestive of diamictite. Hard and soft zones are reflected in cave-in variations. The hard parts are boulders, which being igneous and metamorphic give a strongly radioactive signal, whereas the softer parts represent diamictite matrix-dominated parts of the core. Logging Unit II shows an abrupt decrease in porosity and increase in velocity indicating, as do the geotechnical properties, that the sediment is overconsolidated. The presence of sand layers (not recovered) is also suspected for this part of the section.

Lithological Units I and II have a sequence of high-frequency, discontinuous reflections of flat-lying attitude. High-velocity layers are related to compaction events.

Unit III (173.6-267.2 mbsf) comprises three subunits defined on the basis of bedding characteristics, although the contacts between the subunits have not been recovered. Subunit IIIA comprises $19.3 \mathrm{~m}$ of moderately well- to weakly-stratified diamictite and minor mudstone. The bedding, on a scale of $10-100 \mathrm{~cm}$, is marked principally by color changes between dark olive gray for the bulk of the sediment and olive gray for the remaining, finer-grained, diatom-rich sediment. The gravel content varies considerably over short distances, ranging overall from $3 \%-10 \%$, although the more diatomaceous parts may have less than $1 \%$. Intraclasts of diamictite were noted in the lower part of the subunit. The mineral composition is dominated by quartz and feldspar $(50 \%-74 \%)$, with the remainder clay and diatoms. The stratification is frequently steeply inclined and shows indications of soft-sediment folding. Graded bedding was noted, and there is evidence of bioturbation. Where the core was fractured, such as along bedding surfaces, slickenside striations can be observed.

Subunit IIIB occurs in an interval of poor recovery amounting to 5.2 $\mathrm{m}$ in thickness. It is a dark gray, massive, diatomaceous sandy mudstone with less than $1 \%$ or no gravel. It lacks bedding but is strongly fractured. It is composed chiefly of quartz, feldspar, clay, and up to $30 \%$ diatoms. Minor amounts of sponge spicules, silicoflagellates, and broken mollusk shells also occur.

Subunit IIIC (69.1 m thick) consists of alternating beds of massive and weakly stratified diamictite and minor laminated siltstone. The massive diamictite is dark greenish gray to dark gray and black, occurring in decimeter- to meter-thick beds. It contains up to $10 \%$ gravel. Shell fragments and complete shells of scaphopods are thinly scattered through these beds, and there is strong evidence of burrowing. The stratified diamictite is similar, but is interbedded with millimeter- to centimeter-thick diffuse greenish gray layers with a diatom content of up to $40 \%$ and fewer gravel clasts. The layers show signs of slumping, but are not disaggregated. Contacts with massive diamictite beds are both sharp and gradational, and some show signs of loading. Stratified diamictite also contains entire shells and broken shell fragments, and burrowing is in evidence. A good dropstone structure was observed in one clast-poor bed. The diamictites contain a wide variety of basement clasts, including several varieties of gneiss. Sedimentary clasts are uncommon, with only coal and limestone identified. Of the finer fractions, quartz and feldspar are dominant (up to $75 \%$ ), with clay and diatoms also prominent. Of the components occurring in trace quantities, palagonite, silicoflagellates, calcareous nannofossils, and sponge spicules are the most significant. A minor lithology, occurring at five levels, is laminated mudstone of apparent rhythmic character.

Unit III has a biostratigraphic age ranging from late Eocene to early Oligocene; however, Sr-isotopic determinations on shells (Thierstein et al., this volume) indicate an age in the range 23-28 Ma (late Oligocene). Further work is underway to resolve this conflict. Its geotechnical, logging, and seismic characteristics are discussed in the following section.

Unit IV (267.2-315.7 mbsf) is a dark gray, massive diamictite, separated from Unit III by a sharp erosional contact. The gravel content ranges from $1 \%$ to $10 \%$, but averages about $3 \%$. Clast lithologies are varied, but are predominantly basement gneiss and granite; some diamictite clasts occur. Sandier patches and faint diffuse bedding were identified at a few levels. Small shell fragments occur sporadically, and at $267.4 \mathrm{mbsf}$ an intact gastropod was recovered. The finer fractions are dominated by quartz, feldspar, and clay minerals, with the diatom con- 
tent varying from trace amounts to $20 \%$. Minor silicoflagellates, radiolarians, and nannofossils also occur in trace amounts. The age of this unit based on diatom stratigraphy is late Eocene-early Oligocene, but a single $\mathrm{Sr}$ isotope value of $29 \mathrm{Ma}$ indicates a late Oligocene age.

Lithological Units III and IV are slightly indurated. They are equated with geotechnical Units G3 to G6, which show variations in the degree of compaction in the sediments, related to a succession of discrete loading events that overconsolidated some horizons but not others. Logging Unit III embraces lithological Unit III and the uppermost part of Unit IV and demonstrates highly variable parameters that reflect lithological variations with at least two highly compacted units. Compared with the overlying unit there is a sharp reduction in radioactivity, which agrees with a change in overall composition (Ollier, this volume).

Lithological Units III and IV belong to the upper, more steeply inclined, part of the prograding unit in the outer Prydz Bay shelf. This shows distinct dipping reflections, some of which are continuous for $150-400 \mathrm{~m}$, as well as signs of internal deformation and slumping.

Unit $V(315.7-486.8 \mathrm{mbs} f)$ does not show any clear boundary with Unit IV; it is defined on the basis of the first appearance downcore of carbonate-cemented layers. The unit consists of dark gray, dark greenish gray, and dark olive gray massive diamictite, although in lighter tones than the overlying diamictites. The gravel content is lower than in Unit IV, averaging around $2 \%$ but reaching $5 \%$ locally. The clasts are also smaller on average, but they appear to be more variable than in the overlying units. The clasts are mainly of gneiss and granite, but also include felsite, schist, quartzite, diamictite, coal, shale, and different colored sandstones. Local segregations of larger clasts occur, and there are pockets and stringers of quartz granules. Long-axis alignment of a few grains at an angle to the horizontal and a slump structure near the base are the only indications of stratification. Carbonate-cemented layers occur at four levels in this unit, one of which is $35 \mathrm{~cm}$ thick. They are pale colored and harder than the adjacent diamictite, which only has $0.4 \%-2 \%$ carbonate. Diatoms and nannofossils occur in trace amounts. A few poorly preserved shell fragments and sponge spicules occur above 400 mbsf. Age constraints are poor in this unit; nannofossils suggest merely a (?)middle Eocene to Oligocene age (Thierstein and Wei, this volume), but from the overlying unit we can say that it is at least early Oligocene in age.

Lithological Unit V is equivalent to geotechnical Units G7 and G8, which are normally consolidated and provide no indication of any major loading events in this part of the succession. Downhole logging Unit IV, which covers lithological Unit V and part of Unit IV, depicts numer- ous porous layers that are interpreted as sand or gravel. None of these layers was recovered, but the poor recovery would support this interpretation.

Seismically, lithological Unit V belongs to the lower part of the prograding sequence, and has gently dipping, weak, continuous reflections that appear to come from low-velocity layers $2-5 \mathrm{~m}$ thick. These layers are probably unlithified sands and maintain an even thickness for 10-15 $\mathrm{km}$ along the Prydz Bay transect, suggesting an outer continental shelf environment.

\section{Site $\mathbf{7 4 3}$}

Site 743 is situated on the upper continental slope in about $1000 \mathrm{~m}$ of water, above the level at which the slope morphology appears from the seismic record to be dominated by slumps. The site was occupied to examine the facies and sedimentary processes on a continental slope associated with a shelf dominated by glaciogenic sediments, as a possible model for Site 739 Units III and IV, as well as to ascertain whether Quaternary glaciation reached the shelf edge. Again, however, only poor recovery $(22 \%)$ was achieved.

Unit I (0-0.5 mbsf) is a moderately well-sorted loose sand, predominantly of quartz and feldspar, but also metamorphic rock fragments, mica, and garnet. The upper part of this sand horizon is mixed (probably as a result of drilling) with diatom ooze, that may have lain on top; up to $50 \%$ diatoms are present. The sand contains a few pebbles of gneiss, and near the base of the unit is a layer containing $20 \%$ of sizesorted foraminifers.

Unit II (0.5-15.8 mbsf) is a soft, homogeneous, structureless clayey silt or silty clay, with up to $1 \%$ gravel. It is interbedded with loose gravelly sand with foraminifers, and the lithological contacts are sharp.

Unit III (15.8-98.1 mbsf) appears to be a massive diamicton (clayey silt with sand and gravel), although little more than assemblages of stones were recovered. Where diamicton was recovered, it was observed to be structureless and stiff, containing $5 \%-25 \%$ gravel. The clasts cover the entire range of shapes, but $85 \%$ fall into the subangular and subrounded classes; many are faceted. They include a wide variety of high-grade metamorphic rocks and minor sandstone, and a few have weathering rinds. The sand and silt fraction is dominated by quartz and feldspar $(70 \%)$ and clay minerals $(25 \%)$; pyroxene, amphibole, and mica occur as accessory minerals.

Unit $\mathrm{I}$ is inferred to be of Holocene age and the remainder Pleistocene, although the best biostratigraphic age estimate is late Pliocene to Quaternary. 

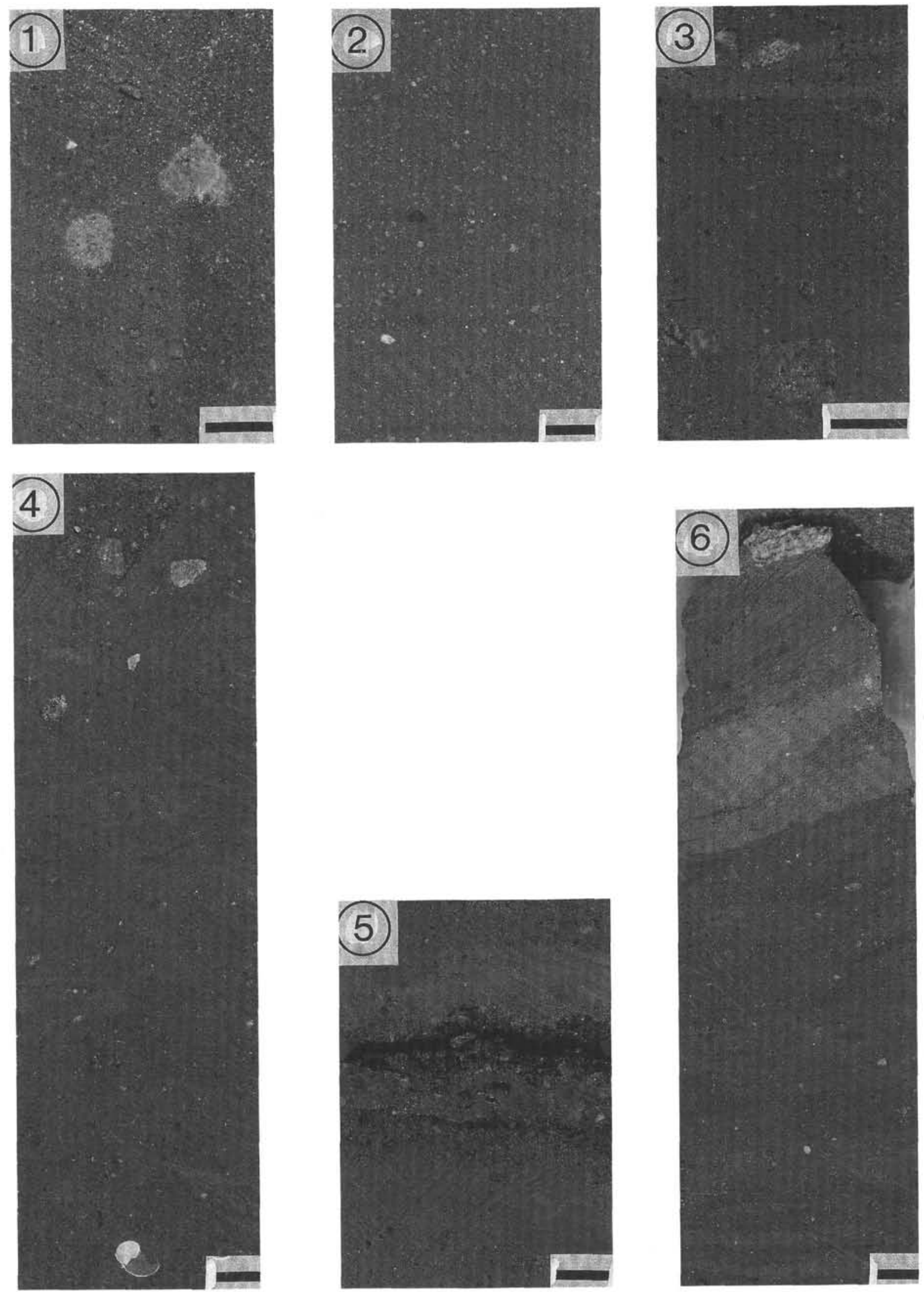

Plate 1. Typical diamictite facies from sites 739 and 742 . Scale bar represents $1 \mathrm{~cm}$. 1. Massive diamictite (Dm), Core $119-739 \mathrm{C}-4 \mathrm{R}-1,18-25 \mathrm{~cm}$. 2. Massive diamictite $(\mathrm{Dm})$, Core $119-742 \mathrm{~A}-21 \mathrm{R}-1,54-73 \mathrm{~cm}$. 3. Weakly stratified diamictite (Dw), Core $119-742 \mathrm{~A}-14 \mathrm{R}-3.64-70 \mathrm{~cm}$. 4. Weakly stratified diamictite with mottling caused by bioturbation, with a dropped-in diamictite pellet (top) and bivalve shell (bottom). Core 119-739C-30R-1, 93-110 cm. 5. Gravel lag deposit, Core 119-739C-30R-3, 90-98 cm. 6. Well-stratified diamictite (Ds), Core 119-739C-29R-3, 123-140 cm. 


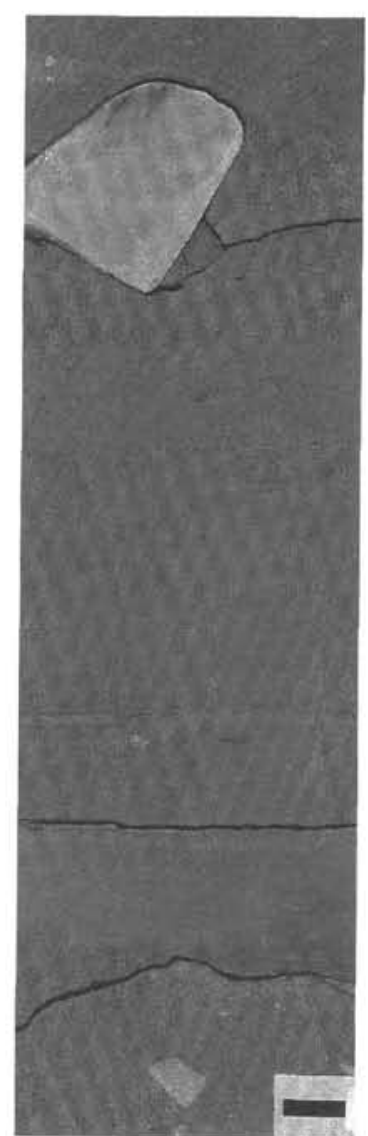

1

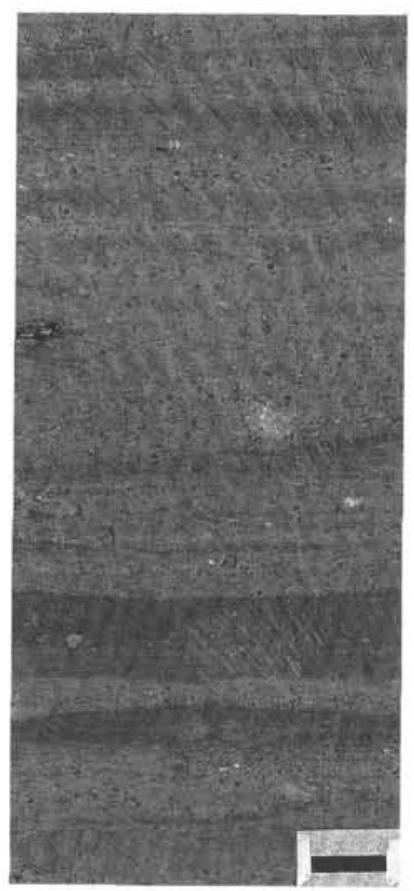

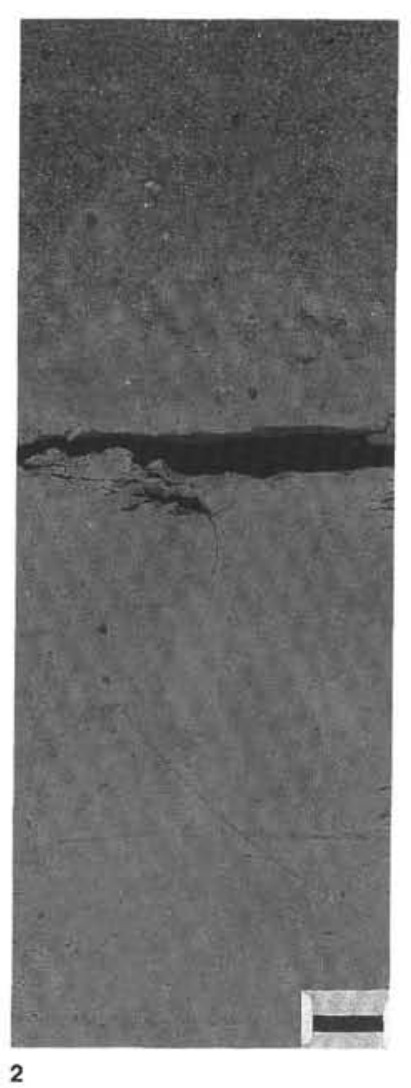

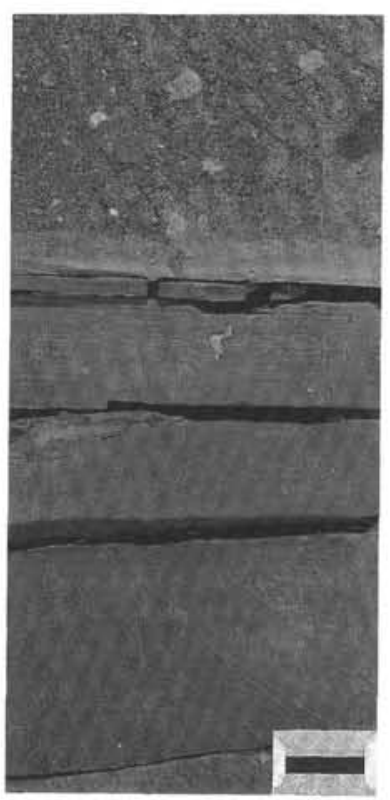

4

Plate 2. Minor facies from Sites 739 and 742 . 1. Mudstone (Ms-Mm) with dropstone in Unit III, overlying eroded diamictite at top of Unit IV, Core 119-739C-34R-3, 68-87 cm. 2. Diatomite (DO) with terrigenous component overlain by diatomaceous muddy sand, Core 119-742A-15R-4, 15$30 \mathrm{~cm}$. 3. Stratified gravelly sandy mudstone (GMs) forming poorly developed couplets, Core 119-742A-33R-6, 60-72 cm. 4. Contact between massive diamictite of Unit V and rhythmite (R) and massive mudstone (Mm) at top of Unit VI, Core 119-742A-33R-6, 5-15 cm. Scale bars represent 1 $\mathrm{cm}$. 


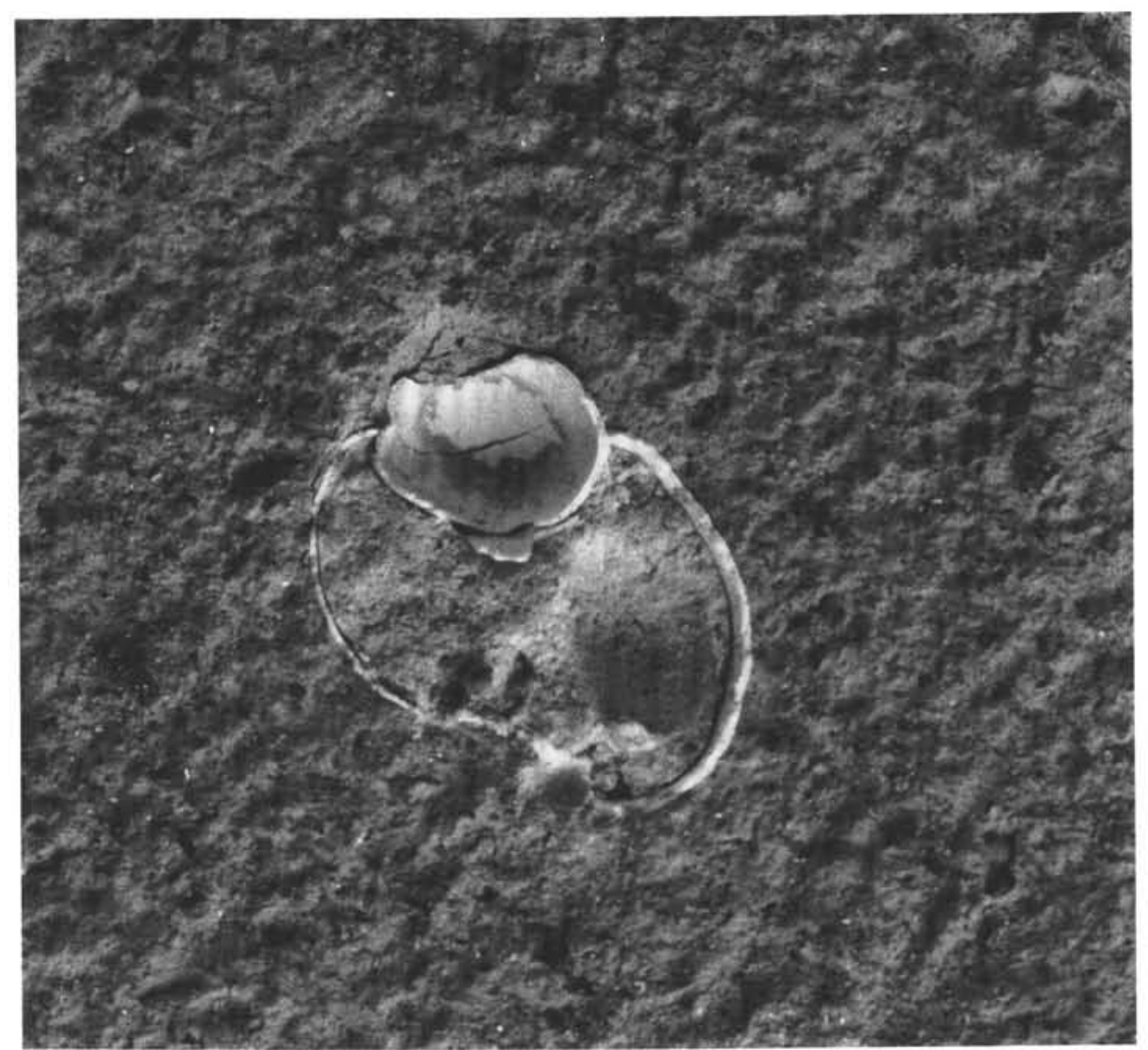

Plate 3. Thin, complete gastropod shell containing unlithified diatom ooze, enclosed in diamicton from Site 739, 223 mbsf (Subunit IIIC, upper prograding unit). The shell is Natacid (Amauropsis?) and about $7 \mathrm{~mm}$ across. The ooze contains a diverse diatom flora. These observations suggest redeposition of diatom ooze and diamicton by debris flow on the continental slope, rather than direct deposition from ice. 

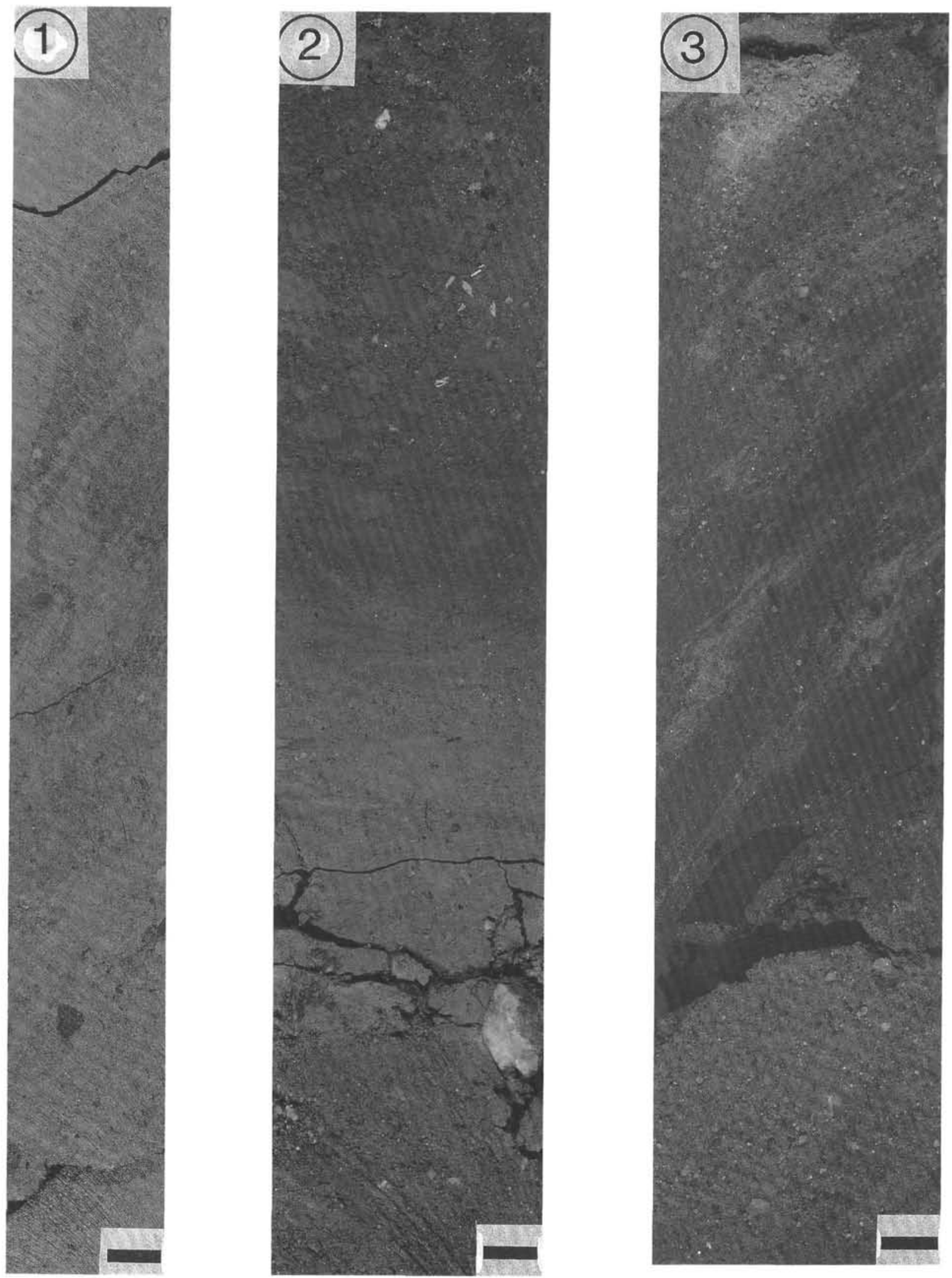

Plate 4. Evidence of reworking in diamictite facies. 1. Slumping of stratified diamictite (Ds), Core 119-739C-33R-3, 45-90 cm. 2. Lower part of a gravity-flow horizon with intraclasts of the subjacent mudstone (which shows evidence of having been ripped up) and massive diamictite (Dm) at the base, Core 119-742A-15R-2, 100-122 cm. 3. Highly contorted diamictite (Dw and Ms) with diffuse sand pockets from base of Hole 742A, interpreted as possible glaciotectonic deformation, Core 119-742A-34R-6, 20-40 cm. Scale bars represent $1 \mathrm{~cm}$. 